\title{
Interventions for cutaneous molluscum contagiosum (Review)
}

van der Wouden JC, van der Sande R, Kruithof EJ, Sollie A, van Suijlekom-Smit LWA, Koning S

van der Wouden JC, van der Sande R, Kruithof EJ, Sollie A, van Suijlekom-Smit LWA, Koning S.

Interventions for cutaneous molluscum contagiosum.

Cochrane Database of Systematic Reviews 2017, Issue 5. Art. No.: CD004767.

DOI: 10.1002/14651858.CD004767.pub4.

www.cochranelibrary.com 
TABLE OF CONTENTS

HEADER

ABSTRACT

PLAIN LANGUAGE SUMMARY

SUMMARY OF FINDINGS

BACKGROUND

OBJECTIVES

METHODS

RESULTS

Figure 1.

Figure 2.

Figure 3.

DISCUSSION

AUTHORS' CONCLUSIONS

ACKNOWLEDGEMENTS

REFERENCES

CHARACTERISTICS OF STUDIES

DATA AND ANALYSES

Analysis 1.1. Comparison 1 Topical: $5 \%$ imiquimod versus vehicle, Outcome 1 Primary outcome: short-term clinical cure (up to 3 months after start of treatment).

Analysis 1.2. Comparison 1 Topical: $5 \%$ imiquimod versus vehicle, Outcome 2 Secondary outcome: medium-term clinical cure (after 3 and up to 6 months after start of treatment).

Analysis 1.3. Comparison 1 Topical: 5\% imiquimod versus vehicle, Outcome 3 Secondary outcome: long-term clinical cure (> 6 months after start of treatment).

Analysis 1.4. Comparison 1 Topical: 5\% imiquimod versus vehicle, Outcome 4 Secondary outcome: short-term clinical improvement (up to 3 months after start of treatment).

Analysis 1.5. Comparison 1 Topical: $5 \%$ imiquimod versus vehicle, Outcome 5 Secondary outcome: medium-term clinical improvement (after 3 and up to 6 months after start of treatment).

Analysis 1.6. Comparison 1 Topical: $5 \%$ imiquimod versus vehicle, Outcome 6 Secondary outcome: recurrence. ..................... Analysis 1.7. Comparison 1 Topical: $5 \%$ imiquimod versus vehicle, Outcome 7 Secondary outcome: any side effect. ................ Analysis 1.8. Comparison 1 Topical: $5 \%$ imiquimod versus vehicle, Outcome 8 Secondary outcome: application site reaction. ... Analysis 1.9. Comparison 1 Topical: $5 \%$ imiquimod versus vehicle, Outcome 9 Secondary outcome: severe application site reaction.

Analysis 2.1. Comparison 2 Topical: 5\% imiquimod versus cryospray, Outcome 1 Primary outcome: short-term clinical cure (up to 3 months after start of treatment).

Analysis 2.2. Comparison 2 Topical: $5 \%$ imiquimod versus cryospray, Outcome 2 Secondary outcome: medium-term clinical cure (after 3 and up to 6 months after start of treatment).

Analysis 2.3. Comparison 2 Topical: $5 \%$ imiquimod versus cryospray, Outcome 3 Secundary outcome: recurrence.

Analysis 3.1. Comparison 3 Topical: $5 \%$ imiquimod versus $10 \%$ potassium hydroxide, Outcome 1 Primary outcome: short-term clinical cure (up to 3 months after start of treatment).

Analysis 3.2. Comparison 3 Topical: $5 \%$ imiquimod versus $10 \%$ potassium hydroxide, Outcome 2 Secondary outcome: any side effect.

Analysis 4.1. Comparison 4 Topical: $10 \%$ lemon myrtle oil versus vehicle, Outcome 1 Primary outcome: short-term clinical cure (up to 3 months after start of treatment).

Analysis 5.1. Comparison 5 Topical: 10\% benzoyl peroxide cream versus $0.05 \%$ tretinoin cream, Outcome 1 Primary outcome: short-term clinical cure (up to 3 months after start of treatment).

Analysis 6.1. Comparison 6 Topical: 10\% potassium hydroxide versus saline, Outcome 1 Primary outcome: short-term clinical cure (up to 3 months after start of treatment).

Analysis 7.1. Comparison 7 Topical: $2.5 \%$ potassium hydroxide versus 5\% potassium hydroxide, Outcome 1 Primary outcome: short-term clinical cure (up to 3 months after start of treatment).

Analysis 7.2. Comparison 7 Topical: $2.5 \%$ potassium hydroxide versus $5 \%$ potassium hydroxide, Outcome 2 Secondary outcome: short-term improvement (up to 3 months after start of treatment).

Analysis 8.1 . Comparison 8 Topical: $10 \%$ potassium hydroxide versus $14 \%$ salicylic acid $+14 \%$ lactic acid, Outcome 1 Primary outcome: short-term clinical cure (up to 3 months after start of treatment). 
Analysis 9.1. Comparison 9 Topical: 10\% potassium hydroxide versus curettage, Outcome 1 Primary outcome: short-term clinical cure (up to 3 months after start of treatment).

Analysis 10.1. Comparison 10 Topical $10 \%$ potassium hydroxide versus cryotherapy, Outcome 1 Primary outcome: short-term clinical cure (up to 3 months after start of treatment).

Analysis 10.2. Comparison 10 Topical 10\% potassium hydroxide versus cryotherapy, Outcome 2 Secondary outcome: shortterm clinical improvement (up to 3 months after start of treatment).

Analysis 11.1. Comparison 11 Topical: 10\% povidone iodine versus 50\% salicylic acid plaster, Outcome 1 Primary outcome: short-term clinical cure (up to 3 months after start of treatment).

Analysis 12.1. Comparison 12 Topical: $10 \%$ povidone iodine alone versus $10 \%$ povidone iodine and $50 \%$ salicylic plaster, Outcome 1 Primary outcome: short-term clinical cure (up to 3 months after start of treatment).

Analysis 13.1. Comparison 13 Topical: $10 \%$ povidone iodine and $50 \%$ salicylic acid plaster versus $50 \%$ salicylic plaster alone, Outcome 1 Primary outcome: short-term clinical cure (up to 3 months after start of treatment).

Analysis 14.1. Comparison 14 Topical: $0.7 \%$ cantharidin versus vehicle, Outcome 1 Primary outcome: short-term clinical cure (up to 3 months after start of treatment)..

Analysis 15.1. Comparison 15 Topical: $5 \%$ sodium nitrite in $5 \%$ salicylic acid versus $5 \%$ salicylic acid alone, Outcome 1 Primary outcome: short-term clinical cure (up to 3 months after start of treatment).

Analysis 16.1. Comparison 16 Topical: $12 \%$ salicylic acid versus $70 \%$ alcohol, Outcome 1 Secondary outcome: medium-term clinical cure (after 3 and up to 6 months after start of treatment).

Analysis 17.1. Comparison 17 Topical: 12\% salicylic acid versus 10\% phenol/70\% alcohol, Outcome 1 Secondary outcome: medium-term clinical cure (after 3 and up to 6 months after start of treatment).

Analysis 18.1. Comparison 18 Topical: $14 \%$ salicylic acid + 14\% lactic acid versus curettage, Outcome 1 Primary outcome: shortterm clinical cure (up to 3 months after start of treatment).

Analysis 19.1. Comparison 19 Topical: $70 \%$ alcohol versus 10\% phenol/70\% alcohol, Outcome 1 Secondary outcome: mediumterm clinical cure (after 3 and up to 6 months after start of treatment).

Analysis 20.1. Comparison 20 Topical: iodine versus tea tree oil, Outcome 1 Primary outcome: short-term clinical cure (up to 3 months after start of treatment).

Analysis 20.2. Comparison 20 Topical: iodine versus tea tree oil, Outcome 2 Secondary outcome: improvement (up to 3 months after start of treatment).

Analysis 21.1. Comparison 21 Topical: iodine versus tea tree oil combined with iodine, Outcome 1 Primary outcome: short-term clinical cure (up to 3 months after start of treatment).

Analysis 21.2. Comparison 21 Topical: iodine versus tea tree oil combined with iodine, Outcome 2 Secondary outcome: improvement (up to 3 months after start of treatment).

Analysis 22.1. Comparison 22 Topical: tea tree oil versus tea tree oil combined with iodine, Outcome 1 Primary outcome: shortterm clinical cure (up to 3 months after start of treatment).

Analysis 22.2. Comparison 22 Topical: tea tree oil versus tea tree oil combined with iodine, Outcome 2 Secondary outcome: improvement (up to 3 months after start of treatment).

Analysis 23.1. Comparison 23 Systemic: cimetidine versus placebo, Outcome 1 Secondary outcome: medium-term clinical cure (after 3 months and up to 6 months after start of treatment).

Analysis 23.2. Comparison 23 Systemic: cimetidine versus placebo, Outcome 2 Secondary outcome: medium-term improvement (after 3 months and up to 6 months after start of treatment).

Analysis 24.1. Comparison 24 Systemic: calcarea carbonica versus placebo, Outcome 1 Primary outcome: short-term clinical cure (up to 3 months after start of treatment).

ADDITIONAL TABLES

APPENDICES

WHAT'S NEW

HISTORY

CONTRIBUTIONS OF AUTHORS

DECLARATIONS OF INTEREST

SOURCES OF SUPPORT

DIFFERENCES BETWEEN PROTOCOL AND REVIEW

INDEX TERMS 
[Intervention Review]

\section{Interventions for cutaneous molluscum contagiosum}

Johannes C van der Wouden ${ }^{1}$, Renske van der Sande ${ }^{2}$, Emma J Kruithof ${ }^{1}$, Annet Sollie ${ }^{3}$, Lisette WA van Suijlekom-Smit ${ }^{4}$, Sander Koning ${ }^{2}$

1Department of General Practice and Elderly Care Medicine, Amsterdam Public Health Research Institute, VU University Medical Center, Amsterdam, Netherlands. ${ }^{2}$ Department of General Practice, Erasmus Medical Center, Rotterdam, Netherlands. ${ }^{3}$ Maison Medical Bel Air, Carpentras, France. ${ }^{4}$ Department of Paediatrics, Paediatric Rheumatology, Erasmus Medical Center - Sophia Children's Hospital, Rotterdam, Netherlands

Contact address: Johannes C van der Wouden, Department of General Practice and Elderly Care Medicine, Amsterdam Public Health Research Institute, VU University Medical Center, PO Box 7057, Amsterdam, 1007 MB, Netherlands. j.vanderwouden@vumc.nl.

Editorial group: Cochrane Skin Group.

Publication status and date: New search for studies and content updated (conclusions changed), published in Issue 5, 2017.

Citation: van der Wouden JC, van der Sande R, Kruithof EJ, Sollie A, van Suijlekom-Smit LWA, Koning S. Interventions for cutaneous molluscum contagiosum. Cochrane Database of Systematic Reviews 2017, Issue 5. Art. No.: CD004767. DOI: 10.1002/14651858.CD004767.pub4.

Copyright ( 2017 The Cochrane Collaboration. Published by John Wiley \& Sons, Ltd.

\section{A B S T R A C T}

\section{Background}

Molluscum contagiosum is a common skin infection that is caused by a pox virus and occurs mainly in children. The infection usually resolves within months in people without immune deficiency, but treatment may be preferred for social and cosmetic reasons or to avoid spreading the infection. A clear evidence base supporting the various treatments is lacking.

This is an update of a Cochrane Review first published in 2006, and updated previously in 2009.

\section{Objectives}

To assess the effects of specific treatments and management strategies, including waiting for natural resolution, for cutaneous, non-genital molluscum contagiosum in people without immune deficiency.

\section{Search methods}

We updated our searches of the following databases to July 2016: the Cochrane Skin Group Specialised Register, CENTRAL, MEDLINE, Embase, and LILACS. We searched six trial registers and checked the reference lists of included studies and review articles for further references to relevant randomised controlled trials. We contacted pharmaceutical companies and experts in the field to identify further relevant randomised controlled trials.

\section{Selection criteria}

Randomised controlled trials of any treatment of molluscum contagiosum in people without immune deficiency. We excluded trials on sexually transmitted molluscum contagiosum and in people with immune deficiency (including those with HIV infection).

\section{Data collection and analysis}

Two review authors independently selected studies, assessed methodological quality, and extracted data from selected studies. We obtained missing data from study authors where possible.

\section{Main results}

We found 11 new studies for this update, resulting in 22 included studies with a total of 1650 participants. The studies examined the effects of topical ( 20 studies) and systemic interventions ( 2 studies). 
Among the new included studies were the full trial reports of three large unpublished studies, brought to our attention by an expert in the field. They all provided moderate-quality evidence for a lack of effect of $5 \%$ imiquimod compared to vehicle (placebo) on short-term clinical cure (4 studies, 850 participants, 12 weeks after start of treatment, risk ratio (RR) 1.33, 95\% confidence interval (CI) 0.92 to 1.93 ), mediumterm clinical cure (2 studies, 702 participants, 18 weeks after start of treatment, RR $0.88,95 \% \mathrm{Cl} 0.67$ to 1.14 ), and long-term clinical cure ( 2 studies, 702 participants, 28 weeks after start of treatment, RR $0.97,95 \% \mathrm{Cl} 0.79$ to 1.17 ). We found similar but more certain results for short-term improvement (4 studies, 850 participants, 12 weeks after start of treatment, RR $1.14,95 \% \mathrm{Cl} 0.89$ to 1.47 ; high-quality evidence). For the outcome 'any adverse effect', we found high-quality evidence for little or no difference between topical $5 \%$ imiquimod and vehicle (3 studies, 827 participants, RR $0.97,95 \% \mathrm{Cl} 0.88$ to 1.07), but application site reactions were more frequent in the groups treated with imiquimod (moderate-quality evidence): any application site reaction ( 3 studies, 827 participants, $\mathrm{RR} 1.41,95 \% \mathrm{Cl} 1.13$ to 1.77 , the number needed to treat for an additional harmful outcome (NNTH) was 11); severe application site reaction (3 studies, 827 participants, RR 4.33 , $95 \% \mathrm{Cl} 1.16$ to 16.19 , NNTH over 40 ).

For the following 11 comparisons, there was limited evidence to show which treatment was superior in achieving short-term clinical cure (low-quality evidence): $5 \%$ imiquimod less effective than cryospray ( 1 study, 74 participants, $\mathrm{RR} 0.60,95 \% \mathrm{Cl} 0.46$ to 0.78 ) and $10 \%$ potassium hydroxide ( 2 studies, 67 participants, RR $0.65,95 \% \mathrm{Cl} 0.46$ to 0.93 ); $10 \%$ Australian lemon myrtle oil more effective than olive oil (1 study, 31 participants, RR $17.88,95 \% \mathrm{Cl} 1.13$ to 282.72 ); $10 \%$ benzoyl peroxide cream more effective than $0.05 \%$ tretinoin ( 1 study, 30 participants, RR $2.20,95 \% \mathrm{Cl} 1.01$ to 4.79 ); $5 \%$ sodium nitrite co-applied with $5 \%$ salicylic acid more effective than $5 \%$ salicylic acid alone (1 study, 30 participants, RR 3.50, 95\% Cl 1.23 to 9.92); and iodine plus tea tree oil more effective than tea tree oil (1 study, 37 participants, RR $0.20,95 \% \mathrm{Cl} 0.07$ to 0.57 ) or iodine alone (1 study, 37 participants, RR $0.07,95 \% \mathrm{Cl} 0.01$ to 0.50 ). Although there is some uncertainty, $10 \%$ potassium hydroxide appears to be more effective than saline ( 1 study, 20 participants, RR 3.50, 95\% $\mathrm{Cl} 0.95$ to 12.90 ); homeopathic calcarea carbonica appears to be more effective than placebo ( 1 study, 20 participants, RR $5.57,95 \% \mathrm{Cl} 0.93$ to 33.54 ); $2.5 \%$ appears to be less effective than $5 \%$ solution of potassium hydroxide ( 1 study, 25 participants, $\mathrm{RR} 0.35,95 \% \mathrm{Cl} 0.12$ to 1.01 ); and $10 \%$ povidone iodine solution plus $50 \%$ salicylic acid plaster appears to be more effective than salicylic acid plaster alone (1 study, 30 participants, RR $1.43,95 \%$ $\mathrm{Cl} 0.95$ to 2.16$)$.

We found no statistically significant differences for other comparisons (most of which addressed two different topical treatments). We found no randomised controlled trial evidence for expressing lesions or topical hydrogen peroxide.

Study limitations included no blinding, many dropouts, and no intention-to-treat analysis. Except for the severe application site reactions of imiquimod, none of the evaluated treatments described above were associated with serious adverse effects (low-quality evidence). Among the most common adverse events were pain during application, erythema, and itching. Included studies of the following comparisons did not report adverse effects: calcarea carbonica versus placebo, $10 \%$ povidone iodine plus $50 \%$ salicylic acid plaster versus salicylic acid plaster, and $10 \%$ benzoyl peroxide versus $0.05 \%$ tretinoin.

We were unable to judge the risk of bias in most studies due to insufficient information, especially regarding concealment of allocation and possible selective reporting. We considered five studies to be at low risk of bias.

\section{Authors' conclusions}

No single intervention has been shown to be convincingly effective in the treatment of molluscum contagiosum. We found moderatequality evidence that topical $5 \%$ imiquimod was no more effective than vehicle in terms of clinical cure, but led to more application site reactions, and high-quality evidence that there was no difference between the treatments in terms of short-term improvement. However, high-quality evidence showed a similar number of general side effects in both groups. As the evidence found did not favour any one treatment, the natural resolution of molluscum contagiosum remains a strong method for dealing with the condition.

\section{PLAIN LANGUAGE SUMMARY}

\section{Treatments for molluscum contagiosum, a common viral skin infection in children}

\section{Review question}

We reviewed the evidence for the effect of any treatment on the common viral skin infection molluscum contagiosum. We excluded people with a repressed immune system or sexually transmitted molluscum contagiosum.

\section{Background}

Molluscum contagiosum in healthy people is a self limiting, relatively harmless viral skin infection. It mainly affects children and adolescents and is rare in adults. It occurs worldwide, but seems much more frequent in geographic areas with warm climates. Molluscum contagiosum usually presents as single or multiple pimples filled with an oily substance. People may seek treatment for social and cosmetic reasons and because of concerns about spreading the disease to others. Treatment is intended to speed up the healing process.

\section{Study characteristics}

We searched the literature to July 2016. We included 22 trials (total of 1650 participants). Twenty of the studies evaluated topical treatment, and two studies evaluated treatment taken by mouth (oral). Comparisons included physical therapies, as well as topical and 
oral treatments. Most studies were set in hospital outpatient or emergency departments, and were performed in North America, the UK, Asia, or South America. Participants were of both sexes and were mainly children or young adults. Follow-up duration varied from 3 to 28 weeks after randomisation. Only five studies had longer than 3 months' follow-up.

Five studies reported commercial funding, three studies obtained medication for free from pharmaceutical companies, 12 studies did not mention the source of funding, one study reported charity funding, and one study reported they had had no financial support.

\section{Key results}

We found that many common treatments for molluscum, such as physical destruction, have not been adequately evaluated. Some of the included treatments are not part of standard practice.

We found moderate-quality evidence that topical $5 \%$ imiquimod is probably no more effective than vehicle (i.e. the same cream but without imiquimod) in achieving short-, medium-, and long-term clinical cure. High-quality (and thus more certain) evidence showed that topical $5 \%$ imiquimod is no better than placebo at improving molluscum up to three months after the start of treatment.

High-quality evidence showed that $5 \%$ imiquimod differed little or not at all in the number of side effects compared to vehicle. However, moderate-quality evidence suggests that there are probably more application site reactions when using topical $5 \%$ imiquimod compared with vehicle.

Low-quality evidence, based on one or two mostly small studies, revealed the following results for the outcome short-term clinical cure: $5 \%$ imiquimod less effective than cryospray or $10 \%$ potassium hydroxide; $10 \%$ Australian lemon myrtle oil more effective than olive oil; $10 \%$ benzoyl peroxide cream more effective than $0.05 \%$ tretinoin; $5 \%$ sodium nitrite co-applied with $5 \%$ salicylic acid more effective than $5 \%$ salicylic acid alone; and iodine plus tea tree oil more effective than tea tree oil or iodine alone. We found more uncertain (low-quality) evidence to suggest that $10 \%$ potassium hydroxide is more effective than saline; homeopathic calcarea carbonica is more effective than placebo; $2.5 \%$ solution of potassium hydroxide is less effective than $5 \%$ solution of potassium hydroxide; and $10 \%$ povidone iodine solution and $50 \%$ salicylic acid plaster are more effective than salicylic acid plaster alone.

Except for the severe application site reactions of imiquimod, none of these treatments led to serious adverse effects (low-quality evidence). Pain during treatment application, redness, and itching were among the most reported adverse effects.

We found no differences between the treatments assessed in the other comparisons.

We found no randomised trials for several commonly used treatments, such as expressing lesions with an orange stick or topical hydrogen peroxide. Since most lesions resolve within months, unless better evidence for the superiority of active treatments emerges, molluscum contagiosum can be left to heal naturally.

\section{Quality of the evidence}

For topical imiquimod, the quality of the evidence for clinical cure, short-term improvement, and adverse effects was moderate to high. For all other comparisons, the quality of the evidence for short-term clinical cure and adverse effects was low. Common limitations of the included studies were that the numbers of participants were small, the investigators were not blinded, and participants who did not complete the study (numerous in some studies) were not included in the analyses. 
SUMMARY OF FINDINGS

\section{Summary of findings for the main comparison. Imiquimod versus vehicle for cutaneous molluscum contagiosum}

Imiquimod versus vehicle for cutaneous molluscum contagiosum

Patient or population: molluscum contagiosum

Setting: dermatology outpatient departments

Intervention: topical imiquimod

Comparison: topical vehicle

\begin{tabular}{|c|c|c|c|c|c|c|}
\hline \multirow[t]{2}{*}{ Outcomes } & \multicolumn{2}{|c|}{ Anticipated absolute effects ${ }^{\star}(95 \% \mathrm{Cl})$} & \multirow{2}{*}{$\begin{array}{l}\text { Relative effect } \\
(95 \% \mathrm{Cl})\end{array}$} & \multirow{2}{*}{$\begin{array}{l}\text { № of partici- } \\
\text { pants } \\
\text { (studies) }\end{array}$} & \multirow{2}{*}{$\begin{array}{l}\text { Quality of the } \\
\text { evidence } \\
\text { (GRADE) }\end{array}$} & \multirow[t]{2}{*}{ Comments } \\
\hline & $\begin{array}{l}\text { Risk with topi } \\
\text { cal vehicle }\end{array}$ & $\begin{array}{l}\text { Risk with topical } \\
\text { imiquimod }\end{array}$ & & & & \\
\hline \multirow{2}{*}{$\begin{array}{l}\text { Short-term clinical cure (up to } 3 \text { months after start } \\
\text { of treatment) (completely cleared short term) } \\
\text { Assessed with: observer assessed } \\
\text { Follow-up: mean } 12 \text { weeks }\end{array}$} & \multicolumn{2}{|c|}{ Study population } & \multirow{2}{*}{$\begin{array}{l}\text { RR } 1.33 \\
\text { (0.92 to } 1.93 \text { ) }\end{array}$} & \multirow{2}{*}{$\begin{array}{l}850 \\
\text { (4 RCTs) }\end{array}$} & \multirow{2}{*}{$\begin{array}{l}\oplus \oplus \oplus \circ \\
\text { MODERATE } 1\end{array}$} & \multirow[t]{2}{*}{ Analysis 1.1} \\
\hline & 118 per 1000 & $\begin{array}{l}156 \text { per } 1000 \\
(108 \text { to } 227)\end{array}$ & & & & \\
\hline \multirow{2}{*}{$\begin{array}{l}\text { Medium-term clinical cure (after } 3 \text { months and up } \\
\text { to } 6 \text { months after start of treatment) (completely } \\
\text { cleared medium term) } \\
\text { Assessed with: observer assessed } \\
\text { Follow-up: mean } 16 \text { weeks }\end{array}$} & \multicolumn{2}{|c|}{ Study population } & \multirow{2}{*}{$\begin{array}{l}\text { RR } 0.88 \\
\text { (0.67 to } 1.14 \text { ) }\end{array}$} & \multirow{2}{*}{$\begin{array}{l}702 \\
(2 \mathrm{RCTs})\end{array}$} & \multirow{2}{*}{$\begin{array}{l}\oplus \oplus \oplus \circ \\
\text { MODERATE } 2\end{array}$} & \multirow[t]{2}{*}{ Analysis 1.2} \\
\hline & 272 per 1000 & $\begin{array}{l}239 \text { per } 1000 \\
(182 \text { to } 310)\end{array}$ & & & & \\
\hline \multirow{2}{*}{$\begin{array}{l}\text { Long-term clinical cure (beyond } 6 \text { months after } \\
\text { start of treatment) (completely cleared long term) } \\
\text { Assessed with: observer assessed } \\
\text { Follow-up: mean } 28 \text { weeks }\end{array}$} & \multicolumn{2}{|c|}{ Study population } & \multirow{2}{*}{$\begin{array}{l}\text { RR } 0.97 \\
\text { (0.79 to } 1.17)\end{array}$} & \multirow{2}{*}{$\begin{array}{l}702 \\
\text { (2 RCTs) }\end{array}$} & \multirow{2}{*}{$\begin{array}{l}\oplus \oplus \oplus O \\
\text { MODERATE } 2\end{array}$} & \multirow[t]{2}{*}{ Analysis 1.3} \\
\hline & 401 per 1000 & $\begin{array}{l}389 \text { per } 1000 \\
\text { (317 to } 469)\end{array}$ & & & & \\
\hline \multirow{2}{*}{$\begin{array}{l}\text { Short-term clinical improvement (up to } 3 \text { months } \\
\text { after start of treatment) } \\
\text { Assessed with: observer assessed } \\
\text { Follow-up: mean } 12 \text { weeks }\end{array}$} & \multicolumn{2}{|c|}{ Study population } & \multirow{2}{*}{$\begin{array}{l}\text { RR } 1.14 \\
(0.89 \text { to } 1.47)\end{array}$} & \multirow{2}{*}{$\begin{array}{l}850 \\
\text { (4 RCTs) }\end{array}$} & \multirow{2}{*}{$\begin{array}{l}\oplus \oplus \oplus \oplus \\
\mathrm{HIGH}^{3}\end{array}$} & \multirow[t]{2}{*}{ Analysis 1.4} \\
\hline & 487 per 1000 & $\begin{array}{l}555 \text { per } 1000 \\
(433 \text { to } 716)\end{array}$ & & & & \\
\hline \multirow[t]{2}{*}{ Any adverse effect } & \multicolumn{2}{|c|}{ Study population } & \multirow{2}{*}{$\begin{array}{l}\text { RR } 0.97 \\
\text { (0.88 to } 1.07 \text { ) }\end{array}$} & \multirow{2}{*}{$\begin{array}{l}827 \\
\text { (3 RCTs) }\end{array}$} & \multirow{2}{*}{$\begin{array}{l}\oplus \oplus \oplus \oplus \\
\mathrm{HIGH}^{4}\end{array}$} & \multirow[t]{2}{*}{ Analysis 1.7} \\
\hline & 688 per 1000 & $\begin{array}{l}667 \text { per } 1000 \\
(606 \text { to } 736)\end{array}$ & & & & \\
\hline Application site reactions & Study populat & & $\begin{array}{l}\text { RR } 1.41 \\
\text { (1.13 to } 1.77)\end{array}$ & $\begin{array}{l}827 \\
\text { (3 RCTs) }\end{array}$ & $\begin{array}{l}\oplus \oplus \oplus \circ \\
\text { MODERATE } 5\end{array}$ & $\begin{array}{l}\text { Analysis } 1.8 . \\
\text { This outcome }\end{array}$ \\
\hline
\end{tabular}




\begin{tabular}{|c|c|c|c|c|c|c|c|}
\hline 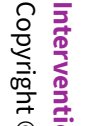 & & 261 per 1000 & $\begin{array}{l}368 \text { per } 1000 \\
\text { (295 to } 462 \text { ) }\end{array}$ & & & & $\begin{array}{l}\text { was not pre- } \\
\text { specified in our } \\
\text { protocol. }\end{array}$ \\
\hline 筧 & \multirow[t]{2}{*}{ Severe application site reactions } & \multicolumn{2}{|c|}{ Study population } & \multirow{2}{*}{$\begin{array}{l}\text { RR } 4.33 \\
\text { (1.16 to } 16.19 \text { ) }\end{array}$} & \multirow{2}{*}{$\begin{array}{l}827 \\
\text { (3 RCTs) }\end{array}$} & \multirow{2}{*}{$\begin{array}{l}\oplus \oplus \oplus \circ \\
\text { MODERATE } 5\end{array}$} & \multirow{2}{*}{$\begin{array}{l}\text { Analysis } 1.9 \text {. } \\
\text { This outcome } \\
\text { was not pre- } \\
\text { specified in our } \\
\text { protocol. }\end{array}$} \\
\hline 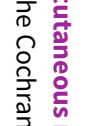 & & 7 per 1000 & $\begin{array}{l}29 \text { per } 1000 \\
(8 \text { to } 110)\end{array}$ & & & & \\
\hline
\end{tabular}

${ }^{*}$ The risk in the intervention group (and its 95\% confidence interval) is based on the assumed risk in the comparison group and the relative effect of the intervention (and its $95 \% \mathrm{Cl}$ ).

Cl: confidence interval; $\mathbf{R C T}$ : randomised controlled trial; RR: risk ratio

\section{GRADE Working Group grades of evidence}

High quality: We are very confident that the true effect lies close to that of the estimate of the effect.

Moderate quality: We are moderately confident in the effect estimate: The true effect is likely to be close to the estimate of the effect, but there is a possibility that it is substantially different.

Low quality: Our confidence in the effect estimate is limited: The true effect may be substantially different from the estimate of the effect.

Very low quality: We have very little confidence in the effect estimate: The true effect is likely to be substantially different from the estimate of effect.

${ }^{1}$ Downgraded by one level due to imprecision (<300 events). We decided not to downgrade for risk of bias as out of four studies, the largest three were judged to be at low risk of bias.

2Downgraded by one level due to imprecision ( $<300$ events). We decided not to downgrade for risk of bias as both studies were judged to be at low risk of bias.

3 We decided not to downgrade for risk of bias as out of four studies, the largest three were judged to be at low risk of bias. We also decided not to downgrade for inconsistency as removing one outlier eliminated inconsistency but hardly affected pooled estimate.

4 We decided not to downgrade for risk of bias as all three studies were judged to be at low risk of bias.

${ }^{5}$ Downgraded by one level due to imprecision (<300 events). We decided not to downgrade for risk of bias as all three studies were judged to be at low risk of bias. 


\section{B A C K G R O U N D}

\section{Description of the condition}

Molluscum contagiosum is a viral skin infection most frequently encountered in children (Chen 2013). The infection is caused by the molluscum contagiosum virus, which is classified within the family of poxviruses (Poxviridae) (Buller 1991). The virus is assumed to be the only remaining poxvirus that specifically affects human beings (Chen 2013).

Infection follows after contact with infected people or contaminated objects (Chen 2013). Molluscum contagiosum usually presents as single or multiple (usually no more than 20) painless, spherical, shiny, pearly white papules that classically have a central dimple. Their size may vary from tiny $1 \mathrm{~mm}$ papules to large nodules over $1 \mathrm{~cm}$ in diameter. The lesions may itch (Rogers 1998).

In addition to the common form of benign skin tumours (mostly found in children), there is also a sexually transmitted variant of molluscum contagiosum that occurs on genital, perineal, pubic, and surrounding skin (Czelusta 2000). Molluscum contagiosum lesions may also appear in or around the mouth (Whitaker 1991). Molluscum contagiosum has also been observed with other diseases in people with immune deficiency (Gottlieb 1994; Mansur 2004). People with HIV infection are particularly prone to molluscum contagiosum; prevalence in this population has been reported to range from 5\% to 18\% (Hira 1988; Husak 1997; Matis 1987). The focus of this review was the common form of molluscum contagiosum only.

\section{Epidemiology}

Molluscum contagiosum occurs worldwide. Previous reviews have reported that it as more frequent in geographic areas with warm climates, but this may be due to selective publication of local outbreaks (Olsen 2014). Infection is rare in children under the age of 1 year, typically occurring in the 2- to 5-year-old age group (Rogers 1998). The age of peak incidence is reported to be between the ages of 2 and 3 years in Fiji (Postlethwaite 1967), and between 1 and 4 years in the Congo (formerly Zaire) (Torfs 1959). In Papua New Guinea the annual incidence rate for children under 10 years of age was $6 \%$ (Sturt 1971). Population-based occurrence rates are scarce for high-income countries. In a large questionnaire study among parents of children attending kindergartens and elementary schools, the reported prevalence of molluscum contagiosum was $5.6 \%$ and $7.4 \%$, respectively (Niizeki 1984). Much higher prevalence rates have been reported during outbreaks in closed communities (Overfield 1966). In 1878 an outbreak in an English school was reported involving 9 children (Liveing 1878). A recent meta-analysis of five cross-sectional surveys among children (age range 0 to 16 years) resulted in a pooled prevalence rate of $2.8 \%$ ( $95 \%$ confidence interval 0.0 to 5.9) (Olsen 2014).

In the USA, the estimated number of physician visits for molluscum contagiosum from 1990 to 1999 was 280,000 per year (Molino 2004). One out of 6 Dutch children aged 15 years have visited their doctor for molluscum contagiosum at least once (Koning 1994). There is generally no difference in incidence between males and females (Koning 1994; Relyveld 1988; Sturt 1971); however, an unequal sex ratio was found in studies from Japan (Niizeki 1984), Alaska (Overfield 1966), and Fiji (Hawley 1970), where boys were affected more often. This is probably due to habits associated with the spread of the infection, such as swimming (Niizeki 1984; Postlethwaite 1967). Outbreaks may occur among children who bathe or swim together. A history of eczema was found in $62 \%$ of children with molluscum contagiosum in Australia (Braue 2005). In the adolescent and adult age groups sexual transmission becomes important.

\section{Natural history}

The estimated incubation period varies from 14 days to 6 months (Sterling 1998). Lesions enlarge slowly and may reach a diameter of 5 to $10 \mathrm{~mm}$ in 6 to 12 weeks (Sterling 1998). After trauma (e.g. scratching) or spontaneously after several months, inflammatory changes result in the production of white fluid, crusting, and eventual destruction of the lesions. The duration of both the individual lesion and of the entire episode is highly variable. Crops of molluscum may appear to come and go for several months, and although most cases are self limiting and resolve within six to nine months, some may persist for more than three or four years.

A Japanese study described spontaneous resolution on average 6.5 months after infection in 205 out of 217 children (94.5\%) affected by molluscum contagiosum (Takemura 1983). One month after the first consultation with the dermatologist, $23 \%$ of the children were cured. A recent community cohort study in the UK, Olsen 2015, followed 306 children with molluscum contagiosum aged 4 to 15 years. Only $19 \%$ of the children were reported to have received treatment. Mean time to resolution was 13.3 months; $30 \%$ had not resolved by 18 months, and 13\% had not resolved by 24 months.

Secondary bacterial infection can occur, and when severe can result in scarring. This must be distinguished from the milder inflammatory reactions that molluscum lesions show after a scratching or when they are starting to resolve spontaneously, which may prompt parents to take their child to the general practitioner thinking they have become infected (Highet 1992).

Particularly in atopic people (who are prone to asthma, hay fever, or eczema), there is a tendency for a patch of eczema (which is often particularly itchy) to develop around one or more of the lesions a month or more after their arrival (Beaulieu 2000; De Oreo 1956). Erythema annulare centrifugum (a widespread rash of red inflammatory rings) has also been reported (Vasily 1978). Chronic conjunctivitis and superficial punctate keratitis may likewise complicate lesions on or near the eyelids (Haellmigk 1966; Redmond 2004). The eczema and conjunctivitis diminish naturally when the molluscum lesion is removed.

Molluscum contagiosum behaves differently in HIV-infected individuals. As immunodeficiency progresses, molluscum contagiosum becomes more common and resistance to therapy increases. Frequently, multiple lesions in atypical areas such as the face and neck can be found (Husak 1997). Only limited data are available on the course of the disease in this group of people.

\section{Description of the intervention}

In people without an immune deficiency molluscum contagiosum is a self limiting disease (Chen 2013). Therapy is often not necessary for recovery, and awaiting spontaneous resolution is an important management strategy (Brown 2006; Chen 2013; Jones 2007; Olsen 2015; Takemura 1983). Most lesions resolve within months without scarring in otherwise healthy people (Ordoukhanian 1997). 
Treatment is intended to accelerate this process. Destruction of the lesions and the production of an inflammatory response are means by which resolution of the lesions could be hastened (Sterling 1998).

\section{Reasons to treat molluscum contagiosum include the following:}

- alleviating discomfort, including itching;

- cosmetic reasons;

- social stigma associated with many visible lesions;

- limiting its spread to other areas of the body and to other people;

- preventing scarring and secondary infection; and

- preventing trauma and bleeding of lesions.

There are a large number of treatment options for molluscum contagiosum (see Table 1 for an overview). These treatment options can be divided into three major categories:

- physical destruction of the lesions;

- topical agents (i.e. those applied directly to the lesions); and

- systemic treatment (i.e. those affecting the whole body).

In the past, many authors have recommended physical destruction as the preferred method for treatment of molluscum contagiosum (Smith 2002; Stulberg 2003; Williams 1991). Dermatology textbooks mention removal of the lesion with a sharp curette (curettage) or the application of liquid nitrogen (cryotherapy) as being simple and usually effective treatments (Lowy 1999; Sterling 1998). Gentle squeezing or pricking with a sterile needle are alternatively recommended destructive therapies (Berger 1996). Most of these therapies need to be repeated at three to four weekly intervals. Treatment may be painful and may result in scarring (Friedman 1987). Squeezing of lesions may even lead to the formation of large abscesses due to the disruption of virus into the deeper layer of the skin (dermis) (Brandrup 1989).

Topical preparations such as podophyllotoxin, liquefied phenol, tretinoin, cantharidin, or potassium hydroxide are also used (Hughes 2013; Metkar 2008; Saryazdi 2004; Silverberg 2000; Syed 1994; Weller 1999). In children, prior application of local anaesthetic cream may reduce the pain of treatment involving physical destruction or local inflammation (de Waard 1990; Rosdahl 1988), although severe side effects have been reported in a case of excessive application of lidocaine-prilocaine (Wieringa 2006). Other proposed topical treatments include immune response modifiers such as imiquimod and cidofovir.

Systemic treatment with cimetidine has been suggested as a possible treatment because of its systemic immunomodulatory effects; it increases lymphocyte proliferation and inhibits suppressor T-cell function (Orlow 1993; Sterling 1998).

Little data are available with regard to prevailing practice. In a survey among paediatric dermatologists in the USA in 2008, respondents seemed to favour cantharidin, followed by imiquimod, watchful waiting, curettage, and cryotherapy (Coloe 2009). This differs from, for example, general practice in the Netherlands, where waiting for natural resolution is the most popular option (Van der Linden 2005). A more recent survey among physicians from various specialties in the USA showed that treatment preferences differed widely between specialties (Hughes 2013).

\section{How the intervention might work}

The working mechanism differs according to the type of treatment (Chen 2013). Curettage aims to remove the lesions entirely. Other techniques like pricking with a needle, cryotherapy, or pulsed-dye laser aim at damaging the lesion, which may in itself induce an immune response. Topical preparations such as podophyllotoxin, tretinoin, cantharidin, or potassium hydroxide are supposed to evoke a local inflammatory response. Application of phenol or trichloroacetic acid also aims to destroy the lesions. Another topical preparation, imiquimod, supposedly induces an immune response. Cimetidine is a systemic immune modulator. Antiviral agents, especially cidofovir, have been used both systemically and locally (Chen 2013).

\section{Why it is important to do this review}

Molluscum contagiosum is a common reason for consultation in family practice and dermatology. Many treatment options are available, some of which are painful and some that may leave scars. A decision may be made in favour of active therapy to prevent further spread, relieve symptoms, prevent scarring, and for cosmetic and social reasons. Indeed, many parents are concerned about the stigma associated with the lesions. Children with molluscum may be excluded from attending nursery and from participating in physical activities such as swimming. However, the scientific basis for treatment is unclear. Consequently, many practitioners find themselves in a dilemma as to whether or not to promote active treatment and, if they do decide on an active treatment strategy, are unclear as to which is the best option. We carried out this systematic review to evaluate treatment options for molluscum contagiosum.

\section{OB JECTIVES}

To assess the effects of specific treatments and management strategies, including waiting for natural resolution, for cutaneous, non-genital molluscum contagiosum in people without immune deficiency.

\section{METHODS}

\section{Criteria for considering studies for this review}

\section{Types of studies}

Randomised controlled trials (RCTs) for the treatment of molluscum contagiosum. We excluded trials on sexually transmitted molluscum contagiosum and in people with an immune deficiency (including those with HIV infection).

\section{Types of participants}

People with a diagnosis of molluscum contagiosum, except for those with immune deficiency or sexually transmitted molluscum contagiosum.

In general, treatment was based on a clinical diagnosis only, as molluscum contagiosum is an easy diagnosis to make and confusion is rare among clinicians. We therefore considered additional diagnostic criteria, such as histological examination and laboratory investigations, as unnecessary. 


\section{Types of interventions}

All treatments aimed at eradicating molluscum contagiosum lesions, including:

- physical interventions;

- systemic treatments;

- topical agents; and

- awaiting natural resolution.

We excluded studies on other aspects of the treatment of molluscum contagiosum, for example on reducing pain in the studies that used analgesic EMLA (eutectic mixture of local anaesthetics) cream (de Waard 1990; Juhlin 1980).

\section{Types of outcome measures}

\section{Primary outcomes}

1. Short-term clinical cure (up to three months after start of treatment).

We defined clinical cure as complete disappearance (clearance) of molluscum contagiosum skin lesions, as assessed by a physician.

\section{Secondary outcomes}

1. Medium- and long-term clinical cure (after three months and up to six months after start of treatment, and beyond six months, respectively).

2. Short-, medium-, and long-term improvement (including cure, intervals as above).

3. Time to cure.

4. Recurrences after 3, 6, and 12 months.

5. Adverse effects of treatment such as pain, blistering, sensitisation, scarring, erosion, and pigmentary changes.

6. Spread to other people.

7. Disease-related quality of life.

Where included studies used the term 'complete clearance' or 'free of lesions' or 'cured or $>90 \%$ cleared', we classed these as our primary outcome 'short-term clinical cure (up to three months after start of treatment)' or our secondary outcome 'mediumand long-term cure (after three months and up to six months, and beyond six months, respectively)', and where they referred to 'partial clearance', we took this to mean our secondary outcome 'improvement'.

We did not initially specify secondary outcomes (2) and (7) in the protocol, but added them afterwards since we considered improvement at the end of the study important, as was diseaserelated quality of life. For secondary outcome (2), we would combine 'improvement' and 'cure' (even though cure alone was a seperate outcome) because 'improvement' would be hard to interpret without also including those who were cured. For example: suppose in group A, 30\% of participants were cured and another $20 \%$ improved. In group B, $40 \%$ of participants were cured and $10 \%$ improved. Comparing improvement rates between $A$ and $\mathrm{B}(20 \%$ versus $10 \%)$ is misleading, whereas combining cure and improvement ( $50 \%$ versus $50 \%$ ) is not.

\section{Search methods for identification of studies}

We aimed to identify all relevant RCTs regardless of language or publication status (published, unpublished, in press, or in progress).

\section{Electronic searches}

For this update, we revised all of our search strategies in line with current Cochrane Skin practices. Details of the previous search strategies are available in Van der Wouden 2009.

We searched the following databases up to 21 July 2016:

- the Cochrane Skin Group Specialised Register using the search strategy in Appendix 1;

- the Cochrane Central Register of Controlled Trials (CENTRAL) 2016, Issue 6, in the Cochrane Library using the strategy in Appendix 2;

- MEDLINE via Ovid (from 1946) using the strategy in Appendix 3;

- Embase via Ovid (from 1974) using the strategy in Appendix 4; and

- LILACS (Latin American and Caribbean Health Service Information database) (from 1982) using the strategy in Appendix 5.

\section{Trials registers}

For this update, we searched the following trials registers up to 4 August 2016, using 'molluscum' as the search term

- ISRCTN registry (www.isrctn.com);

- ClinicalTrials.gov (www.clinicaltrials.gov);

- Australian New Zealand Clinical Trials Registry (www.anzctr.org.au);

- World Health Organization International Clinical Trials Registry Platform (WHO ICTRP) (apps.who.int/trialsearch/);

- EU Clinical Trials Register (www.clinicaltrialsregister.eu); and

- Netherlands Trial Register (www.trialregister.nl).

Google

We searched Google combining the keyword 'molluscum' with author names of pertinent studies.

\section{Searching other resources}

\section{Reference lists}

We checked the bibliographies of included studies and review articles for further references to relevant studies.

\section{Correspondence}

We obtained further relevant published and unpublished trials via correspondence with selected pharmaceutical companies and authors of recent publications.

Three unpublished studies undertaken by $3 \mathrm{M}$ were brought to our attention by Dr Ken Katz, an American dermatologist. 


\section{Data collection and analysis}

\section{Selection of studies}

Two review authors (of SK, RvdS, EK, JCvdW) independently read all abstracts or titles of identified trials. If one of the review authors considered the article to be potentially relevant, we obtained a full-text copy of the article for further consideration. Two review authors (as before) independently examined all full-text articles to determine whether or not they met our inclusion criteria. Disagreements were resolved by discussion between the review authors, with referral to a third review author (JCvdW or SK) when necessary.

We excluded trials on sexually transmitted molluscum contagiosum and in people with immune deficiency (including those with HIV infection), in order to increase homogeneity of studies. If the full text of a study was not available, we considered published abstracts for the review.

If an RCT included a variety of skin diseases, of which one was molluscum contagiosum, the number of molluscum participants needed to be at least five in the active treatment and placebo groups. We added this criterion after approval of the protocol when a we found a study that included 10 molluscum participants with a 9:1 distribution over the two treatment groups (Caballero 1996).

If the setting of the study was not explicitly mentioned in the text, we assumed it to be carried out at the affiliation of the first author.

\section{Data extraction and management}

Two review authors (of SK, RvdS, EK, JCvdW) independently carried out data extraction using specially developed and piloted data extraction forms. Discrepancies were resolved by a third review author (JCvdW or SK). We obtained missing data from study authors where possible. One review author (JCvdW) entered the data.

As planned in our protocol, the review authors were not blinded to the names of authors, journals, or institutions.

\section{Assessment of risk of bias in included studies}

Two review authors (of SK, RvdS, EK, JCvdW) independently assessed the included studies for risk of bias using Cochrane's 'Risk of bias' tool (Higgins 2011). The review authors were not blinded to the names of authors, journals, or institutions. A third review author (JCvdW or SK) acted as arbitrator when necessary. Our assessment included an evaluation of the following components.

1. Method of generation of the randomisation sequence: it was considered adequate when a computer program or a random number table was used, or a statistician was involved.

2. Method of allocation concealment: it was considered adequate if the assignment could not be foreseen.

3. Blinding of participants, clinicians: it was considered adequate when the study was called 'double-blind' and precautions were taken to mask the nature of the interventions.

4. Blinding of outcome assessors: it was considered adequate when the study was called 'double-blind' and it was unlikely that difference in treatment resulted in unmasking (e.g. in the case of staining due to one of the treatments).

5. Incomplete outcome data addressed (short, medium, and long term): it was scored 'unclear' if not reported and 'high risk' if >
$20 \%$ of participants lost to follow-up (short term) or $>30 \%$ lost to follow-up (long term) (Back Review Group 2008).

6. Free of selective reporting: it was considered adequate if the reported outcomes were similar to those mentioned in the study protocol.

7. Free of other bias, such as baseline imbalance, compliance, and unit of analysis errors in the case of multiple lesions.

Items (5), (6), and (7) differed from the original protocol or were absent, and were initially adapted for the 2009 update. Items (3) and (4) were combined in one item in the previous versions of this review.

\section{Assessment of quality of the evidence}

We used GRADE to assess the overall quality of the evidence for each outcome of each comparison. Starting from 'high quality' (because we only included RCTs), we downgraded the quality for serious study limitations (high risk of bias), indirectness of evidence, serious inconsistency, imprecision of effect estimates (fewer than 300 events), or potential publication bias.

\section{Measures of treatment effect}

For dichotomous outcomes, we expressed the results as risk ratios (RR) with 95\% confidence intervals ( $\mathrm{Cl}$ ) and as a number needed to treat (NNT) only for comparisons with two or more studies and only in case of statistically significant outcomes (the latter in order to avoid confusing confidence interval boundaries). For continuous outcomes, we expressed the results as weighted mean differences (WMD) with $95 \% \mathrm{Cl}$.

Following the Cochrane Skin Group recommendations, we decided post hoc to re-analyse results from individual studies with borderline significance and with low numbers of events (fewer than 10 in total) or a total sample size of less than 30 , using Fisher's exact test. The resulting $\mathrm{P}$ value was leading in interpreting the results.

\section{Unit of analysis issues}

We could expect unit of analysis issues regarding studies potentially using within-participant comparisons (e.g. split-body studies) and cross-over trials. An additional problem of split-body studies is when a locally applied treatment could induce a systemic response. Our protocol stated that data from these trials were to be analysed using techniques appropriate for paired designs, with the help of a statistician (Van der Wouden 2004).

\section{Dealing with missing data}

We attempted to obtain missing data from the trial authors. If this was not possible or not feasible, we used the data as reported.

\section{Assessment of heterogeneity}

We planned to explore heterogeneity between the studies using the $\mathrm{I}^{2}$ statistic. If substantial heterogeneity $\left(\mathrm{I}^{2}\right.$ statistic $\left.>50 \%\right)$ existed between studies for the primary outcome, we planned to explore the reasons for the heterogeneity, for example by using sensitivity analyses to examine the effects of excluding studies with high risk of bias.

\section{Assessment of reporting biases}

We planned to assess reporting bias by comparing the published trial publications with the study protocol. 


\section{Data synthesis}

For studies with a similar type of intervention, we conducted metaanalyses to calculate a weighted treatment effect across trials using a random-effects model (DerSimonian and Laird model) (Higgins 2011).

When the same comparison between two interventions was made in more than one study, and studies appeared to have been executed in similar groups and settings, we used statistical tests for homogeneity between studies. In those studies where the available data were sufficiently homogenous and where a pooled estimate of the treatment effect made sense, we conducted a meta-analysis.

Where a quantitative synthesis was not possible we provided a narrative synthesis of included trials, presenting the main characteristics of trials and their results.

For studies with a similar type of intervention, we conducted metaanalyses to calculate a weighted treatment effect across trials using a random-effects model (DerSimonian and Laird model).

\section{Sensitivity analysis}

We planned to use sensitivity analyses to examine the effects of excluding studies with high risk of bias.

\section{Summary of findings}

We developed 'Summary of findings' tables subsequent to our protocol. For this update we produced a 'Summary of findings' table for what we believe is the most important comparison of this update: imiquimod versus vehicle.

\section{RESULTS}

\section{Description of studies}

\section{Results of the search}

Our update of the database searches to July 2016 identified 64 records. We identified an additional 15 records from other sources including trial registers, resulting in a total of 79 records to be screened. We excluded 50 records based on titles and abstracts. Of the remaining 29 records, 5 were not available in full text and for 3 others were available in full text but insufficient information was provided to decide on inclusion or exclusion (see Characteristics of studies awaiting classification). We identified one ongoing study (see Characteristics of ongoing studies). We excluded a further nine studies (see Characteristics of excluded studies). We included 11 new studies (see Characteristics of included studies).

We combined these studies with those previously identified for this review, resulting in a total of 22 included studies. A flow diagram summarising the study selection process is shown in Figure 1. 
Figure 1. Flow diagram of inclusion for this update.

Previous version of review: 11 included studies
64 records identified through database searching after deduplication
15 additional records identified through other sources (Google, references, FDA, trial registers)

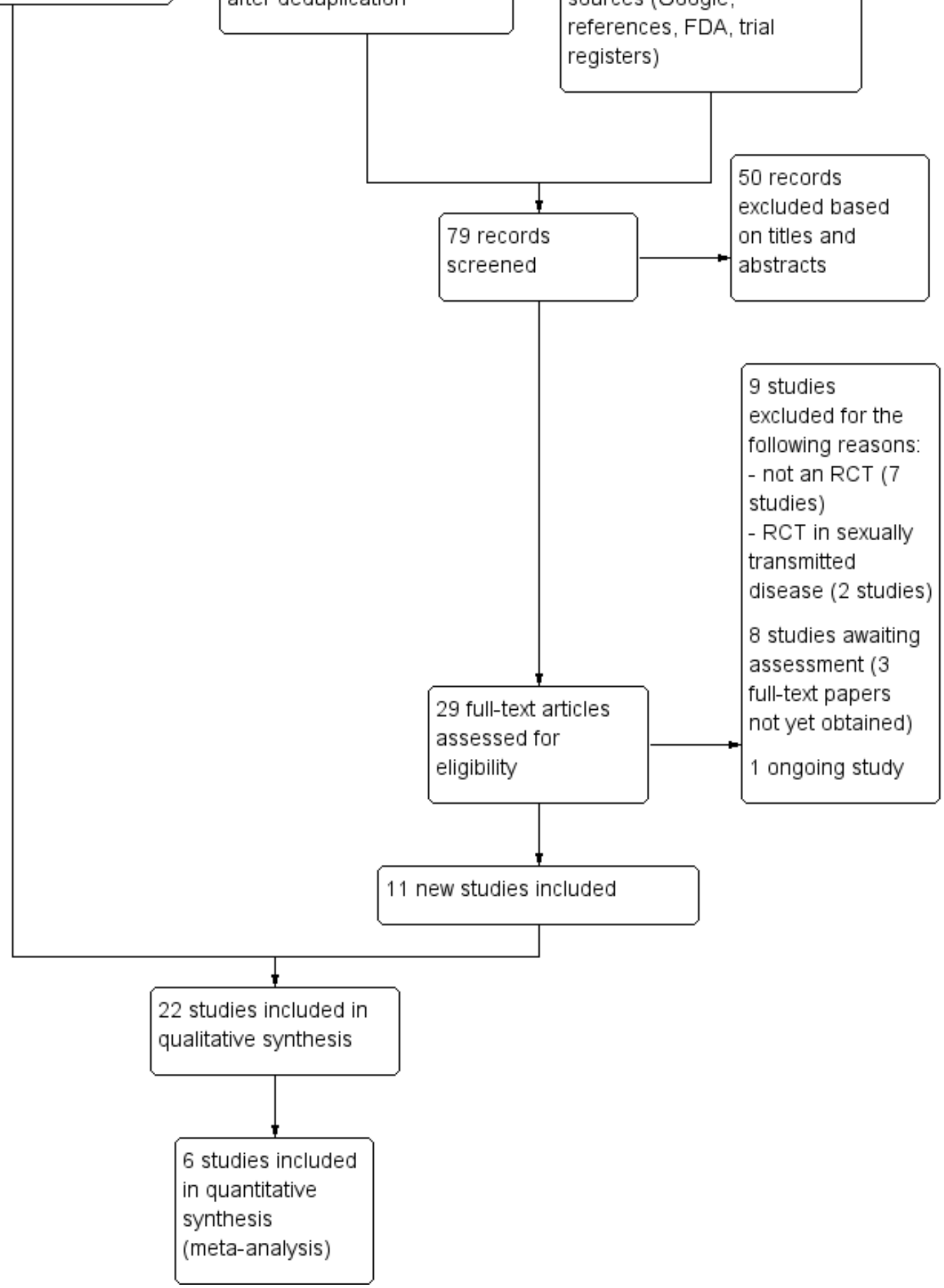




\section{Included studies}

We identified 11 new studies for this update, resulting in a total of 22 included studies. The newly included studies are: Al-Mutairi 2010; Chathra 2015; Coloe Dosal 2014; Eichenfield 2005; Handjani 2014; Machado 2010; Markum 2012; Paller 2005a; Paller 2005b; Seo 2010; Uçmak 2013.

\section{Setting}

Eight trials were performed in North America, five in the UK, eight in Asia, and one in South America (see Characteristics of included studies).

Most included studies were set in hospital outpatient or emergency departments. Only people without immune deficiency (non-HIV participants) and non-genital molluscum contagiosum participants were included in the studies. Participants therefore consisted primarily of children and young adults (adolescents).

\section{Participants}

The 22 included studies involved a total of 1650 randomised molluscum participants, more than three times as many as in the previous version of this review. The number of participants in each study ranged from 20, in Manchanda 1997b and Short 2006, to 379, in Paller 2005b.

\section{Design}

Most of the studies had two trial arms. Four studies had three arms (Leslie 2005; Machado 2010; Markum 2012; Ohkuma 1990), and one study had four arms (Hanna 2006). The number of participants per trial arm ranged from 5, in Ohkuma 1990, to 253, in Paller 2005b. Manchanda 1997b reported on two studies, both making the same comparison but one in a cross-over design and one in a parallel design. We chose not to include the cross-over study because fewer than five molluscum participants were assigned to one of the treatment arms. See below for more details on the study designs. Follow-up duration ranged from 3 to 28 weeks after randomisation. Only five studies had longer than 3 months' follow-up (Al-Mutairi 2010; Antony 2001; Eichenfield 2005; Leslie 2005; Paller 2005b).

\section{Publications}

We obtained 17 studies as full-text articles; in five cases these were unpublished manuscripts (Bazza 2007; Eichenfield 2005; Paller 2005a; Paller 2005b; Short 2006). The three unpublished studies by $3 \mathrm{M}$, all addressing the same comparison, imiquimod versus placebo, were brought to our attention by Dr Ken Katz, an American dermatologist. These unpublished studies were mentioned in an FDA summary, Papadopoulos 2007, and subsequently in several journal articles (Katz 2013; Katz 2014; Katz 2015). Upon our request, the director of Meda Pharma BV (Amstelveen, the Netherlands) provided us with the full reports of these three trials.

Two studies were available only as published abstracts (Antony 2001; Saryazdi 2004). We requested and obtained additional information from the authors of several of the included studies (Manchanda 1997b; Ohkuma 1990; Short 2006).

\section{Funding}

Five studies reported obtaining commercial funding (Burke 2004; Eichenfield 2005; Markum 2012; Paller 2005a; Paller 2005b); three other studies obtained medication for free from pharmaceutical companies (Hanna 2006; Leslie 2005; Machado 2010); one study reported charity funding (Coloe Dosal 2014); and one study reported receiving no financial support (Chathra 2015). The other 12 studies did not report on funding.

\section{Interventions}

Twenty studies evaluated topical therapies for molluscum contagiosum. Two studies included curettage as a treatment arm (Hanna 2006; Machado 2010). Two studies investigated systemic treatments (Antony 2001; Manchanda 1997b). Below we have provided some information regarding interventions, measurements, and loss to follow-up for each study. For further details, see Characteristics of included studies.

\section{Topical therapy}

Three studies by $3 \mathrm{M}$ Pharmaceuticals all compared $5 \%$ imiquimod with its vehicle in children (Eichenfield 2005; Paller 2005a; Paller 2005b). Paller 2005a used a 1:1 randomisation scheme; the other two studies used a 2:1 scheme. In total, 532 children were randomised to the imiquimod arms and 295 children were randomised to the vehicle arms. Treatment frequency and duration varied from daily for 8 weeks, in Paller 2005a, to 3 times weekly for a maximum of 16 weeks (Eichenfield 2005; Paller 2005b). The total number of evaluable participants was 623 , that is $76 \%$ of those randomised. Outcomes were lesion clearance, lesion counts, time to complete clearance, and side effects after 4, 8, 12, 16, 18, and 28 weeks after the start of treatment (Eichenfield 2005; Paller 2005b); and lesion clearance, lesion counts, time to complete clearance, and side effects 12 weeks after the start of treatment (Paller 2005a).

Al-Mutairi 2010 assessed the effect of $5 \%$ imiquimod 5 times a week $(n=37)$ with that of cryospray once a week $(n=37)$ for a maximum of 16 weeks in children 2 to 12 years of age. No loss to follow-up was reported. Outcomes were cure at 3,6,12, and 16 weeks; cosmetic outcome; and adverse effects.

Bazza 2007 assessed the effect of 5\% potassium hydroxide compared to $0.9 \%$ saline twice daily. The design was a withinparticipant comparison, with treatment randomised to the right or left side of the body. Treatment was continued for a maximum period of three weeks. The study included 30 participants, of whom 20 participants ( 2 to 12 years of age) completed the study. Outcomes were complete clearance of lesions and side effects after 12 weeks.

Burke 2004 assessed the effect of 10\% Australian lemon myrtle tree oil once daily $(n=16)$. The control group $(n=15)$ received the vehicle, olive oil. Treatment was continued for 21 days. The mean age of the participants was 4.6 years. Four children were lost to follow-up. Outcome was complete clearance or greater than $90 \%$ reduction in number of lesions after 3 weeks.

Chathra 2015 compared 5\% imiquimod ( $n=20$ ) to $10 \%$ potassium hydroxide $(n=20) 3$ times a week for up to 12 weeks. Age range was 1 to 18 years. There was no loss to follow-up. Outcome was complete clearance after 4,8 , and 12 weeks.

Coloe Dosal 2014 compared $0.7 \%$ cantharidin $(n=16)$ with its vehicle $(n=16)$ for a maximum of 8 weeks, applied at 5 subsequent visits. Age of the participants was 5 to 10 years. No follow-up data were available for three children in the $0.7 \%$ cantharidin group. 
Outcomes were complete clearance, lesion counts, and adverse effects at approximately 8 weeks after the start of treatment.

Handjani 2014 compared $10 \%$ potassium hydroxide 2 times daily (n $=15)$ with cryotherapy once weekly $(n=15)$ for up to 4 weeks. Age of the participants was 1 to 24 years, mean 6.4 years. There was no loss to follow-up. Outcomes were lesion response and side effects 4 weeks after the start of treatment.

Hanna 2006 compared four treatments: $5 \%$ imiquimod $(n=29)$, $0.7 \%$ cantharidin $(n=30), 16.7 \%$ salicylic acid/16.7\% lactic acid $(n=29)$, and curettage (physical destruction) $(n=31)$. Treatment frequency varied and neither treatment duration nor the time point for measuring whether participants were cured was reported. Age of the participants was 1 to 16 years. Loss to follow-up was unclear. Outcome was the number of visits required. The intervals between study visits were not reported, therefore outcome data were not suitable for analysis.

Leslie 2005 compared the effect of $10 \%$ phenol/70\% alcohol $(n=$ 41 ) to $12 \%$ salicylic acid $(n=37)$ and to $70 \%$ alcohol $(n=36)$. Age of the participants was 1 to 15 years. Treatment frequency varied. Participants returned for additional treatment for up to six months. Thirty-one participants (27\%) were lost to follow-up. Outcome was complete clearance of lesions after six months.

Machado 2010 reported on a study with three arms: $10 \%$ potassium hydroxide two times daily $(n=17) ; 14 \%$ salicylic acid plus $14 \%$ lactic acid in collodion once daily $(n=16)$; and curettage $(n=17)$. The first two groups were treated for 90 days; curettage was performed only once. Age of the participants was 3 to 15 years. No losses to followup were reported. Outcomes were cure and adverse effects 90 days after the start of treatment.

Markum 2012 also reported on a study with three arms: iodine ( $\mathrm{n}$ = 16); tea tree oil (Melaleuca alternifolia) $(n=18)$; and tea tree oil combined with iodine $(n=19)$ twice daily for a maximum of 30 days. The mean age of participants was 6.3 years. A total of five children were lost to follow-up. Outcomes were cure or reduction in the number of lesions of greater than $90 \%$ and adverse effects 30 days after the start of treatment.

Ohkuma 1990 had three intervention arms: 10\% povidone iodine solution combined with $50 \%$ salicylic acid plaster $(n=20)$, povidone iodine alone $(n=5)$, and salicylic plaster alone $(n=10)$, all once daily. Age of the participants was 2 to 9 years. Outcome was time to cure.

Ormerod 1999 assessed the effect of 5\% sodium nitrite co-applied daily with $5 \%$ salicylic acid, under occlusion $(n=16)$. The control group received an identical cream with $5 \%$ salicylic acid but without sodium nitrite $(n=14)$. Treatment was for three months or until participants were cured or dropped out if sooner. The median age of the participants was 6 years. Outcomes were time to complete resolution and adverse events.

Saryazdi 2004 compared the effect of $10 \%$ benzoyl peroxide cream with $0.05 \%$ tretinoin cream twice daily for 4 weeks. Participants were children; their age was not specified. The total number of participants was 30; we assumed these were equally divided between the 2 treatments. Outcomes were lesion count, lesion free, and side effects six weeks after the start of treatment.

Seo 2010 compared the effect of once daily $5 \%$ imiquimod cream (n $=15$ ) with that of once daily $10 \%$ potassium hydroxide solution ( $\mathrm{n}$
= 15) for a maximum of 12 weeks. Age of the participants was 1 to 36 years. Three participants were lost to follow-up. Outcomes were cure and adverse effects after 2, 4, 8, and 12 weeks.

Short 2006 assessed the application of a 10\% potassium hydroxide solution $(n=10)$ twice daily. The control group received saline ( $n$ $=10$ ). Assessment of the therapeutic response took place up to 90 days after the start of treatment or 1 month after clearance, or both. Age of the participants was 2 to 9 years. One child was lost to followup. Outcomes were time to resolution and adverse events three months after the start of treatment.

Theos 2004 assessed the effect of $5 \%$ imiquimod $(n=12)$ versus vehicle $(n=11) 3$ times a week for up to 12 weeks. Participants were assessed every 2 weeks after treatment initiation, for up to 12 weeks. Age of the participants was 1 to 9 years. Two children were lost to follow-up. Outcomes were complete and partial clearance and adverse events after 4,8 , and 12 weeks.

Uçmak 2013 compared 2.5\% potassium hydroxide $(n=14)$ with $5 \%$ potassium hydroxide $(n=15)$ twice daily for 60 days. Age of the participants was 1 to 18 years. Three participants were lost to follow-up. Outcomes were cure and adverse effects after 15, 30, 45, and 60 days.

\section{Systemic therapy}

Antony 2001 assessed the effect of $35 \mathrm{mg} / \mathrm{kg} /$ day of cimetidine given once daily as an oral suspension for three months. Thirtyeight participants, aged 1 to 16 years, were enrolled in the trial, but assignment details were provided only for the 19 participants who completed the study. Eight of these participants were randomised to the treatment arm of the trial. The 11 participants in the control arm received a matched oral suspension. The follow-up period was four months from the start of treatment. Outcomes were complete clearance after four months of treatment and reduction of lesions.

Manchanda 1997b evaluated different potencies of the homoeopathic drug calcarea carbonica given daily for 15 days $(n=14)$. Six participants were randomised to receive plain sugar globules as a placebo. Age of the participants was 0 to 30 years. Follow-up duration was not reported. Outcome was improvement (not clear after what period).

\section{Excluded studies}

The most common reasons why studies were excluded was that they were case series rather than RCTs, or because the participant groups were outside the focus of the review. See the 'Characteristics of excluded studies' tables.

\section{Studies awaiting classification}

We have assigned eight studies to awaiting classification. Two studies classified as ongoing in the previous version of this review have likely been completed (NCT01348386; NCT02665260), however we are unaware of papers describing the results of these studies. For three other studies identified in the current search but rather old, we were unsuccessful in obtaining full-text papers, and abstracts are missing as well (Elzawahry 1964; Tanissa 1951; Unknown Chinese author 1991). For the remaining three studies, full-text papers were available, but insufficient information was provided to decide on inclusion or exclusion (Köse 2013; Muzaffar 2014; Rajouria 2011). All three studies compared topical treatments: a Turkish study compared a $10 \%$ potassium hydroxide 
solution with a combination of salicylic and lactic acid; a study from Pakistan compared two different potassium hydroxide solutions ( $5 \%$ versus $10 \%$ ); and a study from Nepal compared $5 \%$ potassium hydroxide solution with $0.05 \%$ tretinoin cream. We have contacted the authors for additional information, but have been unsuccessful thus far.

\section{Ongoing studies}

We found one ongoing study comparing topical treatments: $10 \%$ sandalwood cream versus placebo cream. It is being conducted in the USA (NCT02024581).

\section{Risk of bias in included studies}

Figure 2 and Figure 3 show the results of the 'Risk of bias' assessment. Reasons for the choices that were made for each individual study can be found in the Characteristics of included studies. Overall, most study reports provided insufficient information to judge risk of bias, especially for allocation concealment and selective reporting. We considered only five studies to be at low risk of bias: Coloe Dosal 2014; Eichenfield 2005; Markum 2012; Paller 2005a; Paller 2005b; all of these studies were identified during the 2016 update. 
Figure 2. Risk of bias table: review authors' judgements about each methodological quality item for each included study.

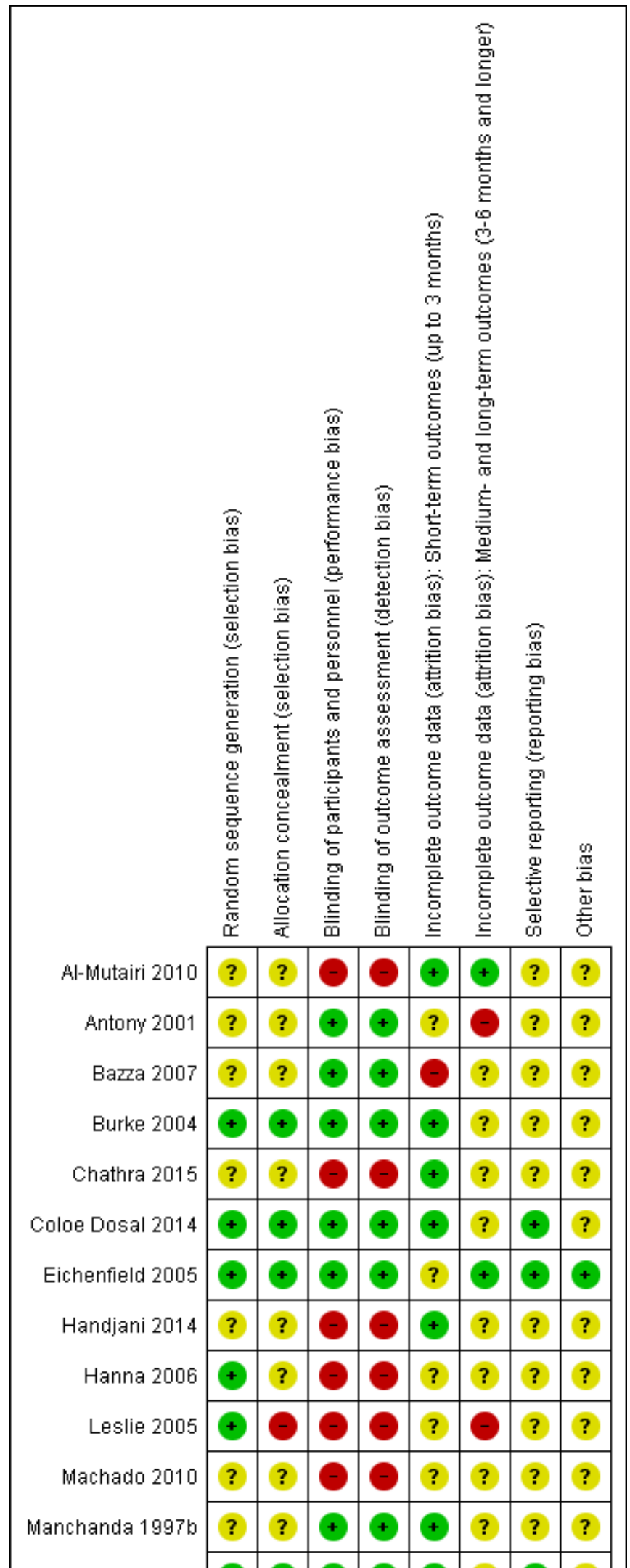


Figure 2. (Continued)

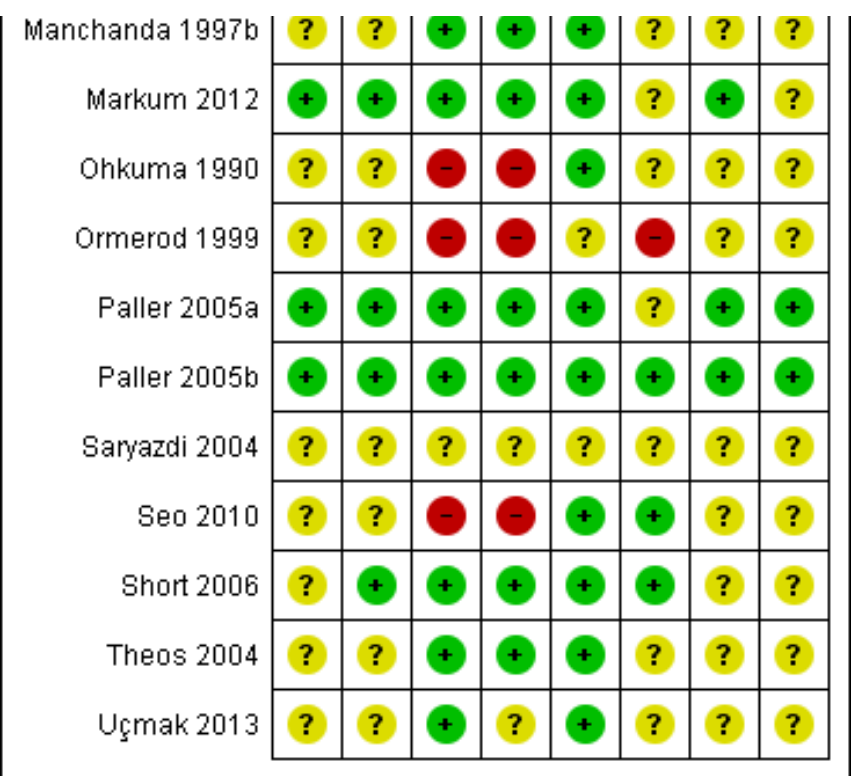

Figure 3. Risk of bias graph: review authors' judgements about each risk of bias item presented as percentages across all included studies.

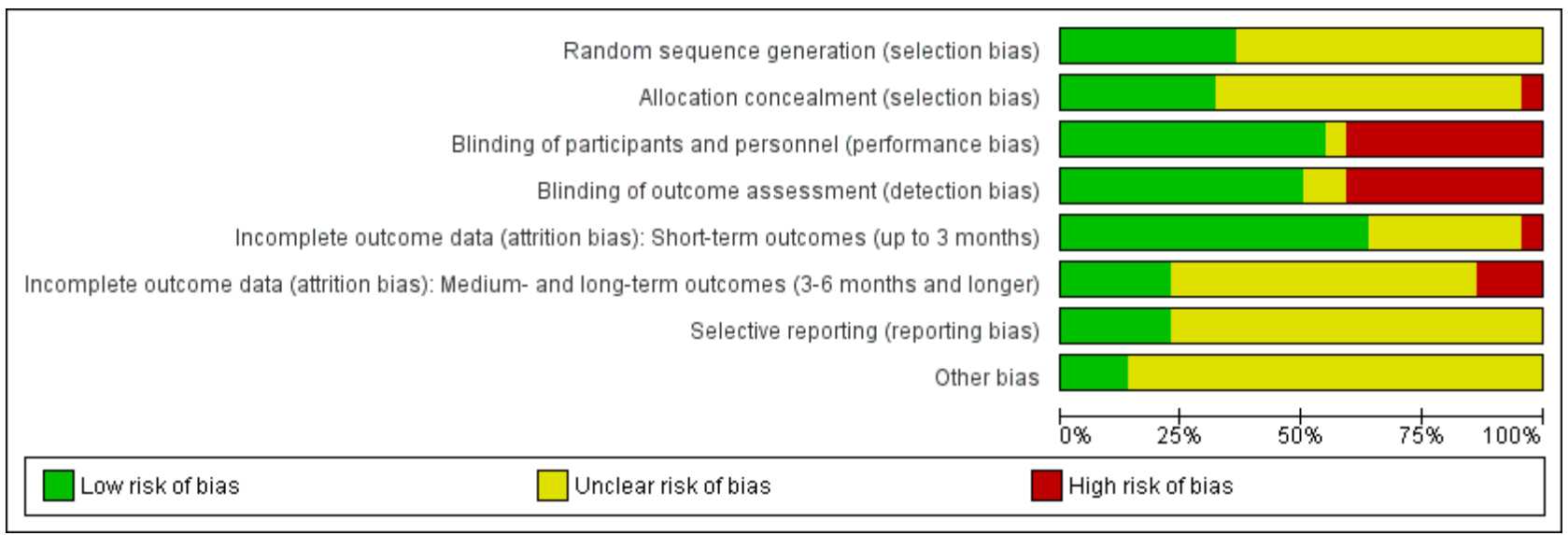

\section{Allocation}

Twenty studies were described in the text as randomised trials. We obtained additional information from the authors of the other two papers, who confirmed in writing that the participants were randomised into the different treatment groups (Manchanda 1997b; Ohkuma 1990). Eight papers described the way the randomisation sequence was generated (Burke 2004; Coloe Dosal 2014; Eichenfield 2005; Hanna 2006; Leslie 2005; Markum 2012; Paller 2005a; Paller 2005b), which we judged as at low risk of bias (Figure 2). In a personal communication, Manchanda informed us that in his study this was "generated manually" (Manchanda 1997b).

Only seven studies described whether the investigators took any precautions to conceal the allocation schedule from those involved in entering participants into the study (Burke 2004; Coloe Dosal
2014; Eichenfield 2005; Markum 2012; Paller 2005a; Paller 2005b; Short 2006).

\section{Blinding}

Eleven of the studies were described as double-blind. However, only four of these studies provided information about the similarity in appearance and smell of treatments (Burke 2004; Coloe Dosal 2014; Manchanda 1997b; Markum 2012). In four socalled vehicle-controlled studies, visual similarity was not explicitly stated but can be assumed (Eichenfield 2005; Paller 2005a; Paller 2005b; Theos 2004). None of the papers provided information on whether blinding was maintained throughout follow-up. Ormerod reported brown staining on the skin in six participants with active treatment, but none of the controls, which may have unblinded outcome assessment (Ormerod 1999). In some studies blinding was impossible due to the comparison that was made (e.g. topical cream versus cryospray (Al-Mutairi 2010)). Blinding was unclear in 
Saryazdi 2004. In Uçmak 2013, participants seemed to be blinded but for the outcome assessors this was unclear. We considered the following studies not to be (fully) blinded: Al-Mutairi 2010; Chathra 2015; Handjani 2014; Hanna 2006; Leslie 2005; Ohkuma 1990; Ormerod 1999; Seo 2010. Further details are provided in Characteristics of included studies.

\section{Incomplete outcome data}

In Figure 2, we have reported this item separately for short-term outcomes and longer-term outcomes. For short-term outcomes, only one study reported a loss to follow-up of more than 20\% (Bazza 2007). Six studies did not report any loss to follow-up (Al-Mutairi 2010; Chathra 2015; Handjani 2014; Machado 2010; Ohkuma 1990; Saryazdi 2004). For longer-term outcomes, three studies reported a loss to follow-up of over $30 \%$.

\section{Selective reporting}

We could not evaluate selective reporting for most of the included studies because neither a study protocol was available, nor a trial register providing information on outcomes. We judged five studies to be free of reporting bias (Coloe Dosal 2014; Eichenfield 2005; Markum 2012; Paller 2005a; Paller 2005b). Several studies reported that efficacy was assessed at several time points but results were provided only at the last time point. We did not qualify this as high risk of bias.

\section{Other potential sources of bias}

For most studies, it was unclear whether other sources of bias played a role, because no information was provided on baseline characteristics or adherence to the treatment protocol (Figure 2). One study reported that the treatment adherence differed between study arms (Machado 2010), and other studies reported considerable baseline imbalances for lesion count (Theos 2004), sex (Seo 2010), and skin dryness (Coloe Dosal 2014), but the differences were not statistically significant. We judged three studies to be at low risk of bias for this item because there was no relevant baseline imbalance and information was provided on adherence to the treatment protocol (Eichenfield 2005; Paller 2005a; Paller 2005b). For funding sources of studies, see above under Funding. We did not take the source of funding into account for the 'Risk of bias' assessment.

\section{Effects of interventions}

See: Summary of findings for the main comparison Imiquimod versus vehicle for cutaneous molluscum contagiosum

Our prespecified outcomes were as follows.

\section{Primary outcomes}

1. Short-term clinical cure (up to three months after the start of treatment).

We defined clinical cure as complete disappearance (clearance) of molluscum contagiosum skin lesions, as assessed by a physician.

\section{Secondary outcomes}

1. Medium- and long-term clinical cure (after three months and up to six months after start of treatment, and beyond six months, respectively).
2. Short-, medium-, and long-term improvement (including cure, intervals as above).

3. Time to cure.

4. Recurrences after 3, 6, and 12 months.

5. Adverse effects of treatment such as pain, blistering, sensitisation, scarring, erosion, and pigmentary changes.

6. Spread to other people.

7. Disease-related quality of life.

We describe here the prespecified outcomes found for all comparisons. Comparisons are sorted by type of treatment. Only two comparisons were addressed by more than one study and allowed pooling of study data: topical imiquimod versus vehicle cream (four studies), and imiquimod versus potassium hydroxide (two studies). For each comparison we have only reported the outcomes that were addressed in the included studies. If an outcome is not reported on, this is because the outcome was not assessed by the study/studies within that comparison.

Where included studies used the term 'complete clearance' or 'free of lesions' or 'cured or $>90 \%$ cleared', we classed these as our primary outcome 'short-term clinical cure (up to three months after start of treatment)' or our secondary outcome 'mediumand long-term cure (after three months and up to six months, and after six months, respectively)', and where they referred to 'partial clearance', we took this to mean our secondary outcome 'improvement'.

We could not include the results of the study by Hanna and colleagues in the analysis, as the outcome (cure rate) was reported only in number of visits, without stating at what time these visits took place (Hanna 2006). Four studies did not report adverse or side effects (Antony 2001; Leslie 2005; Manchanda 1997b; Ohkuma 1990). One study reported the rates but not the nature of the adverse effects (Hanna 2006).

See Summary of findings for the main comparison for our grading of the evidence for the comparison 'imiquimod versus vehicle'.

\section{Topical treatments}

Two of our secondary outcomes were not reported in any of the studies: 6 . Spread to other people and 7. Disease-related quality of life. Only five studies reported on our secondary outcome 3. Time to cure (Eichenfield 2005; Paller 2005b; Ohkuma 1990; Ormerod 1999; Short 2006). With regard to our secondary outcome 5. Adverse effects of treatment such as pain, blistering, sensitisation, scarring, erosion, and pigmentary changes, three studies reported separately on: any side effect, application site reactions, and severe application site reactions (Eichenfield 2005; Paller 2005a; Paller 2005b).

\section{Imiquimod versus vehicle}

The quality of the evidence for this comparison was moderate to high, depending on the outcome; see Summary of findings for the main comparison for details.

\section{Primary outcomes}

1. Short-term clinical cure (up to three months after the start of treatment)

Application of $5 \%$ imiquimod cream resulted in complete clearance in $79 / 544$ participants versus $36 / 306$ of the control group, who 
received vehicle cream (4 studies, 850 participants, risk ratio (RR) 1.33 , 95\% confidence interval (Cl) 0.92 to 1.93 , moderatequality evidence for little or no difference, Analysis 1.1) (time point: 12 weeks after start of treatment) (Eichenfield 2005; Paller 2005a; Paller 2005b; Theos 2004). The pooled analysis showed no heterogeneity $\left(I^{2}=0 \%\right)$.

\section{Secondary outcomes}

\section{Medium- and long-term cure (after three months and up to six} months, and beyond six months, respectively)

Eighteen weeks after start of treatment, application of $5 \%$ imiquimod cream resulted in complete clearance in 112/470 participants versus $63 / 232$ participants in the control (vehicle) group ( 2 studies, RR $0.88,95 \% \mathrm{Cl} 0.67$ to $1.14, \mathrm{I}^{2}=0 \%$, moderatequality evidence for no clear difference, Analysis 1.2) (Eichenfield 2005; Paller 2005b).

Twenty-eight weeks after start of treatment, application of $5 \%$ imiquimod cream resulted in complete clearance in 180/470 participants versus $92 / 232$ participants in the control (vehicle) group ( 2 studies, RR $0.97,95 \% \mathrm{Cl} 0.79$ to $1.17, \mathrm{I}^{2}=0 \%$, moderatequality evidence for no difference, Analysis 1.3) (Eichenfield 2005; Paller 2005b).

\section{Improvement}

Twelve weeks after start of treatment, application of $5 \%$ imiquimod cream resulted in partial or complete clearance in $273 / 544$ participants versus 149/306 participants in the control (vehicle) group (4 studies, RR $1.14,95 \% \mathrm{Cl} 0.89$ to 1.47 , high-quality evidence for little or no difference, Analysis 1.4) (Eichenfield 2005; Paller 2005a; Paller 2005b; Theos 2004). The $I^{2}$ value was $65 \%$, showing substantial heterogeneity. Exploring heterogeneity, in the forest plot the small study Theos 2004 showed as a clear outlier. Excluding this study reduced $\mathrm{I}^{2}$ to $10 \%$, and resulted in a small change of the pooled outcome (RR $1.05,95 \% \mathrm{Cl} 0.91$ to 1.21 ).

Eighteen weeks after start of treatment, application of $5 \%$ imiquimod cream resulted in partial or complete clearance in $341 / 470$ participants versus $174 / 232$ participants in the control (vehicle) group (2 studies, RR $0.97,95 \% \mathrm{Cl} 0.87$ to $1.08, \mathrm{I}^{2}=26 \%$, high-quality evidence for no difference, Analysis 1.5) (Eichenfield 2005; Paller 2005b).

\section{Time to cure}

In two unpublished studies, the median time to cure was the same in the group treated with $5 \%$ imiquimod and the group treated with its vehicle: 16 weeks in Eichenfield 2005 and 18 weeks in Paller 2005b (high-quality evidence).

\section{Recurrence}

In two unpublished studies, recurrence was observed in $1 / 52$ and $3 / 60$ in the group treated with $5 \%$ imiquimod and $0 / 28$ and $0 / 35$ in the group treated with its vehicle after 28 weeks (Eichenfield 2005 and Paller 2005b, respectively) (RR $2.70,95 \% \mathrm{Cl} 0.31$ to $23.23, \mathrm{I}^{2}=$ $0 \%$, moderate-quality evidence, Analysis 1.6 ).

\section{Adverse effects of treatment such as pain, blistering, sensitisation,} scarring, erosion, and pigmentary changes

Three of the four related studies comparing topical 5\% imiquimod with vehicle reported extensively on adverse effects (Eichenfield 2005; Paller 2005a; Paller 2005b); we had copies of the full trial reports of the 3M studies as submitted to the US Food and Drug Administration. In the imiquimod group of Theos 2004, pruritis was reported by $6 / 12$ participants versus $5 / 11$ in the vehicle group. Pain/ tenderness was reported by one participant in each group. Other reported side effects were not interpretable because of unclear denominators.

In Eichenfield 2005, any side effect was reported in 149/217 versus $78 / 106$ participants in the $5 \%$ imiquimod and vehicle group, respectively; application site reactions were reported in $77 / 217$ versus 21/106 participants; 7 versus 1 of these were qualified as severe. In Paller 2005a, any side effect was reported in 42/62 versus $41 / 63$ participants in the $5 \%$ imiquimod and vehicle group, respectively; application site reactions were reported in $32 / 62$ versus 25/63 participants; 6 versus 1 of these were qualified as severe. In Paller 2005b, any side effect was reported in 166/253 versus $84 / 126$ participants in the $5 \%$ imiquimod and vehicle group, respectively; application site reactions were reported in 80/253 versus $31 / 126$ participants; 3 versus 0 of these were qualified as severe. We pooled the results of the three $3 \mathrm{M}$ studies, with 827 evaluable participants. For any adverse effect, the pooled RR was $0.97\left(95 \% \mathrm{Cl} 0.88\right.$ to $1.07, \mathrm{I}^{2}=0 \%$, high-quality evidence for no difference, Analysis 1.7). For application site reactions, the pooled RR was $1.41\left(95 \% \mathrm{Cl} 1.13\right.$ to $1.77, \mathrm{I}^{2}=0 \%$, moderate-quality evidence for probably more harm for imiquimod, Analysis 1.8). The proportion of participants experiencing an application site reaction was $189 / 532(36 \%)$ versus $77 / 295(26 \%)$, giving a number needed to treat for an additional harmful outcome (NNTH) of 11 . For severe application site reactions, the pooled RR was $4.33(95 \% \mathrm{Cl} 1.16$ to $16.19, \mathrm{I}^{2}=0 \%$, moderate-quality evidence for probably more harm for imiquimod, Analysis 1.9). The proportion of participants experiencing a severe application site reaction was 16/532 (3\%) versus $2 / 295(0.7 \%)$, giving a NNTH of over 40 .

\section{Imiquimod versus cryospray}

We considered the evidence for all outcomes for this comparison to be of low quality due to small study size and serious risk of bias.

\section{Primary outcomes}

\section{Short-term clinical cure (up to three months after the start of treatment)}

Application of $5 \%$ imiquimod cream resulted in complete clearance in 22/37 participants versus $37 / 37$ participants who received cryospray after 6 weeks (RR $0.60,95 \% \mathrm{Cl} 0.46$ to 0.78 , Analysis 2.1) (Al-Mutairi 2010). (We selected the 6-week time point for this analysis because the 12 -week time point was close to the 16 -week time point - see below).

\section{Secondary outcomes}

1. Medium- and long-term cure (after three months and up to six months, and beyond six months, respectively)

Application of $5 \%$ imiquimod cream resulted in complete clearance in $34 / 37$ participants versus $37 / 37$ participants who received cryospray after 16 weeks (RR $0.92,95 \% \mathrm{Cl} 0.83$ to 1.20 , Analysis 2.2 ) (Al-Mutairi 2010).

\section{Recurrence}

Al-Mutairi 2010 reported 0/37 in the imiquimod group and 3/37 in the cryospray group with recurrence after 5 months (RR 0.14, 95\% $\mathrm{Cl} 0.01$ to 2.67, Analysis 2.3). 
5. Adverse effects of treatment such as pain, blistering, sensitisation, scarring, erosion, and pigmentary changes

In the 5\% imiquimod group of Al-Mutairi 2010, 27/37 participants reported pain during application; 28/37, erythema; 9/37, itching; $5 / 37$, a burning sensation; and $2 / 37$, pigmentary changes. In the cryospray group, 22/37 participants reported pain during application; 34/37, a burning sensation; 18/37, erosions; $17 / 37$, erythema; 11/37, itching; 9/37, vesicles/bullae; 15/37, pigmentary changes; and 8/37, scarring/atrophy.

\section{Imiquimod versus potassium hydroxide}

We considered the evidence for all outcomes for this comparison to be of low quality due to small study size and serious risk of bias.

\section{Primary outcomes}

\section{Short-term clinical cure (up to three months after the start of treatment)}

Two small studies compared 5\% imiquimod cream with $10 \%$ potassium hydroxide (Chathra 2015; Seo 2010), resulting in complete clearance 12 weeks after start of treatment in 18/34 (imiquimod) versus $27 / 33$ (potassium hydroxide) (RR $0.65,95 \% \mathrm{Cl}$ 0.46 to 0.93$)$, favouring $10 \%$ potassium hydroxide $\left(\mathrm{I}^{2}=0 \%\right)$ and resulting in a number needed to treat for an additional beneficial outcome of 3 (Analysis 3.1).

\section{Secondary outcomes}

5. Adverse effects of treatment such as pain, blistering, sensitisation, scarring, erosion, and pigmentary changes.

Two small studies compared 5\% imiquimod cream with $10 \%$ potassium hydroxide (Chathra 2015; Seo 2010). In the $5 \%$ imiquimod group 10/33 participants reported adverse effects (erythema, burning, itching, ulceration, scaling, hypo- and hyperpigmentation), versus $16 / 34$ in the $10 \%$ potassium hydroxide group (RR $0.68,95 \% \mathrm{Cl} 0.25$ to 1.81 , Analysis 3.2 ). The $\mathrm{I}^{2}$ value was 57\%, showing substantial heterogeneity; however, as only two studies were included in the analysis we were unable to investigate heterogeneity.

\section{Lemon myrtle oil versus olive oil}

We considered the evidence for all outcomes for this comparison to be of low quality due to small study size and serious imprecision.

\section{Primary outcomes}

1. Short-term clinical cure (up to three months after the start of treatment)

Application of $10 \%$ lemon myrtle oil resulted in complete disappearance (or reduction of $>90 \%$ of lesions) after three weeks in 9/16 participants versus $0 / 15$ of the control group, who received only the vehicle (olive oil) (RR $17.88,95 \% \mathrm{Cl} 1.13$ to 282.72 , Analysis 4.1) (Burke 2004). The Fisher exact test resulted in a $P$ value of 0.001 .

\section{Secondary outcomes}

5. Adverse effects of treatment such as pain, blistering, sensitisation, scarring, erosion, and pigmentary changes.

Application of $10 \%$ lemon myrtle oil resulted in local redness in 2/16 participants versus $1 / 15$ participants in the control (vehicle) group (Burke 2004).

\section{Benzoyl peroxide versus tretinoin}

We considered the evidence for the outcome for this comparison to be of low quality due to small study size, unknown risk of bias, and imprecision.

\section{Primary outcomes}

1. Short-term clinical cure (up to three months after the start of treatment)

Application of $10 \%$ benzoyl peroxide resulted in complete disappearance of lesions after six weeks in 11/15 participants compared to $5 / 15$ participants who received $0.05 \%$ tretinoin (RR $2.20,95 \% \mathrm{Cl} 1.01$ to 4.79 , Analysis 5.1) (Saryazdi 2004).

\section{Potassium hydroxide versus saline}

We considered the evidence for all outcomes for this comparison to be of low quality due to small study size, serious risk of bias, and imprecision.

\section{Primary outcomes}

\section{Short-term clinical cure (up to three months after the start of treatment)}

The Bazza 2007 study randomised treatments to the right or left side of the body, comparing application of $5 \%$ potassium hydroxide to $0.9 \%$ saline. On both sides of the body, $17 / 20$ participants showed complete clearance. Due to the absence of paired data in the study report, it was impossible to take the split-body design into account in the analysis, therefore we did not pool the study results with those of Short 2006.

Short 2006 made a similar comparison, showing 10\% potassium hydroxide solution to be successful in $7 / 10$ participants $(70 \%)$ compared with $2 / 10(20 \%)$ in the saline group, which was not statistically significant (RR 3.50, 95\% Cl 0.95 to 12.90 , Analysis 6.1). The Fisher exact test resulted in a $\mathrm{P}$ value of 0.07 .

\section{Secondary outcomes}

5. Adverse effects of treatment such as pain, blistering, sensitisation, scarring, erosion, and pigmentary changes

In Short 2006 most participants treated with 10\% potassium hydroxide reported mild stinging, and two participants reported severe stinging, one of whom withdrew. Also, two participants developed post-inflammatory pigmentary changes at the treatment site (unclear in which group). No participants in the saline group withdrew due to side effects.

In Bazza 2007 12/20 participants reported mild to moderate stinging; $2 / 20$, severe stinging; and $2 / 20$, hypopigmentation in the group treated with $5 \%$ potassium hydroxide. In the group receiving topical $0.9 \%$ saline, $8 / 20$ participants reported mild to moderate stinging and $2 / 20$ reported hypopigmentation.

\section{Potassium hydroxide versus potassium hydroxide}

We considered the evidence for all outcomes for this comparison to be of low quality due to small study size, serious risk of bias, and imprecision. 
Primary outcome

\section{Short-term clinical cure (up to three months after the start of treatment)}

Uçmak 2013 compared 2.5\% and 5\% solutions of potassium hydroxide, and found complete clearance in 3/13 versus $8 / 12$ participants after 60 days (RR $0.35,95 \% \mathrm{Cl} 0.12$ to 1.01 , Analysis 7.1 ), in favour of the $5 \%$ solution. Fisher's exact test resulted in a $\mathrm{P}$ value of 0.047 .

\section{Secondary outcomes}

\section{Improvement}

Uçmak 2013 compared $2.5 \%$ and 5\% solutions of potassium hydroxide, and found clinical cure or improvement in $8 / 13$ versus $10 / 12$ participants after 60 days (RR $0.74,95 \% \mathrm{Cl} 0.45$ to 1.22 , Analysis 7.2 ), favouring the $5 \%$ solution.

5. Adverse effects of treatment such as pain, blistering, sensitisation, scarring, erosion, and pigmentary changes

Uçmak 2013 compared 2.5\% and 5\% solutions of potassium hydroxide, and found at least one adverse effect at 15 days in $11 / 13$ versus $11 / 12$ participants; at 60 days: $6 / 13$ versus $5 / 12$, respectively. The most common adverse effect was a burning sensation.

\section{Potassium hydroxide versus salicylic acid plus lactic acid}

We considered the evidence for all outcomes for this comparison to be of low quality due to small study size, serious risk of bias, and imprecision.

\section{Primary outcome}

1. Short-term clinical cure (up to three months after the start of treatment)

Machado 2010 compared $10 \%$ potassium hydroxide to a combination of $14 \%$ salicylic acid plus $14 \%$ lactic acid, and found $14 / 17$ versus $15 / 16$ participants were cured after a maximum of 90 days treatment (RR $0.88,95 \% \mathrm{Cl} 0.68$ to 1.13 , Analysis 8.1 ).

\section{Secondary outcomes}

5. Adverse effects of treatment such as pain, blistering, sensitisation, scarring, erosion, and pigmentary changes.

In the $10 \%$ potassium hydroxide group of Machado 2010, 10/17 participants reported moderate pain; in the group treated with $14 \%$ salicylic acid plus $14 \%$ lactic acid, $8 / 16$ reported mild pain.

\section{Potassium hydroxide versus curettage}

We considered the evidence for all outcomes for this comparison to be of low quality due to small study size, serious risk of bias, and imprecision.

\section{Primary outcome}

\section{Short-term clinical cure (up to three months after the start of} treatment)

Machado 2010 compared $10 \%$ potassium hydroxide to curettage, and found 14/17 versus 15/17 participants were cured after a maximum of 90 days treatment (RR $0.93,95 \% \mathrm{Cl} 0.71$ to 1.24 , Analysis 9.1).

\section{Secondary outcomes}

5. Adverse effects of treatment such as pain, blistering, sensitisation, scarring, erosion, and pigmentary changes

In the $10 \%$ potassium hydroxide group of Machado 2010, 10/17 participants reported moderate pain; in the curettage group, 12/17 reported mild pain.

\section{Potassium hydroxide versus cryotherapy}

We considered the evidence for all outcomes for this comparison to be of low quality due to small study size and serious risk of bias.

Primary outcome

\section{Short-term clinical cure (up to three months after the start of treatment)}

Handjani 2014 compared $10 \%$ potassium hydroxide to cryotherapy, and found $13 / 15$ versus $14 / 15$ participants were cured after a maximum of 4 weeks treatment (RR $0.93,95 \% \mathrm{Cl} 0.73$ to 1.18 , Analysis 10.1).

\section{Secondary outcomes}

\section{Improvement}

Handjani 2014 compared $10 \%$ potassium hydroxide to cryotherapy, and found $14 / 15$ versus $15 / 15$ participants were cured or improved after a maximum of 4 weeks treatment (RR $0.94,95 \% \mathrm{Cl} 0.78$ to 1.12 , Analysis 10.2).

\section{Adverse effects of treatment such as pain, blistering, sensitisation, scarring, erosion, and pigmentary changes}

Handjani 2014 found hyperpigmentation in 4/15 participants ( $10 \%$ potassium hydroxide) and $7 / 15$ (cryotherapy), and hypopigmentation in 6/15 (10\% potassium hydroxide) and 5/15 (cryotherapy).

\section{Povidone iodine versus salicylic acid plaster}

We considered the evidence for all outcomes for this comparison to be of low quality due to small study size, serious risk of bias, and imprecision.

\section{Primary outcome}

\section{Short-term clinical cure (up to three months after the start of treatment)}

Application of $10 \%$ povidone iodine was effective in $3 / 5$ participants (60\%) compared to $7 / 10(70 \%)$ who received salicylic acid plaster alone (RR $0.86,95 \% \mathrm{Cl} 0.38$ to 1.95 , not statistically significant) (Ohkuma 1990) (Analysis 11.1). (Please note that this study did not clearly state when cure was measured but stated "treatment continued as long as necessary, range was 7-64 days, mean 26 days".)

\section{Secondary outcomes}

\section{Time to cure}

Application of $10 \%$ povidone iodine resulted in a mean time to cure of 86 days versus 47 days for the group receiving salicylic acid plaster. 
Povidone iodine versus povidone iodine plus salicylic acid plaster

We considered the evidence for all outcomes for this comparison to be of low quality due to small study size, serious risk of bias, and imprecision.

\section{Primary outcome}

\section{Short-term clinical cure (up to three months after the start of} treatment)

Application of $10 \%$ povidone iodine solution was effective in $3 / 5$ participants (60\%) compared with 20/20 (100\%) who received $10 \%$ povidone iodine plus salicylic acid plaster (RR $0.60,95 \% \mathrm{Cl} 0.30$ to 1.18, Analysis 12.1) (Ohkuma 1990). See note above after results of Analysis 11.1

\section{Secondary outcomes}

\section{Time to cure}

Application of $10 \%$ povidone iodine resulted in a mean time to cure of 86 days versus 26 days for the group receiving $10 \%$ povidone iodine plus salicylic acid plaster.

\section{Povidone iodine plus salicylic acid plaster versus salicylic acid plaster}

We considered the evidence for all outcomes for this comparison to be of low quality due to small study size, serious risk of bias, and imprecision.

\section{Primary outcome}

\section{Short-term clinical cure (up to three months after the start of} treatment)

Application of $10 \%$ povidone iodine solution plus $50 \%$ salicylic acid plaster was effective in curing 20/20 participants (100\%) compared with $7 / 10$ (70\%) who received salicylic acid plaster alone (RR 1.43, $95 \% \mathrm{Cl} 0.95$ to 2.16, Analysis 13.1) (Ohkuma 1990). Fisher's exact test resulted in a $\mathrm{P}$ value of 0.03 . See note above after results of Analysis 11.1.

\section{Secondary outcomes}

\section{Time to cure}

Application of $10 \%$ povidone iodine plus salicylic acid plaster resulted in a mean time to cure of 26 days versus 47 days for the group receiving salicylic acid plaster (Ohkuma 1990).

\section{Cantharidin versus vehicle}

We considered the evidence for all outcomes for this comparison to be of low quality due to small study size and imprecision.

\section{Primary outcome}

\section{Short-term clinical cure (up to three months after the start of treatment)}

Coloe Dosal 2014 compared $0.7 \%$ cantharidin cream to its vehicle, and found $2 / 13$ versus $1 / 16$ participants free of lesions at the end of 5 treatments over 2 months (RR $2.46,95 \% \mathrm{Cl} 0.25$ to 24.21 , Analysis 14.1).

\section{Secondary outcomes}

5. Adverse effects of treatment such as pain, blistering, sensitisation, scarring, erosion, and pigmentary changes

In Coloe Dosal 2014, 3/13 participants reported pain; 12/13, blistering; and $6 / 13$, hypo- or hyperpigmentation in the group treated with $0.7 \%$ cantharidin. In the vehicle group, the same effects were found in $1 / 16,8 / 16$, and none of the participants, respectively.

\section{Salicylic acid versus sodium nitrate in salicylic acid}

We considered the evidence for all outcomes for this comparison to be of low quality due to small study size, serious risk of bias, and imprecision.

\section{Primary outcome}

\section{Short-term clinical cure (up to three months after the start of treatment)}

Treatment with $5 \%$ sodium nitrite co-applied daily with $5 \%$ salicylic acid under occlusion resulted in significantly more participants with complete resolution of lesions three months after start of treatment: $12 / 16(75 \%)$ compared with $3 / 14(21 \%)$ participants in the control group, which was treated with an identical cream but omitting sodium nitrite (RR $3.50,95 \% \mathrm{Cl} 1.23$ to 9.92, Analysis 15.1) (Ormerod 1999).

5. Adverse effects of treatment such as pain, blistering, sensitisation, scarring, erosion, and pigmentary changes

In the group treated with 5\% sodium nitrite co-applied with 5\% salicylic acid under occlusion, brown staining was reported in 6 of the 16 participants (Ormerod 1999). Four out of 16 participants $(25 \%)$ in this group stopped the treatment because of irritation and lack of efficacy. Two additional participants, who were cured, complained of significant irritation. In the group treated with $5 \%$ salicylic acid only, 4/14 participants complained of irritation.

\section{Salicylic acid versus alcohol}

We considered the evidence for all outcomes for this comparison to be of low quality due to small study size, serious risk of bias, and imprecision.

\section{Secondary outcomes}

1. Medium- and long-term cure (after three months and up to six months, and beyond six months, respectively)

As part of a three-arm study, Leslie 2005 compared $12 \%$ salicylic acid with $70 \%$ alcohol, and assessed cure after a maximum of 6 months. In the $12 \%$ salicylic acid group, $21 / 37$ participants were cured versus $16 / 36$ in the $70 \%$ alcohol group (RR $1.28,95 \% \mathrm{Cl} 0.81$ to 2.02 , Analysis 16.1 ).

\section{Salicylic acid versus phenol plus alcohol}

We considered the evidence for all outcomes for this comparison to be of low quality due to small study size, serious risk of bias, and imprecision. 


\section{Secondary outcomes}

1. Medium- and long-term cure (after three months and up to six months, and beyond six months, respectively)

As part of a three-arm study, Leslie 2005 compared 12\% salicylic acid with $10 \%$ phenol plus $70 \%$ alcohol, and assessed cure after a maximum of 6 months. In the $12 \%$ salicylic acid group, $21 / 37$ participants were cured versus $17 / 41$ in the $10 \%$ phenol plus $70 \%$ alcohol group (RR $1.37,95 \% \mathrm{Cl} 0.86$ to 2.17 , not statistically significant, Analysis 17.1).

\section{Salicylic acid plus lactic acid versus curettage}

We considered the evidence for all outcomes for this comparison to be of low quality due to small study size, serious risk of bias, and imprecision.

\section{Primary outcome}

1. Short-term clinical cure (up to three months after the start of treatment)

The third comparison of Machado 2010 was a combination of $14 \%$ salicylic acid plus 14\% lactic acid versus curettage, resulting in $14 / 17$ versus $15 / 17$ participants showing complete clearance (RR $1.06,95 \% \mathrm{Cl} 0.86$ to 1.32 , Analysis 18.1 ).

\section{Secondary outcomes}

5. Adverse effects of treatment such as pain, blistering, sensitisation, scarring, erosion, and pigmentary changes

In the group treated with $14 \%$ salicylic acid plus $14 \%$ lactic acid, 8/16 participants reported mild pain, whereas in the curettage group $12 / 17$ reported mild pain.

\section{Alcohol versus phenol plus alcohol}

We considered the evidence for all outcomes for this comparison to be of low quality due to small study size, serious risk of bias, and imprecision.

\section{Secondary outcomes}

1. Medium- and long-term cure (after three months and up to six months, and beyond six months, respectively)

As part of a three-arm study, Leslie 2005 compared $70 \%$ alcohol plus $10 \%$ phenol with $70 \%$ alcohol, and assessed cure after a maximum of 6 months. In the $70 \%$ alcohol group, 16/36 participants were cured versus $17 / 41$ in the $70 \%$ alcohol plus $10 \%$ phenol group (RR $1.07,95 \% \mathrm{Cl} 0.64$ to 1.79 , Analysis 19.1).

\section{lodine versus tea tree oil}

We considered the evidence for all outcomes for this comparison to be of low quality due to small study size, serious risk of bias, and imprecision.

\section{Primary outcome}

\section{Short-term clinical cure (up to three months after the start of} treatment)

In a three-armed study, Markum 2012 compared iodine, tea tree oil, and the two combined. Application of iodine compared to tea tree oil resulted in clinical cure ( $>90 \%$ reduction of lesions) in $1 / 16$ versus $3 / 18$ participants (RR $0.38,95 \% \mathrm{Cl} 0.04$ to 3.25 , Analysis 20.1 ).

\section{Secondary outcomes}

\section{Improvement}

Application of iodine compared to tea tree oil resulted in clinical improvement in $5 / 16$ versus $8 / 18$ participants (RR $0.70,95 \% \mathrm{Cl} 0.29$ to 1.71 , Analysis 20.2) (Markum 2012).

5. Adverse effects of treatment such as pain, blistering, sensitisation, scarring, erosion, and pigmentary changes

Redness was reported in 2/16 participants treated with iodine and $1 / 18$ participants treated with tea tree oil. None of the iodinetreated participants and 4/18 participants treated with tea tree oil noted a sensation of warmth during application (Markum 2012).

\section{lodine versus iodine plus tea tree oil}

We considered the evidence for all outcomes for this comparison to be of low quality due to small study size and imprecision.

\section{Primary outcome}

\section{Short-term clinical cure (up to three months after start of treatment)}

In a three-armed study, Markum 2012 compared iodine, tea tree oil, and the two combined. Application of iodine compared to tea tree oil combined with iodine resulted in $>90 \%$ reduction of lesions in $1 / 16$ versus $16 / 19$ participants (RR $0.07,95 \% \mathrm{Cl} 0.01$ to 0.50 , Analysis 21.1).

\section{Secondary outcomes}

\section{Improvement}

Application of iodine compared to tea tree oil combined with iodine resulted in improvement in $5 / 16$ versus $18 / 19$ participants (RR 0.29 , $95 \% \mathrm{Cl} 0.14$ to 0.62 , Analysis 21.2 ).

5. Adverse effects of treatment such as pain, blistering, sensitisation, scarring, erosion, and pigmentary changes

Redness was reported in 2/16 participants treated with iodine and $1 / 19$ participants treated with iodine combined with tea tree oil. None of the iodine-treated participants and 3/19 participants treated with the combination noted a sensation of warmth during application (Markum 2012).

\section{Tea tree oil versus iodine plus tea tree oil}

We considered the evidence for all outcomes for this comparison to be of low quality due to small study size and imprecision.

\section{Primary outcome}

\section{Short-term clinical cure (up to three months after start of treatment)}

Application of tea tree oil alone compared to iodine combined with tea tree oil resulted in $>90 \%$ reduction of lesions in $3 / 18$ versus $16 / 19$ participants (RR $0.20,95 \% \mathrm{Cl} 0.07$ to 0.57 , Analysis 22.1) (Markum 2012), favouring the combined treatment.

\section{Secondary outcomes}

\section{Improvement}

Application of tea tree oil alone compared to iodine combined with tea tree oil resulted in improvement in $8 / 18$ versus $18 / 19$ participants (RR $0.47,95 \% \mathrm{Cl} 0.28$ to 0.79 , Analysis 22.2) (Markum 2012), favouring the combined treatment. 
5. Adverse effects of treatment such as pain, blistering, sensitisation, scarring, erosion, and pigmentary changes

Redness was reported in $1 / 18$ participants treated with tea tree oil and $1 / 19$ participants treated with the combination. The number of participants noting a sensation of warmth during application was $4 / 18$ and 3/19 treated with tea tree oil or the combination (Markum 2012).

\section{Systemic treatments}

Of the two studies addressing systemic treatments, only one study reported on our primary outcome but did not include any of our secondary outcomes (Manchanda 1997b). The other study reported on two of our secondary outcomes (Antony 2001).

\section{Cimetidine versus placebo}

We considered the evidence for all outcomes for this comparison to be of low quality due to small study size, serious risk of bias, and imprecision.

\section{Secondary outcomes}

1. Medium- and long-term cure (after three months and up to six months, and beyond six months, respectively)

Treatment with systemic cimetidine $35 \mathrm{mg} / \mathrm{kg} /$ day cleared lesions completely in $4 / 8$ participants (50\%) after 4 months of treatment, compared with $5 / 11$ participants (46\%) given placebo in the same period (Analysis 23.1) (Antony 2001). The difference was not statistically significant (RR $1.10,95 \% \mathrm{Cl} 0.43$ to 2.84 ). No data were reported for the $50 \%$ (19/38) of participants who withdrew from the study.

\section{Improvement}

Treatment with systemic cimetidine $35 \mathrm{mg} / \mathrm{kg} /$ day resulted in completely cleared lesions or self reported improvement in $7 / 8$ participants after 4 months of treatment, compared with 9/11 participants given placebo in the same period (Analysis 23.2) (Antony 2001). The difference was not statistically significant (RR $1.07,95 \% \mathrm{Cl} 0.73$ to 1.57$)$.

\section{Calcarea carbonica versus placebo}

We considered the evidence for all outcomes for this comparison to be of low quality due to small study size, serious risk of bias, and imprecision.

\section{Primary outcome}

\section{Short-term clinical cure (up to three months after start of treatment)}

Treatment with calcarea carbonica resulted in $100 \%$ improvement in $13 / 14$ participants in the treatment arm and $1 / 6$ in the placebo arm of the trial (RR 5.57, 95\% Cl 0.93 to 33.54, Analysis 24.1) (Manchanda 1997b). Fisher's exact test resulted in a $\mathrm{P}$ value of 0.002 . However, study duration, time to resolution, and adverse events were not reported, and the study was not analysed by the intention-to-treat principle. The number of dropouts (20/104 for the whole trial, including other skin conditions) was unclear for the molluscum participants.

\section{DISCUSSION}

\section{Summary of main results}

Twenty-two studies, with a total of 1650 participants, examined the effects of topical ( 20 studies) and systemic ( 2 studies) interventions. Altogether, we could extract evaluable data for 24 comparisons.

We found limited evidence of low quality from 11 comparisons for the short-term cure efficacy of the following topical treatments: cryospray when compared to $5 \%$ imiquimod; $10 \%$ potassium hydroxide compared to $5 \%$ imiquimod; $5 \%$ sodium nitrite coapplied with $5 \%$ salicylic acid compared to $5 \%$ salicylic acid alone; tea tree oil combined with iodine compared to tea tree oil or iodine alone; $10 \%$ Australian lemon myrtle oil compared to olive oil; and $10 \%$ benzoyl peroxide compared to $0.05 \%$ tretinoin. We found some evidence to suggest that $10 \%$ potassium hydroxide is more effective than saline; $5 \%$ solution of potassium hydroxide is favoured compared to $2.5 \%$ solution of potassium hydroxide; $10 \%$ povidone iodine solution plus $50 \%$ salicylic acid plaster is favoured compared to salicylic acid plaster alone; and homeopathic calcarea carbonica is favoured compared to placebo. We found no statistically significant differences for the other comparisons not including imiquimod.

The addition of three unpublished trial reports, with a total of over 800 participants, resulted in high- to moderate-quality evidence for the comparison of topical $5 \%$ imiquimod versus vehicle. We conclude that compared to vehicle, topical $5 \%$ imiquimod is probably no more effective in terms of clinical cure, makes little or no difference in terms of short-term improvement or local side effects, but appears to induce more application site reactions.

Overall, study limitations included lack of blinding, many dropouts, and no intention-to-treat analysis. Small study sizes resulted in broad confidence intervals and may have led to important differences being missed. None of the evaluated treatment options were associated with serious adverse effects, except for $5 \%$ imiquimod (severe application site reactions).

Although this update of our original review identified 11 new studies for inclusion, the overall conclusions have hardly changed, due to the small size of most of the studies and methodological shortcomings. We found no strong evidence either for or against the most commonly used treatment options for molluscum contagiosum. The evidence identified by this systematic review is therefore insufficient to propose any one intervention for molluscum contagiosum.

\section{Overall completeness and applicability of evidence}

Of the 11 trials added during the 2016 update, only three contributed to comparisons for which trials had been found in previous versions of this review. The other eight addressed new comparisons, thus increasing the fragmentation of the evidence. There remains an evidence gap regarding many promoted and used treatment options for molluscum contagiosum, with many interventions assessed by single, low-quality studies. For example, of the two studies that included a curettage arm (Hanna 2006; Machado 2010), the outcomes of Hanna 2006 were not suitable for inclusion in this review, and Machado 2010 was a very small study, with 50 participants divided over three study arms. We could include only two studies on cryotherapy (Al-Mutairi 2010; Handjani 2014). 
Due to the small sample sizes of the low-quality, single-study comparisons that were included and for which no differences were found, it is possible that clinically relevant differences could be found if treatments would be evaluated in larger samples.

About half of the studies did not compare an active treatment to some sort of placebo, but rather compared two active treatments. This implies that for these interventions, the magnitude of benefit compared to placebo or doing nothing is unclear.

Several issues remain unclear due to lack of details in the published papers. For example, it is unclear whether duration of treatment, as used in Ormerod 1999, can be taken as a valid indicator for time to cure given dropouts and other possible reasons for stopping treatment. Although Antony 2001 did not report on adverse events, the $50 \%$ loss to follow-up rate in the trial might have been caused by adverse effects of the treatment. It is unclear which dosing regimen was used in Manchanda 1997b when evaluating calcarea carbonica.

Several of the outcomes important to participants and clinicians were not measured in most of the studies we found, or not at all; these included recurrences, and, especially, spread to other people and quality of life.

We initially chose our primary outcome measure to be clinical cure after one month, calculated from the last day of treatment. However, this may not be the most appropriate outcome measure to cover the variety of treatments for molluscum. For example, when comparing a method of physical destruction (e.g. curettage) with a topical treatment that is applied during several days or weeks, our primary outcome measure might favour the first type of treatment. For this update we have adapted our primary outcome to make it more manageable: short-term clinical cure (up to three months after start of treatment). A time point beyond one month after start of treatment for assessing cure was also suggested by Mc Cuaig 2011, commenting on the 2009 update of this review. An example of when time to cure since the last day of treatment is not appropriate is when treatment is continued until resolution of all lesions (e.g. Ohkuma 1990). Although no clear-cut solution seems available, and so far few trials have studied physical destruction (e.g. Hanna 2006; Machado 2010), it is advisable to always consider multiple outcome measures and also to take the burden of treatment into account.

We could perform a meta-analysis for only two comparisons: $5 \%$ imiquimod versus its vehicle and $5 \%$ imiquimod versus $10 \%$ potassium hydroxide.

We excluded studies on genital molluscum contagiosum and in participants with immune deficiency, so our conclusions do not apply to these participant groups, as the need for treatment is probably higher and may require different treatments.

\section{Quality of the evidence}

We included 22 studies with a total of 1650 participants in this update. Most of the included studies had small sample sizes, with a median study size of just over 30 molluscum participants, and only five studies with more than 100 participants. This impacted on our GRADE assessments. The small studies may have limited power, which was reflected in the wide confidence intervals around the risk ratios. In addition, many of the studies had large losses to followup, up to $50 \%$ (Antony 2001).
Furthermore, most of the included studies used a control treatment that was not a placebo. Examples of comparator treatments in these studies were olive oil, saline, and alcohol, which may have had potential treatment effects. It was therefore difficult to compare the net effect of interventions due to the absence of a placebo group.

We could assign a low risk of bias for only a small proportion of items in the 'Risk of bias' table (Figure 2). The lack of reported details on several methodological issues and follow-up periods, together with the small number of participants, gives rise to doubts about the validity of the results of some of the studies. We were not able to assess publication bias in this review, for example by constructing a funnel plot, due to the lack of directly comparable studies.

Notably, we judged five of the nine studies included in the 2016 update to be at low risk of bias (Coloe Dosal 2014; Eichenfield 2005; Markum 2012; Paller 2005a; Paller 2005b), suggesting a trend toward better study design or reporting, or both. However, with the exception of the three 'imiquimod versus vehicle' studies, most of the studies added during this update were small. The imiquimod studies overall had a low risk of bias (Eichenfield 2005; Paller 2005a; Paller 2005b; Theos 2004), therefore we did not downgrade the outcomes in Summary of findings for the main comparison for this domain.

As most of the evidence included in this review was based on low-quality studies, we were unable to reach a robust conclusion regarding the objective of the review.

\section{Potential biases in the review process}

Despite conducting a thorough search, we cannot be certain that we did not miss relevant randomised trials. One study is ongoing, and several others are awaiting classification and have not yet been incorporated into the review. Given that 19 of the included studies were performed or published, or both after 2000, we expect more studies comparing treatments for molluscum contagiosum to be published in the coming years.

We made several amendments to the original protocol, some of which were 'data-driven' in the sense that we encountered situations that we had not expected when we developed the protocol. This may have introduced bias.

\section{Agreements and disagreements with other studies or reviews}

At the time of the 2009 update of this review, we had found one other systematic review (Schmitt 2008). This review included six randomised trials, all of which were also included in our review. The conclusions of this review were similar to ours. During the 2016 update, we identified a new partly systematic (they described their databases, search strategy, and search date, but did not select studies or extract data in couples, did not state clear inclusion criteria, and did not assess risk of bias) review (Chen 2013), which addressed not only epidemiology, virology, and immunology of molluscum contagiosum, but also clinical management. They summarised the findings of the previous version of this review (Van der Wouden 2009), and mentioned three new trials (Al-Mutairi 2010; Köse 2013; Seo 2010), the first two of which have been included in this update, and the last which is awaiting assessment. They concluded that no evidence-based consensus has been reached on 
which is the best treatment for molluscum contagiosum in people without immune deficiency.

The cure rates found in the non-randomised study by Weller 1999 for physical expression and phenol ablation $(75 \%$ and $77 \%$ of lesions, respectively, after one month) compare favourably to the $23 \%$ of children found cured in the Japanese cohort study on the natural history of the disease (Takemura 1983).

In the vehicle group of the $3 \mathrm{M}$ studies, clearance rates were $12 \%$ within 3 months; $27 \%$ after 3 to 6 months; and $40 \%$ beyond 6 months. Another, more recent cohort study from the UK (Olsen 2015), where only a small proportion of children were reported to have received treatment, found somewhat lower cure rates: around $10 \%$ after 6 months; $40 \%$ after 12 months; $75 \%$ after 18 months; and $80 \%$ after 24 months. Comparing these figures, 'vehicle' seems to work better than no treatment at all.

\section{AUTHORS' CONCLUSIONS}

\section{Implications for practice}

We can provide no reliable evidence-based recommendations for the treatment of molluscum contagiosum at present, except for $5 \%$ imiquimod, which based on moderate-quality evidence from three unpublished studies is probably no more effective in terms of clinical cure than its vehicle but is probably more harmful in terms of applications site reactions, and based on high-quality evidence is no more effective than its vehicle in terms of short-term improvement.

We found only a few randomised controlled trials that addressed physical destruction of molluscum lesions; these studies were small and at serious risk of bias. Until robust evidence emerges for effective and safe treatment, expectant management, that is awaiting spontaneous resolution of the molluscum lesions, remains a strong option for treating the condition. The studies in Studies awaiting classification may alter the conclusions of the review once assessed.

\section{Implications for research}

Additional well-designed, adequately powered, and preferably blinded randomised controlled studies are needed to provide highquality clinical trial evidence upon which to base clinical decisionmaking. Future studies evaluating treatments for molluscum contagiosum should, as a priority, focus on commonly promoted and commonly used options for treatment (e.g. curettage, cryotherapy, salicylic acid) and preferably include a placebo or vehicle arm as long as no high-quality evidence supporting a treatment option is available. When comparing different types of treatments, the use of the double-dummy technique should be considered where possible. Regarding sample sizes, we suggest following GRADE guidance for information size (www.gradeworkinggroup.org).

Limited data on the natural history of molluscum contagiosum is available. Additional studies into the rate of resolution without active interventions are therefore needed, preferably assessing this after various follow-up times (e.g. 1, 3, 6, and 12 months). This will help guide decisions concerning the use of active treatments.
Outcome measures of future trials should not only include cure, but also recurrence rates, spread of the disease to other people, disease-related quality of life, and scarring.

A standardised outcome measure (e.g. time to resolution of the lesions or resolution after three months) would make studies easier to compare. However, the difference in the nature of treatments, for example repeated topical application of a chemical substance versus physical destruction of the lesions, will probably hamper the harmonisation of timing of outcome measurement.

Statistical power must be considered in conjunction with outcomes that are meaningful for people with molluscum contagiosum. For example, it is likely that a treatment that results in statistically fewer lesions may not be considered worthwhile because this reduction may not be sufficient to improve appearance or quality of life. People should be able to weigh costs and benefits, taking into account resolution of lesions, adverse effects, and treatment burden.

Molluscum contagiosum is a common disease in people with immune deficiency (e.g. people living with HIV). There is also a sexually transmitted variant that affects sexually active people without immune deficiency, which we excluded from this review. There is a need for reviews of studies of treatments for these important subgroups of people with molluscum contagiosum.

\section{ACKNOWLEDGEMENTS}

The authors thank Marjolein Berger, Chris Butler, Sanjay Gajadin, Jack Menke, and Marjolein Tasche for their involvement in writing previous versions of our review. The authors would also like to thank Adrie Hollestein, Ken Katz, Daan Muris, Kazutomo Ohkuma, Anthony Ormerod, Jane Sterling, and Hywel Williams for drawing our attention to relevant studies.

Drs. Manchanda, Kazutomo Ohkuma, and Anthony Ormerod kindly provided additional information regarding their studies, and Kate Short and Mohammed Bazza generously sent us their full paper before it was submitted for publication. Derya Uçmak kindly sent us their paper. The editorial base provided help in tracing and translating papers. We also thank Himiko Luiken for translating the unique study on the natural history of molluscum contagiosum (Takemura 1983), and Taixiang Wu for interviewing $\mathrm{Dr} \mathrm{He}$ on details of her study design (He 2001). We thank Alireza Firooz for assessing the paper Salmanpour 2006, and Susheera Chatpoedprai for providing additional information on their study (Chatproedrai 2007). Clemens van Ede (at that time medical director of Meda Pharma BV, Netherlands) kindly provided the trial reports of the three unpublished 3M studies (Eichenfield 2005; Paller 2005a; Paller 2005b).

For the current update of this review, the Cochrane Skin editorial base wishes to thank Bob Boyle, Cochrane Dermatology Editor for this review; Matthew Grainge, Statistical Editor; Ching-Chi Chi, Methods Editor; the clinical referees, Paul Martin and Hywel Williams; and the consumer referee, Jack Tweed; as well as Lisa Winer, who copy edited the review. 
RE FE RE N CES

\section{References to studies included in this review}

Al-Mutairi 2010 \{published data only\}

Al-Mutairi N, Al-Doukhi A, Al-Farag S, Al-Haddad A. Comparative study on the efficacy, safety, and acceptability of imiquimod $5 \%$ cream versus cryotherapy for molluscum contagiosum in children. Pediatric Dermatology 2010;27(4):388-94. [CENTRAL: CN-00760650; PUBMED: 19804497]

\section{Antony 2001 \{published data only\}}

Antony F, Cliff S, Ahmad A, Holden C. Double-blind placebocontrolled study of oral cimetidine treatment for molluscum contagiosum. British Journal of Dermatology 2001;145(Suppl 59):126. [CENTRAL: CN-00430863]

\section{Bazza 2007 \{unpublished data only\}}

* Bazza MA, Ryatt KS. Sterile normal 0.9\% saline as a effective $5 \%$ potassium hydroxide in treatment of molluscum contagiosum, and safer (title incomplete). Unpublished manuscript 2007:1-4. [CENTRAL: CN-00747643]

\section{Burke 2004 \{published data only\}}

Burke BE, Baillie JE, Olson RD. Essential oil of Australian lemon myrtle (Backhousia citriodora) in the treatment of molluscum contagiosum in children. Biomedecine \& Pharmacotherapie [Biomedicine \& Pharmacotherapy] 2004;58(4):245-7. [CENTRAL: CN-00489728; PUBMED: 15183850]

\section{Chathra 2015 \{published data only\}}

Chathra N, Sukumar D, Bhat RM, Kishore BN, Martis J, Kamath $\mathrm{G}$, et al. A comparative study of $10 \% \mathrm{KOH}$ solution and $5 \%$ imiquimod cream for the treatment of molluscum contagiosum in the pediatric age group. Indian Dermatology Online Journal 2015;6(2):75-80. [CTRI/2013/08/003941; PUBMED: 25821725]

\section{Coloe Dosal 2014 \{published data only\}}

Coloe Dosal J, Stewart PW, Lin JA, Williams CS, Morrell DS. Cantharidin for the treatment of molluscum contagiosum: a prospective, double-blinded, placebo-controlled trial. Pediatric Dermatology 2014;31(4):440-9. [CENTRAL: CN-00999446; PUBMED: 22897595]

\section{Eichenfield 2005 \{unpublished data only\}}

Elchenfield LF. Phase-III double-blind vehicle-controlled study of imiquimod cream $5 \%$ for the treatment of molluscum contagiosum in pediatric subjects (3M Pharmaceuticals study number 1494-IMIQ). Unpublished study report. 3M Pharmaceuticals, St. Paul (MN, USA) 2005.

\section{Handjani 2014 \{published data only\}}

Handjani F, Behazin E, Sadati MS. Comparison of $10 \%$ potassium hydroxide solution versus cryotherapy in the treatment of molluscum contagiosum: an open randomized clinical trial. Journal of Dermatological Treatment 2014;25(3):249-50. [CENTRAL: CN-00961439; PUBMED: 23924070]
Hanna 2006 \{published data only\}

* Hanna D, Hatami A, Powell J, Marcoux D, Maari C, Savard P, et al. A prospective randomized trial comparing the efficacy and adverse effects of four recognized treatments of molluscum contagiosum in children. Pediatric Dermatology 2006;23(6):574-9. [CENTRAL: CN-00609029; PUBMED: 17156002]

McCuaig CC, Hatami A, Powell J, Maari C, Marcoux D, Thibeault $\mathrm{H}$. Mollusca contagiosa: what treatment to use when?. Journal of the European Academy of Dermatology and Venereology: JEADV 2005;19(Suppl 2):8. [CENTRAL: $\mathrm{CN}-00602169]$

Leslie 2005 \{published data only\}

Leslie KS, Dootson G, Sterling JC. Does treatment of molluscum contagiosum affect clearance?. British Journal of Dermatology 2004;151(Suppl 68):67. [CENTRAL: CN-00487868]

* Leslie KS, Dootson G, Sterling JC. Topical salicylic acid gel as a treatment for molluscum contagiosum in children. Journal of Dermatological Treatment 2005;16(5-6):336-40. [CENTRAL: CN-00554512; PUBMED: 16428156]

Machado 2010 \{published data only\}

Machado RB, Leal TF, Bonfa R, Werlang ME, Blessmann Weber M. Molluscum contagiosum in children: comparative treatments [Molusco contagioso em crianças: tratamentos comparativos]. Surgical \& Cosmetical Dermatology 2010;2:272-5.

Manchanda 1997b \{published data only\}

Manchanda RK, Mehan N, Bahl R, Atey R. Double blind placebo controlled clinical trials of homeopathic medicines in warts and molluscum contagiosum. Central Council of Research in Homeopathy Quarterly Bulletin 1997;19(3\&4):25-9. [CENTRAL: CN-00478663]

\section{Markum 2012 \{published data only\}}

Markum E, Baillie J. Combination of essential oil of Melaleuca alternifolia and iodine in the treatment of molluscum contagiosum in children. Journal of Drugs in Dermatology 2012;11(3):349-54. [CENTRAL: CN-00880968; PUBMED: 22395586]

\section{Ohkuma 1990 \{published data only\}}

Ohkuma M. Molluscum contagiosum treated with iodine solution and salicylic acid plaster. International Journal of Dermatology 1990;29(6):443-5. [CENTRAL: CN-00269315; PUBMED: 2397974]

\section{Ormerod 1999 \{published data only\}}

Ormerod AD, White MI, Shah SA, Benjamin N. Molluscum contagiosum effectively treated with a topical acidified nitrite, nitric oxide liberating cream. British Journal of Dermatology 1999;141(6):1051-3. [CENTRAL: CN-00274687; PUBMED: $10606851]$

Paller 2005a \{unpublished data only\}

* Paller A. Double-blind vehicle-controlled study of imiquimod cream $5 \%$ in pediatric subjects with molluscum contagiosum 
to evaluate safety and efficacy of daily dosing during 8 weeks of treatment (3M Pharmaceuticals study number 1490-IMIQ). Unpublished study report. 3M Pharmaceuticals, St. Paul (MN, USA) July 2005 (amendment April 2006).

Paller 2005b \{unpublished data only\}

* Paller A. Phase-III double-blind vehicle-controlled study of imiquimod cream $5 \%$, for the treatment of molluscum contagiosum in pediatric subjects (3M Pharmaceuticals study number 1495-IMIQ). Unpublished study report. 3M Pharmaceuticals, St. Paul (MN, USA) November 2005.

\section{Saryazdi 2004 \{published data only\}}

Saryazdi S. The comparative efficacy of benzoyl peroxide $10 \%$ cream and tretinoin $0.05 \%$ cream in the treatment of molluscum contagiosum. Pediatric Dermatology 2004;21(3):399. [CENTRAL: CN-00520460]

\section{Seo 2010 \{published data only\}}

Seo SH, Chin HW, Jeong DW, Sung HW. An open, randomized, comparative clinical and histological study of imiquimod $5 \%$ cream versus $10 \%$ potassium hydroxide solution in the treatment of molluscum contagiosum. Annals of Dermatology 2010;22(2):156-62. [CENTRAL: CN-01046394]

\section{Short 2006 \{published and unpublished data\}}

Short KA, Fuller LC, Higgins EM. Double-blind randomized placebo-controlled trial of the use of topical potassium hydroxide in the treatment of molluscum contagiosum. British Journal of Dermatology 2002;147(Suppl 62):95. [CENTRAL: CN-00487907; CENTRAL: CN-00406990]

Short KA, Fuller LC, Higgins EM. Double-blind, randomised, placebo-controlled trial of the use of topical $10 \%$ potassium hydroxide solution of molluscum contagiosum. Unpublished manuscript.

* Short KA, Fuller LC, Higgins EM. Double-blind, randomized, placebo-controlled trial of the use of topical $10 \%$ potassium hydroxide solution in the treatment of molluscum contagiosum. Pediatric Dermatology 2006;23(3):279-81. [CENTRAL: CN-00570792; PUBMED: 16780480$]$

\section{Theos 2004 \{published data only\}}

* Theos AU, Cummins R, Silverberg NB, Paller AS. Effectiveness of imiquimod cream $5 \%$ for treating childhood molluscum contagiosum in a double-blind, randomized pilot trial. Cutis 2004;74(2):134-8,141-2. [CENTRAL: CN-00491567; PUBMED: $15379366]$

\section{Uçmak 2013 \{published data only\}}

Uçmak D, Akkurt MZ, Kacar SD, Sula B, Arica M. Comparative study of $5 \%$ and $2.5 \%$ potassium hydroxide solution for molluscum contagiosum in children. Cutaneous and Ocular Toxicology 2014;33(1):54-9. [CENTRAL: CN-00982389; PUBMED: 23713782]

\section{References to studies excluded from this review}

Arican 2006 \{published data only\}

Arican 0. Topical treatment of molluscum contagiosum with imiquimod $5 \%$ cream in Turkish children. Pediatrics International 2006;48(4):403-5. [PUBMED: 16911087]

Barton 2002 \{published data only\}

Barton SE, Chard S. Facial molluscum: treatment with cryotherapy and podophyllotoxin. International Journal of STD \& AIDS 2002;13(4):277-8. [PUBMED: 11963912]

Bayerl 2003 \{published data only\}

Bayerl C, Feller G, Goerdt S. Experience in treating molluscum contagiosum in children with imiquimod $5 \%$ cream. British Journal of Dermatolology 2003;149(Suppl 66):25-9. [PUBMED: 14616342]

\section{Caballero 1996 \{published data only\}}

Caballero Martinez F, Plaza Nohales C, Perez Canal C, Lucena Martin MJ, Holgado Catalán M, Olivera Cañadas G. Cutaneous cryosurgery in family medicine: dimethyl ether-propane spray versus liquid nitrogen. Atencion Primaria 1996;18(5):211-6. [PUBMED: 8963007]

\section{Can 2014 \{published data only\}}

Can B, Topaloğlu F, Kavala M, Turkoglu Z, Zindancı I, Sudogan S. Treatment of pediatric molluscum contagiosum with $10 \%$ potassium hydroxide solution. Journal of Dermatological Treatment 2014;25(3):246-8. [PUBMED: 22639976]

\section{Cathcart 2009 \{published data only\}}

Cathcart S, Coloe J, Morrell DS. Parental satisfaction, efficacy, and adverse events in 54 patients treated with cantharidin for molluscum contagiosum infection. Clinical Pediatrics 2009;48(2):161-5. [PUBMED: 18936288]

\section{Chatproedrai 2007 \{published data only\}}

Chatproedrai S, Suwannakarn K, Wananukul S, Theamboonlers A, Poovorawan Y. Efficacy of pulsed dye laser ( $585 \mathrm{~nm}$ ) in the treatment of molluscum contagiosum subtype 1. Southeast Asian Journal of Tropical Medicine \& Public Health 2007;38(5):849-54. [PUBMED: 18041301]

\section{de Waard 1990 \{published data only\}}

de Waard-van der Spek FB, Oranje AP, Lillieborg S, Hop WC, Stolz E. Treatment of molluscum contagiosum using a lidocaine/prilocaine cream (EMLA) for analgesia. Journal of the American Academy of Dermatology 1990;23(4 Pt 1):685-8. [PUBMED: 2229496]

\section{He 2001 \{published data only\}}

$\mathrm{He} \mathrm{H}$, Lu JY, Fang J, et al. Observation on effect of four kinds of therapy for molluscum contagiosum. Chinese Journal of Dermatovenereology 2001;15(5):308-9. [CENTRAL: CN-00454307]

\section{Hengge 2000 \{published data only\}}

Hengge UR, Esser S, Schultewolter T, Behrendt C, Meyer T, Stockfleth E, et al. Self-administered topical 5\% imiquimod for the treatment of common warts and molluscum contagiosum. 
British Journal of Dermatology 2000;143(5):1026-31. [PUBMED: 11069514]

\section{Holt 2011 \{published data only\}}

Holt S, Webster-Longin M, Perrin K, Baker T, Beasley R. The use of honey in the treatment of molluscum contagiosum in children. Presented at World Dermatology Congress, Seoul, Korea. May 2011.

\section{Juhlin 1980 \{published data only\}}

Juhlin L, Evers H, Broberg F. A lidocaine-prilocaine cream for superficial skin surgery and painful lesions. Acta DermatoVenereologica 1980;60(6):544-6. [PUBMED: 6162348]

Lim 2003 \{published data only\}

Lim DS, Egan CA. Insights into a novel treatment for molluscum. Acta Paediatrica 2003;92(2):265-6. [PUBMED: 12710660]

\section{Manchanda 1997a \{published data only\}}

Manchanda RK, Mehan N, Bahl R, Atey R. Double blind placebo controlled clinical trials of homeopathic medicines in warts and molluscum contagiosum. Central Council for Research in Homeopathy Quarterly Bulletin 1997;19(3\&4):25-30. [CENTRAL: $\mathrm{CN}-00478663$ ]

\section{Metkar 2008 \{published data only\}}

Metkar A, Pande S, Khopkar U. An open, nonrandomized, comparative study of imiquimod $5 \%$ cream versus $10 \%$ potassium hydroxide solution in the treatment of molluscum contagiosum. Indian Journal of Dermatology, Venereology and Leprology 2008;74(6):614-8. [PUBMED: 19171985]

\section{Myhre 2008 \{published data only\}}

Myhre PE, Levy ML, Eichenfield LF, Kolb VB, Fielder SL, Meng TC. Pharmacokinetics and safety of imiquimod $5 \%$ cream in the treatment of molluscum contagiosum in children. Pediatric Dermatology 2008;25(1):88-95. [PUBMED: 18304162]

\section{Puri 2009 \{published data only\}}

Puri N. A study on the use of imiquimod for the treatment of genital molluscum contagiosum and genital warts in female patients. Indian Journal of Sexually Transmitted Diseases 2009;30(2):84-8. [PUBMED: 21938126]

\section{Rosdahl 1988 \{published data only\}}

Rosdahl I, Edmar B, Gisslén H, Nordin P, Lillieborg S. Curettage of molluscum contagiosum in children: analgesia by topical application of lidocaine/prilocaine cream (EMLA). Acta DermatoVenereologica 1988;68(2):149-53. [PUBMED: 2453995]

\section{Sadick 2009 \{published data only\}}

Sadick N, Sorhaindo L. A comparative split-face study of cryosurgery and trichloroacetic acid $100 \%$ peels in the treatment of HIV-associated disseminated facial molluscum contagiosum. Cutis 2009;83(6):299-302. [PUBMED: 19681340]

\section{Salmanpour 2006 \{published data only\}}

Salmanpour R, Razmavar MR, Seyf I. Treatment of molluscum contagiosum with griseofulvin or cryotherapy. Iranian Journal of Dermatology 2006;9(1):5. [CENTRAL: CN-00615975]

\section{Schalka 2010 \{published data only\}}

Schalka S, Addor FAS, Silva VDM, Pinto PC, Milan ALK, Pannuti EMB. A randomized, open-label, comparative clinical study for the evaluation of safety, tolerability and analgesic efficacy of two different presentations of topical medication in the treatment of dermatological curettage of molluscum contagiosum in pediatric patients [Estudo clinico randomizado, aberto e comparativo para avaliacao de seguranca, tolerabilidade e eficacia analgesica de duas diferentes apresentacoes de medicamento topico na realizacao de curetagem dermatologica de molusco contagioso em pacientes pediatricos]. Revista Brasileira de Medicina 2010;67(6):201-7. [CENTRAL: CN-00803780]

\section{Simonart 2008 \{published data only\}}

Simonart T, De Maertelaer V. Curettage treatment for molluscum contagiosum: a follow-up survey study. British Journal of Dermatology 2008;159(5):1144-7. [PUBMED: 18795919]

\section{Skinner 2000 \{published data only\}}

Skinner RB Jr, Ray S, Talanin NY. Treatment of molluscum contagiosum with topical $5 \%$ imiquimod cream. Pediatric Dermatology 2000;17(5):420. [PUBMED: 11085678]

\section{Syed 1994 \{published data only\}}

Syed TA, Lundin S, Ahmad M. Topical $0.3 \%$ and $0.5 \%$ podophyllotoxin cream for self-treatment of molluscum contagiosum in males. A placebo-controlled, double-blind study. Dermatology 1994;189(1):65-8. [CENTRAL: CN-00102127; PUBMED: 8003791]

\section{Syed 1998 \{published data only\}}

Syed TA, Goswami J, Ahmadpour OA, Ahmad SA. Treatment of molluscum contagiosum in males with an analog of imiquimod $1 \%$ in cream: a placebo-controlled, double-blind study. Journal of Dermatology 1998;25(5):309-13. [PUBMED: 9640884]

\section{Weller 1999 \{published data only\}}

Weller R, O'Callaghan CJ, MacSween RM, White MI. Scarring in molluscum contagiosum: comparison of physical expression and phenol ablation. BMJ 1999;319(7224):1540. [PUBMED: 10591712]

\section{Yabut-Catalasan 2003 \{published data only\}}

Yabut-Catalasan RO, Paliza AC. 10\% Potassium Hydroxide as treatment for molluscum contagiosum: a doubleblind, placebo-controlled study. Journal of the Philippine Dermatological Society 2003;12(1):28-35. [CENTRAL: CN-00602272]

\section{References to studies awaiting assessment}

Elzawahry 1964 \{published data only\}

El Zawahry M. Virus skin diseases: frequency and trial of antiviral agent. Journal of the Egyptian Medical Association 1963;46:1303-14. [PUBMED: 14162107]

\section{Köse 2013 \{published data only\}}

Köse O, Özmen I, Arca E. An open, comparative study of $10 \%$ potassium hydroxide solution versus salicylic and lactic acid 
combination in the treatment of molluscum contagiosum in children. Journal of Dermatological Treatment 2013;24(4):300-4. [PUBMED: 22214282]

\section{Muzaffar 2014 \{published data only\}}

Muzaffar F, Faiz F. Comparison of $5 \%$ potassium hydroxide with $10 \%$ potassium hydroxide solution in treatment of molluscum contagiosum: comparative study. Journal of Pakistan Association of Dermatologists 2014;24(4):337-41. [www.jpad.org.pk/Oct\%20Dec\%202014/11.\%200riginal \%20article\%20KoH\%20in\%20molluscum\%20contagiosum.pdf]

\section{NCT01348386 \{published data only\}}

NCT01348386. Efficacy and tolerance of potassium hydroxide (10\% and $15 \%$ ) in molluscum contagiosum (EKOH-MOL 2008) [Efficacy and tolerance of the topical application of potassium hydroxide ( $10 \%$ and $15 \%)$ in the treatment of molluscum contagiosum]. clinicaltrials.gov/ct2/show/NCT01348386 Date first received: 4 May 2011.

\section{NCT02665260 \{unpublished data only\}}

NCT02665260. Safety and efficacy study of topical cantharidin for the treatment of molluscum contagiosum [Randomized pilot study investigating the safety and efficacy of topical cantharidin for the treatment of molluscum contagiosum]. clinicaltrials.gov/ ct2/show/NCT02665260 Date first received: 31 December 2016.

\section{Rajouria 2011 \{published data only\}}

Rajouria EA, Amatya A, Karn D. Comparative study of $5 \%$ potassium hydroxide solution versus $0.05 \%$ tretinoin cream for Molluscum Contagiosum in children. Kathmandu University Medical Journal 2011;9(36):291-4. [PUBMED: 22710541]

\section{Tanissa 1951 \{published data only\}}

Tanissa A. 62 cases of molluscum contagiosum in a boardingschool; trial therapy with sulfonamides, podophyllin and aureomycin [Sessenta e dois casos de "molluscum contagiosum" em um internato. Ensaios teraputicos pelas sulfonamidas, podofilina e aureomicina]. Gazeta Médica Portuguesa 1951;4(1):77-83. [ref 44 of Cochrane Skin Group search 2014; PUBMED: 14823272]

\section{Unknown Chinese author 1991 \{published data only\}}

Unknown Chinese author(s). Different concentrations of iodine tincture in the treatment of molluscum contagiosum. Chinese Journal of Dermatology 1991;24(6):405. [ref 1 of Cochrane Skin Group search 2014]

\section{References to ongoing studies}

\section{NCT02024581 \{published data only\}}

NCT02024581. A dose range-finding phase 2 trial of a botanical drug for the treatment of molluscum contagiosum in pediatric subjects [A single-center, double-blind, placebo-controlled, randomized safety and efficacy trial of a botanical drug product, East Indian Sandalwood Oil (EISO), at one dose level for the treatment of molluscum contagiosum in pediatric subjects]. clinicaltrials.gov/ct2/show/NCT02024581 Date first received: 19 December 2013

\section{Additional references}

\section{Back Review Group 2008}

Cochrane Back Review Group. Sources of risk of bias. www.cochrane.iwh.on.ca/pdfs/RoBassessform_June2008.rtf (accessed 3 February 2009).

\section{Barba 2001}

Barba AR, Kapoor S, Berman B. An open label safety study of topical imiquimod $5 \%$ cream in the treatment of molluscum contagiosum in children. Dermatology Online 2001;7(1):20. [PUBMED: 11328641]

\section{Beaulieu 2000}

Beaulieu Ph, Pepin E, Aboucaya P, Bennassy I, Blaise F, Blechaye-Butaye $F$, et al. Molluscum contagiosum. Epidemiological study of 452 cases in private practice [Molluscum contagiosum. Etude épidémiologique de 452 observations en pratique libérale]. Nouvelle Dermatologique 2000;19:231.

\section{Behl 1970}

Behl PN, Bhatia BK. Clinical trial of milkweed (Asclepius curussavica) in the treatment of warts. Indian Journal of Dermatology 1970;15(2):49-50. [PUBMED: 4914368]

\section{Berger 1996}

Berger TG, Tappero JW. Chapter 25 Human immunodeficiency virus infection and the cutaneous complications of immunosuppression. In: Arndt KA, et al. editor(s). Cutaneous medicine and surgery. Vol. 2, Philadelphia: WB Saunders, 1996:1098-9.

\section{Bigardi 2003}

Bigardi A, Milani M. Successful treatment of molluscum contagiosum skin infection with hydrogen peroxide $1 \%$ cream. Journal of the European Academy of Dermatology and Venereology 2003;17(Suppl 3):419.

\section{Brandrup 1989}

Brandrup F, Asschenfeldt P. Molluscum contagiosuminduced comedo and secondary abscess formation. Pediatric Dermatology 1989;6(2):118-21. [PUBMED: 2748472]

\section{Braue 2005}

Braue A, Ross G, Varigos G, Kelly H. Epidemiology and impact of childhood molluscum contagiosum: a case series and critical review of the literature. Pediatric Dermatology 2005;22(4):287-94. [PUBMED: 16060861]

\section{Brown 2006}

Brown J, Janniger CK, Schwartz RA, Silverberg NB. Childhood molluscum contagiosum. Internation Journal of Dermatology 2006;45(2):93-9. [PUBMED: 16445494]

\section{Buller 1991}

Buller RM, Palumbo GJ. Poxvirus pathogenesis. Microbiological Reviews 1991;55(1):80-122. [PUBMED: 1851533] 


\section{Chen 2013}

Chen X, Anstey AV, Bugert JJ. Molluscum contagiosum virus infection. Lancet Infectious Diseases 2013;13(10):877-88. [PUBMED: 23972567]

\section{Coloe 2009}

Coloe J, Morrell DS. Cantharidin use among pediatric dermatologists in the treatment of molluscum contagiosum. Pediatric Dermatology 2009;26(4):405-8. [PUBMED: 19689514]

\section{Cope 1915}

Cope LF. A case of molluscum contagiosum cured by $X$ rays. Lancet 1915;185(4788):1179. [DOI: 10.1016/ S0140-6736(01)66721-7]

\section{Cunningham 1998}

Cunningham BB, Paller AS, Garzon M. Inefficacy of oral cimetidine for nonatopic children. Pediatric Dermatology 1998;15(1):71-2. [PUBMED: 9496815]

\section{Czelusta 2000}

Czelusta A, Yen-Moore A, Van der Straten M, Carrasco D, Tyring SK. An overview of sexually transmitted diseases. Part III. Sexually transmitted diseases in HIV-infected patients. Journal of the American Academy of Dermatology 2000;43(3):409-32. [PUBMED: 10954653]

\section{Davies 1999}

Davies EG, Thrasher A, Lacey K, Harper J. Topical cidofovir for severe molluscum contagiosum. Lancet 1999;353(9169):2042. [PUBMED: 10376628]

\section{Davis 1896}

Davis AE. Report of a case of molluscum contagiosum which got well under the use of yellow oxide of mercury ointment. Annals of Ophthalmology and Otology 1896;5:404.

\section{De Oreo 1956}

Binkley GW, De Oreo GA, Johnson HH. An eczematous reaction associated with molluscum contagiosum. AMA Archives of Dermatology 1956;74(4):344-8. [PUBMED: 13361506]

\section{Dohil 1996}

Dohil M, Prendiville JS. Treatment of molluscum contagiosum with oral cimetidine: clinical experience in 13 patients. Pediatric Dermatology 1996;13(4):310-2. [PUBMED: 8844752]

\section{Friedman 1987}

Friedman M, Gal D. Keloid scars as a result of $\mathrm{CO} 2$ laser for molluscum contagiosum. Obstetrics and Gynecology 1987;70(3 Pt 1):394-6. [PUBMED: 3627587]

\section{Funt 1961}

Funt TR. Canthadirin treatment of molluscum contagiosum. Archives of Dermatology 1961;83:504-5. [PUBMED: 13702631]

\section{Funt 1979}

Funt TR, Mehr KA. Cantharidin: a valuable office treatment of molluscum contagiosum. Southern Medical Journal 1979;72(8):1019. [PUBMED: 472800]

\section{Gao 2016}

Gao YL, Gao XH, Qi RQ, Xu JL, Huo W, Tang J, et al. Clinical evaluation of local hyperthermia at $44^{\circ} \mathrm{C}$ for molluscum contagiosum: pilot study with 21 patients. British Journal of Dermatology 2016 Jul 5 [Epub ahead of print]. [DOI: 10.1111/ bjd.14849; PUBMED: 27377758]

\section{Gottlieb 1994}

Gottlieb SL, Myskowski PL. Molluscum contagiosum. International Journal of Dermatology 1994;33(7):453-61. [PUBMED: 7928025]

\section{Gräfe $\mathbf{2 0 0 0}$}

Gräfe A, Fischer S, Bohn M, Neumann Ch, Kölmel K. Treatment of warts with NO releasing ointment [Die Behandlung von Dellwarzen mit einer NO-freisetzenden Creme (5\% Natriumnitrit and 5\% Zitronensäure in Basiscreme DAC)]. Zeitschrift für Hautkrankheiten 2000;75:492.

\section{Haellmigk 1966}

Haellmigk C. Keratoconjunctivitis in molluscum contagiosum of the eyelids [Keratokonjunktivitis bei Molluscum contagiosum der Lider]. Klinische Monatsblatter fur Augenheilkunde 1966;148(1):87-91. [PUBMED: 5978089]

\section{Hammes 2001}

Hammes S, Greve B, Raulin C. Molluscum contagiosum: treatment with pulsed dye laser. Hautarzt 2001;52(1):38-42. [PUBMED: 11220237]

\section{Hawley 1970}

Hawley TG. The natural history of molluscum contagiosum in Fijian children. Journal of Hygiene 1970;68(4):631-2. [PUBMED: 5276334 ]

\section{Hengge 2003}

Hengge UR, Cusini M. Topical immunomodulators for the treatment of external genital warts, cutaneous warts and molluscum contagiosum. British Journal of Dermatology 2003;149(Suppl 66):15-9. [PUBMED: 14616340]

\section{Higgins 2011}

Higgins JP, Green S (editors). Cochrane Handbook for Systematic Reviews of Interventions Version 5.1.0 (updated March 2011). The Cochrane Collaboration, 2011. Available from handbook.cochrane.org. The Cochrane Collaboration.

\section{Highet 1992}

Highet AS. Molluscum contagiosum. Archives of Disease in Childhood 1992;67(10):1248-9. [PUBMED: 1444521]

\section{Hira 1988}

Hira SK, Wadhawan D, Kamanga J, Kavindele D, Macuacua R, Patil PS, et al. Cutaneous manifestations of human immunodeficiency virus in Lusaka, Zambia. Journal of the American Academy of Dermatology 1988;19(3):451-7. [PUBMED: 2971691]

\section{Holt 2015}

Holt S, Webster-Longin M, Perrin K, Baker T, Beasley R. The use of honey in the treatment of molluscum contagiosum in 
children. Conference abstract, presented at World Dermatology Congress, Seoul, Korea 2011.

\section{Hughes 2013}

Hughes CM, Damon IK, Reynolds MG. Understanding U.S. healthcare providers' practices and experiences with molluscum contagiosum. PLoS One 2013;8(10):e76948. [PUBMED: 24155912]

\section{Hund 1975}

Hund G. Vitamin A-acid therapy of molluscum contagiosa in hemophilia A [Vitamin-A-Säure-Therapie von Mollusca contagiosa bei Haemophilie A]. Zeitschrift fur Hautkrankheiten 1975;50(7):291-2. [PUBMED: 1226947]

\section{Husak 1997}

Husak R, Garbe C, Orfanos CE. Molluscum contagiosum in HIV-Infection. Clinical manifestation, relation to immune status and prognostic value in 39 patients. Der Hautarzt; Zeitschrift fur Dermatologie, Venerologie, und Verwandte Gebiete 1997;48(2):103-7. [PUBMED: 9173055]

\section{Jones 2007}

Jones S, Kress D. Treatment of molluscum contagiosum and herpes simplex virus cutaneous infections. Cutis 2007;79(4 Suppl):11-7. [PUBMED: 17508491]

\section{Kang 2005}

Kang SH, Lee D, Hoon Park J, Cho SH, Lee SS, Park SW. Treatment of molluscum contagiosum with topical diphencyprone therapy. Acta Dermatato-Venereologica 2005;85(6):529-30. [PUBMED: 16396805]

\section{Katz 2013}

Katz KA, Swetman GL. Imiquimod, molluscum, and the need for a better "best pharmaceuticals for children" act. Pediatrics 2013;132(1):1-3. [PUBMED: 23796740]

\section{Katz 2014}

Katz KA. Imiquimod is not an effective drug for molluscum contagiosum. Lancet Infectious Diseases 2014;14(5):372-3. [PUBMED: 24758995]

\section{Katz 2015}

Katz KA. Dermatologists, imiquimod, and treatment of molluscum contagiosum in children: righting wrongs. JAMA Dermatology 2015;151(2):125-6. [PUBMED: 25587702]

\section{Koning 1994}

Koning S, Bruijnzeels MA, van Suijlekom-Smit LW, van der Wouden JC. Molluscum contagiosum in Dutch general practice. British Journal of General Practice 1994;44(386):417-9. [PUBMED: 8790656 ]

\section{Kyu 1993}

Kyu Han K, Koo Il S, Jin Ho C, Kyung Chan P, Hee Chul E. The effect of diphenylcyclopropenone immunotherapy on molluscum contagiosum. Annals of Dermatology 1993;5(2):79-82.

\section{Liota 2000}

Liota E, Smith KJ, Buckley R, Menon P, Skelton H. Imiquimod therapy for molluscum contagiosum. Journal of Cutaneous Medical Surgery 2000;4(2):76-82. [PUBMED: 11179929]

\section{Liveing 1878}

Liveing R. Molluscum contagiosum. Lancet 1878;112(2875):494.

\section{Lowy 1999}

Lowy DR. Molluscum contagiosum. In: Fitzpatrick TB, Freedberg IM editor(s). Fitzpatrick's Dematology in General Medicine. 5th Edition. Vol. 2, New York: McGraw-Hill, 1999:2478-81.

\section{Mansur 2004 \\ Mansur AT, Goktay F, Gunduz S, Serdar ZA. Multiple giant molluscum contagiosum in a renal transplant recipient. Transplant Infectious Disease 2004;6(3):120-3. [PUBMED: 15569228]}

\section{Markos 2001}

Markos AR. The successful treatment of molluscum contagiosum with podophyllotoxin $(0.5 \%)$ self-application. International Journal of STD \& AIDS 2001;12(12):833. [PUBMED: 11791521]

\section{Matis 1987}

Matis WL, Triana A, Shapiro R, Eldred L, Polk BF, Hood AF. Dermatologic findings associated with human immunodeficiency virus infection. Journal of the American Academy of Dermatology 1987;17(5 Pt 1):746-51. [PUBMED: 3680653]

\section{Mc Cuaig 2011}

Mc Cuaig C, Silverberg N. Commentaries on 'Interventions for cutaneous molluscum contagiosum'. Evidence-based Child Health 2011;6:1602-4. [DOI: 10.1002/ebch.833]

\section{Molino 2004}

Molino AC, Fleischer AB Jr, Feldman SR. Patient demographics and utilization of health care services for molluscum contagiosum. Pediatric Dermatology 2004;21(6):628-32. [PUBMED: 15575844]

\section{Niizeki 1984}

Niizeki K, Kano O, Kondo Y. An epidemic study of molluscum contagiosum. Relationship to swimming. Dermatologica 1984;169(4):197-8. [PUBMED: 6500123]

\section{Niizeki 1999}

Niizeki K, Hahimoto K. Treatment of molluscum contagiosum with silver nitrate paste. Pediatric Dermatology 1999;16(5):395-7. [PUBMED: 10571843]

\section{Olsen 2014}

Olsen JR, Gallacher J, Piguet V, Francis NA. Epidemiology of molluscum contagiosum in children: a systematic review. Family Practice 2014;31(2):130-6. [PUBMED: 24297468]

\section{Olsen 2015}

Olsen JR, Gallacher J, Finlay AY, Piquet V, Francis NA. Time to resolution and effect on quality of life of molluscum 
contagiosum in children in the UK: a prospective community cohort study. Lancet Infectious Diseases 2015;15(2):190-5. [PUBMED: 25541478]

\section{Ordoukhanian 1997}

Ordoukhanian E, Lane AT. Warts and molluscum contagiosum: beware of treatments worse than the disease. Postgraduate Medicine 1997;101(2):223-32, 235. [PUBMED: 9046937]

\section{Orlow 1993}

Orlow SJ, Paller A. Cimetidine therapy for multiple viral warts in children. Journal of the American Academy of Dermatology 1993;28(5 Pt 1):794-6. [PUBMED: 8496433]

\section{Overfield 1966}

Overfield TM, Brody JA. An epidemiologic study of molluscum contagiosum in Anchorage, Alaska. Journal of Pediatrics 1966;69(4):640-2. [PUBMED: 5921341]

\section{Papadopoulos 2007}

Papadopoulos EJ. Clinical executive summary. Application type: NDA, Submission number: 20723; Submission code: SE8-020. FDA report March 15, 2007 (electronic signature).

\section{Postlethwaite 1967}

Postlethwaite R, Watt JA, Hawley TG, Simpson I, Adam H. Features of molluscum contagiosum in the northeast of Scotland and in Fijian village settlements. Journal of Hygiene 1967;65(3):281-91. [PUBMED: 5233985]

\section{Quan 2000}

Quan LT, Orengo I. Surgical pearl: curetting with a punch. Journal of the American Academy of Dermatology 2000;43(5 Pt 1):854-5. [PUBMED: 11050593]

\section{Redmond 2004}

Redmond RM. Molluscum contagiosum is not always benign. BMJ 2004;329(7462):403. [PUBMED: 15310623]

\section{Relyveld 1988}

Relyveld J, Bergink AH, Nijhuis HGJ. Epidemiological notes. Leg ulcers, warts and dying circumstances [Epidemiologische notities. Ulcus cruris, wratten en sterfsituatie]. Huisarts en Wetenschap 1988;31:266-7.

\section{Rogers 1998}

Rogers M, Barnetson RSC. Diseases of the skin. In: Campbell AGM, McIntosh N, et al. editor(s). Forfar and Arneil's Textbook of Pediatrics. 5th Edition. New York: Churchill Livingstone, 1998:1633-5.

\section{Romiti 1999}

Romiti R, Ribeiro AP, Grinblat BM, Rivitti EA, Romiti N. Treatment of molluscum contagiosum with potassium hydroxide: a clinical approach in 35 children. Pediatric Dermatology 1999;16(3):228-31. [PUBMED: 10383783]

\section{Romiti 2000}

Romiti R, Ribeiro AP, Romiti N. Evaluation of the effectiveness of $5 \%$ potassium hydroxide for the treatment of molluscum contagiosum. Pediatric Dermatology 2000;17(6):495. [PUBMED: 11189099]

\section{Ross 2004}

Ross GL, Orchard DC. Combination topical treatment of molluscum contagiosum with cantharidin and imiquimod $5 \%$ in children: a case series of 16 patients. Australasian Journal of Dermatology 2004;45(2):100-2. [PUBMED: 15068455]

\section{Scheinfeld 2007}

Scheinfeld N. Treatment of molluscum contagiosum: a brief review and discussion of a case successfully treated with adapelene. Dermatology Online Journal 2007;13(3):15. [PUBMED: 18328209]

\section{Schmitt 2008}

Schmitt J, Diepgen TL. Molluscum contagiosum. In: Williams $\mathrm{H}$ Bigby M, Diepgen T, Herxheimer A, Naldi L, Rzany B editor(s). Evidence-based dermatology. 2nd Edition. Oxford: Blackwell, 2008:Web chapter, accessed 18 February 2009.

\section{Semkova 2014}

Semkova K, Palamaras I, Robles W. Hydrogen peroxide $1 \%$ cream under occlusion for treatment of molluscum contagiosum in an 8-month-old infant: an effective and safe treatment option. Clinical and Experimental Dermatology 2014;39(4):560-1. [PUBMED: 24825145]

\section{Sharma 1998}

Sharma AK. Cimetidine therapy for multiple molluscum contagiosum lesions. Dermatology 1998;197(2):194-5. [PUBMED: 9840981]

\section{Silverberg 2000}

Silverberg NB, Sidbury R, Mancini AJ. Childhood molluscum contagiosum: experience with cantharidin therapy in 300 patients. Journal of the American Academy of Dermatology 2000;43(3):503-7. [PUBMED: 10954663]

\section{Singh 1977}

Singh OP, Kanwar AJ. Griseofulvin therapy in molluscum contagiosum. Archives of Dermatology 1977;113(11):1615. [PUBMED: 931417]

\section{Skinner 2002}

Skinner RB. Treatment of molluscum contagiosum with imiquimod 5\% cream. Journal of the American Academy of Dermatology 2002;47(Suppl 4):221-4.

\section{Smith 2002}

Smith KJ, Skelton H. Molluscum contagiosum: recent advances in pathogenic mechanisms, and new therapies. American Jorunal of Clinical Dermatology 2002;3(8):535-45. [PUBMED: 12358555]

\section{Sterling 1998}

Sterling JC, Kurtz JB. Viral infections. In: Champion RH, Burton JL, Ebling FJG editor(s). Textbook of Dermatology. 6th Edition. Oxford: Blackwell, 1998:1005-8. 


\section{Stulberg 2003}

Stulberg DL, Hutchinson AG. Molluscum contagiosum and warts. American Family Physician 2003;67(6):1233-40. [PUBMED: 12674451]

\section{Sturt 1971}

Sturt RJ, Muller HK, Francis GD. Molluscum contagiosum in villages of the West Sepik district of New Guinea. Medical Journal of Australia 1971;2(15):751-4. [PUBMED: 5117269]

\section{Takemura 1983}

Takemura T, Ohkuma K, Nagai, H, Saito T. The natural history of molluscum contagiosum. Examination and treatment of dermatological diseases 1983;5(7):667-70.

\section{Teilla-Hamel 1996}

Teilla-Hamel D, Roux A, Loeb G. Pharmacokinetics and safety profile of topical podophyllotoxin ( $0.5 \%$ solution) on molluscum contagiosum in children. European Journal of Dermatology 1996;6:437-40.

\section{Torfs 1959}

Torfs M, Lambelin G. Considerations on Molluscum Contagiosum in the tropics [Considerations sur le Molluscum Contagiosum en milieu tropical]. Annales de la Societe Belge de Medecine Tropicale 1959;39:703-9.

\section{Toro 2000}

Toro JR, Wood LV, Patel NK, Turner ML. Topical cidofovir: a novel treatment for recalcitrant molluscum contagiosum in children infected with human immunodeficiency virus 1 . Archives of Dermatology 2000;136(8):983-5. [PUBMED: 10926733]

\section{Van der Linden 2005}

Van der Linden MW, van Suijlekom-Smit LWA, Schellevis FG, van der Wouden JC. [The child in general practice] Het kind in de huisartspraktijk. Rotterdam/Utrecht: Erasmus MC/NIVEL, 2005.

\section{Vasily 1978}

Vasily DB, Bhatia SG. Erythema annulare centrifugum and molluscum contagiosum. Archives of Dermatology 1978;114(12):1853. [PUBMED: 736595]

\section{Whitaker 1991}

Whitaker SB, Wiegand SE, Budnick SD. Intraoral molluscum contagiosum. Oral Surgery, Oral Medicine, Oral Pathology 1991;72(3):334-6. [PUBMED: 1923422]

\section{CHARACTERISTICS OF STUDIES}

Characteristics of included studies [ordered by study ID]

\section{Wieringa 2006}

Wieringa JW, Ketel AG, van Houten MA. Coma in a child after treatment with the 'magic salve' lidocaine-prilocaine cream [Coma bij een peuter na behandeling met de 'toverzalf' lidocaine-prilocainecreme]. Nederlands Tijdschrift voor Geneeskunde 2006;150(33):1805-7. [PUBMED: 16967588]

\section{Williams 1991}

Williams LR, Webster G. Warts and molluscum contagiosum. Clinical Dermatology 1991;9(1):87-93. [PUBMED: 1933729]

\section{Wishart 1903}

Wishart J. The local treatment of psoriasis and molluscum contagiosum. Lancet 1903;161(4154):1030-1.

\section{Yasher 1999}

Yasher SS, Shamiri B. Oral cimetidine treatment of molluscum contagiosum. Pediatric Dermatology 1999;16(6):493. [PUBMED: 10651572]

\section{Zabawski 1999}

Zabawski EJ Jr, Cockerell CJ. Topical cidofovir for molluscum contagiosum in children. Pediatric Dermatology 1999;16(5):414-5. [PUBMED: 10627225]

\section{References to other published versions of this review \\ Van der Wouden 2004}

van der Wouden JC, Gajadin S, Berger MY, Butler CC, Koning S, Menke J, et al. Interventions for molluscum contagiosum in children. Cochrane Database of Systematic Reviews 2004, Issue 2. [DOI: 10.1002/14651858.CD004767]

\section{Van der Wouden 2006}

van der Wouden JC, Koning S, van Suijlekom-Smit LWA, Berger M, Butler C, Menke J, et al. Interventions for cutaneous molluscum contagiosum. Cochrane Database of Systematic Reviews 2006, Issue 2. [DOI: 10.1002/14651858.CD004767]

\section{Van der Wouden 2009}

van der Wouden JC, van der Sande R, van Suijlekom-Smit LWA, Berger M, Butler CC, Koning S. Interventions for cutaneous molluscum contagiosum. Cochrane Database of Systematic Reviews 2009, Issue 4. [DOI: 10.1002/14651858.CD004767]

* Indicates the major publication for the study

Al-Mutairi 2010

\begin{tabular}{ll}
\hline Methods & Randomised controlled trial \\
\hline Participants & 74 children 2 to 12 years of age, hospital outpatient clinic in Kuwait \\
\hline Interventions & Imiquimod $5 \%$ for up to 16 weeks versus cryospray for up to 2 weeks \\
\hline
\end{tabular}


Al-Mutairi 2010 (Continued)

Outcomes Cure at 3, 6, 12, and 16 weeks; cosmetic outcome; adverse effects

Notes Funding: not mentioned

\section{Risk of bias}

\begin{tabular}{|c|c|c|}
\hline Bias & Authors' judgement & Support for judgement \\
\hline $\begin{array}{l}\text { Random sequence genera- } \\
\text { tion (selection bias) }\end{array}$ & Unclear risk & No details except 'randomly assigned' \\
\hline $\begin{array}{l}\text { Allocation concealment } \\
\text { (selection bias) }\end{array}$ & Unclear risk & No details \\
\hline $\begin{array}{l}\text { Blinding of participants } \\
\text { and personnel (perfor- } \\
\text { mance bias) } \\
\text { All outcomes }\end{array}$ & High risk & Probably not blinded: cream versus cryospray \\
\hline $\begin{array}{l}\text { Blinding of outcome as- } \\
\text { sessment (detection bias) } \\
\text { All outcomes }\end{array}$ & High risk & Probably not blinded: cream versus cryospray \\
\hline $\begin{array}{l}\text { Incomplete outcome data } \\
\text { (attrition bias) } \\
\text { Short-term outcomes (up } \\
\text { to } 3 \text { months) }\end{array}$ & Low risk & All participants had complete follow-up. \\
\hline $\begin{array}{l}\text { Incomplete outcome data } \\
\text { (attrition bias) } \\
\text { Medium- and long-term } \\
\text { outcomes (3-6 months and } \\
\text { longer) }\end{array}$ & Low risk & All participants had complete follow-up. \\
\hline $\begin{array}{l}\text { Selective reporting (re- } \\
\text { porting bias) }\end{array}$ & Unclear risk & Protocol not available \\
\hline Other bias & Unclear risk & $\begin{array}{l}\text { No baseline imbalance for gender, MC area, morphology, MC location, or base- } \\
\text { line lesion count, but no data on compliance }\end{array}$ \\
\hline
\end{tabular}

Antony 2001

\begin{tabular}{ll}
\hline Methods & Double-blind randomised placebo-controlled trial \\
\hline Participants & 38 patients (1 to 16 years; M/F: 18/20) were enrolled, Dept of Dermatology, UK. \\
\hline Interventions & $35 \mathrm{mg} / \mathrm{kg} /$ day cimetidine, given once daily as oral suspension versus a matching placebo for 3 months \\
\hline Outcomes & Complete clearance after 4 months of treatment. Reduction of lesions. Adverse events: not mentioned \\
\hline Notes & $50 \%$ dropout rate. Published abstract only. Funding: not mentioned \\
\hline Risk of bias & Authors' judgement Support for judgement \\
\hline Bias & Sus contagum \\
\hline \hline
\end{tabular}


Antony 2001 (Continued)

Random sequence genera- Unclear risk Quote: "Randomized". No details in abstract tion (selection bias)

Allocation concealment Unclear risk Method of concealment is not described in the abstract.
(selection bias)

(selection bias)

$\begin{array}{ll}\begin{array}{l}\text { Blinding of participants } \\ \text { and personnel (perfor- }\end{array} & \text { Quote: "Double-blind placebo-controlled"; "The dose of cimetidine was } 35 \\ \text { mance bias) } & \mathrm{mg} / \mathrm{kg}^{-1} / \mathrm{day}^{-1} \text { "; "The placebo group received a manufactured placebo". Prob- } \\ \text { All outcomes } & \text { ably done, placebo controlled, both suspensions }\end{array}$

All outcomes

\begin{tabular}{|c|c|c|}
\hline $\begin{array}{l}\text { Blinding of outcome as- } \\
\text { sessment (detection bias) } \\
\text { All outcomes }\end{array}$ & Low risk & $\begin{array}{l}\text { Quote: "Double-blind placebo-controlled"; "The dose of cimetidine was } 35 \\
\text { mg/kg-1/day-1"; "The placebo group received a manufactured placebo". Prob- } \\
\text { ably done, placebo controlled, both suspensions }\end{array}$ \\
\hline
\end{tabular}

\begin{tabular}{|c|c|c|}
\hline $\begin{array}{l}\text { Incomplete outcome data } \\
\text { (attrition bias) } \\
\text { Short-term outcomes (up } \\
\text { to } 3 \text { months) }\end{array}$ & Unclear risk & Not reported in the abstract \\
\hline $\begin{array}{l}\text { Incomplete outcome data } \\
\text { (attrition bias) } \\
\text { Medium- and long-term } \\
\text { outcomes (3-6 months and } \\
\text { longer) }\end{array}$ & High risk & $\begin{array}{l}4 \text { months: } 19 / 35 \text { completed the treatment course. Quote: "The number of pa- } \\
\text { tients who received placebo or cimetidine was similar in the groups that did } \\
\text { not attend or withdrew." > 30\% withdrawals }\end{array}$ \\
\hline $\begin{array}{l}\text { Selective reporting (re- } \\
\text { porting bias) }\end{array}$ & Unclear risk & Unclear \\
\hline Other bias & Unclear risk & $\begin{array}{l}\text { Quote: "The mean age and sex of the patients and incidence of atopic disease } \\
\text { in each treatment group was similar." No compliance data }\end{array}$ \\
\hline
\end{tabular}

\section{Bazza 2007}

\begin{tabular}{|c|c|c|}
\hline Methods & \multicolumn{2}{|c|}{ Randomised controlled trial. Body sides were randomised left-right. } \\
\hline Participants & \multicolumn{2}{|c|}{30 children ( 2 to 12 years of age; M/F: 18/12) were recruited, Dept of Dermatology, UK. } \\
\hline Interventions & \multicolumn{2}{|c|}{ Sterile normal $0.9 \%$ saline versus $5 \%$ potassium hydroxide for 3 weeks } \\
\hline Outcomes & \multicolumn{2}{|c|}{ Complete clearance of lesions and side effects after 12 weeks } \\
\hline Notes & \multicolumn{2}{|c|}{ Unpublished, year of study unclear. Unpublished paper obtained in 2007. Funding: not mentioned } \\
\hline \multicolumn{3}{|l|}{ Risk of bias } \\
\hline Bias & Authors' judgement & Support for judgement \\
\hline $\begin{array}{l}\text { Random sequence genera- } \\
\text { tion (selection bias) }\end{array}$ & Unclear risk & $\begin{array}{l}\text { Quote: "Where treatment with } 0.9 \% \mathrm{NS} \text { and } 5 \% \mathrm{KOH} \text { solution was randomised } \\
\text { to right or left side of body". Insufficient information }\end{array}$ \\
\hline $\begin{array}{l}\text { Allocation concealment } \\
\text { (selection bias) }\end{array}$ & Unclear risk & $\begin{array}{l}\text { Quote: "Where treatment with } 0.9 \% \mathrm{NS} \text { and } 5 \% \mathrm{KOH} \text { solution was randomised } \\
\text { to right or left side of body". Insufficient information }\end{array}$ \\
\hline
\end{tabular}




\section{Bazza 2007 (Continued)}

Blinding of participants and personnel (performance bias)

All outcomes
Low risk Quote: "30 patients were recruited in this double-blind study". "All subjects were given seven bottles clearly labelled $R$ and seven bottles labelled $L$, for use on the right and left side of the body respectively (patient and investigator did not know which is active site)"

\title{
Blinding of outcome as- Low risk sessment (detection bias)
}

Quote: "30 patients were recruited in this double-blind study". "All subjects were given seven bottles clearly labelled $R$ and seven bottles labelled $L$, for use All outcomes on the right and left side of the body respectively (patient and investigator did not know which is active site)"

\begin{tabular}{|c|c|c|}
\hline $\begin{array}{l}\text { Incomplete outcome data } \\
\text { (attrition bias) }\end{array}$ & High risk & $\begin{array}{l}12 \text { weeks: } 10 / 30 \text { did not complete study, } 2 \text { withdrew due to severe stinging } \\
\text { from } \mathrm{KOH} \text {, and } 8 \text { children were lost to follow-up. }>30 \% \text { dropouts }\end{array}$ \\
\hline
\end{tabular}

Short-term outcomes (up

to 3 months)

\author{
Incomplete outcome data \\ (attrition bias) \\ Medium- and long-term \\ outcomes (3-6 months and \\ longer)
}

\begin{tabular}{lll}
\hline $\begin{array}{l}\text { Selective reporting (re- } \\
\text { porting bias) }\end{array}$ & Unclear risk & Unclear \\
\hline Other bias & Unclear risk & No baseline comparison. No compliance data \\
\hline
\end{tabular}

Burke 2004

\begin{tabular}{ll}
\hline Methods & Randomised controlled trial \\
\hline Participants & 31 children, mean age 4.6 years. Sex not reported. USA, outpatient clinic \\
\hline Interventions & $10 \%$ lemon myrtle oil or vehicle (olive oil) for 3 weeks \\
\hline Outcomes & Complete clearance or $>90 \%$ reduction in number of lesions after 3 weeks \\
\hline Notes & $\begin{array}{l}\text { Funding: Center for Biomedical Research, a commercial institute involved in drug research and sale. } \\
\text { Partner of Naturopathix (ZymaDerm for molluscum) }\end{array}$ \\
\hline
\end{tabular}

\section{Risk of bias}

Bias Authors' judgement Support for judgement

\begin{tabular}{lll}
\hline $\begin{array}{l}\text { Random sequence genera- } \\
\text { tion (selection bias) }\end{array}$ & Low risk & $\begin{array}{l}\text { Quote: "Children were randomised to active treatment or vehicle (virgin olive } \\
\text { oil) by blindly choosing a token numbered from } 1 \text { to } 100 . \text { Odd numbers were } \\
\text { assigned to active treatment even numbers to vehicle" }\end{array}$ \\
\hline $\begin{array}{l}\text { Allocation concealment } \\
\text { (selection bias) }\end{array}$ & Low risk & $\begin{array}{l}\text { Quote: "Children were randomised to active treatment or vehicle (virgin olive } \\
\text { oil) by blindly choosing a token numbered from } 1 \text { to } 100 . " \text { "Parents and physi- } \\
\text { cians were blinded to treatment protocol. A treatment key was held by a par- } \\
\text { ticipating pharmacist (no patient contact) until study completion" }\end{array}$
\end{tabular}

\begin{tabular}{|c|c|c|}
\hline $\begin{array}{l}\text { Blinding of participants } \\
\text { and personnel (perfor- } \\
\text { mance bias) }\end{array}$ & Low risk & $\begin{array}{l}\text { Quote: "Parents and physicians were blinded to treatment protocol. A treat- } \\
\text { ment key was held by a participating pharmacist (no patient contact) until } \\
\text { study completion." "A mild synthetic lemon fragrance not containing citral }\end{array}$ \\
\hline
\end{tabular}


Burke 2004 (Continued)

was added to scent the control olive oil preparation. This fragrance by itself had no therapeutic effect." Vehicle controlled.

\section{Blinding of outcome as- Low risk} sessment (detection bias)

All outcomes

Quote: "Parents and physicians were blinded to treatment protocol. A treatment key was held by a participating pharmacist (no patient contact) until study completion." "A mild synthetic lemon fragrance not containing citral was added to scent the control olive oil preparation. This fragrance by itself had no therapeutic effect." Vehicle controlled.

\begin{tabular}{ll}
\hline $\begin{array}{l}\text { Incomplete outcome data } \\
\text { (attrition bias) }\end{array}$ & Low risk \\
Short-term outcomes (up & 21 days: $4 / 31$ withdrew: $1 / 16$ in lemon myrtle oil group lost to follow-up; $3 / 15$ \\
missing in vehicle group, withdrew because of worsening of the molluscum.
\end{tabular}
to 3 months)

\begin{tabular}{lll}
\hline $\begin{array}{l}\text { Incomplete outcome data } \\
\text { (attrition bias) } \\
\text { Medium- and long-term } \\
\text { outcomes (3-6 months and } \\
\text { longer) }\end{array}$ & Unclear risk & The study did not address medium- and long-term outcomes. \\
\hline $\begin{array}{l}\text { Selective reporting (re- } \\
\text { porting bias) }\end{array}$ & Unclear risk & Unclear \\
\hline $\begin{array}{l}\text { Other bias } \\
\text { Unclear risk }\end{array}$ & $\begin{array}{l}\text { The mean number of lesions at enrolment did not differ between treatment } \\
\text { groups. No sex or age comparison between groups. No compliance data }\end{array}$
\end{tabular}

\section{Chathra 2015}

\begin{tabular}{ll}
\hline Methods & Randomised trial \\
\hline Participants & Children 1 to 18 years with a minimum of 3 molluscum lesions, target sample size 40, Karnataka, India \\
\hline Interventions & $\begin{array}{l}\text { Imiquimod } 5 \% \text { cream application alternate nights versus } 10 \% \text { potassium hydroxide solution applied al- } \\
\text { ternate nights for } 12 \text { weeks }\end{array}$ \\
\hline Outcomes & Complete clearance, time points 4,8, and 12 weeks \\
\hline Notes & Funding: this study reported that they had no support.
\end{tabular}

\section{Risk of bias}

\begin{tabular}{lll}
\hline Bias & Authors' judgement & Support for judgement \\
\hline $\begin{array}{l}\text { Random sequence genera- } \\
\text { tion (selection bias) }\end{array}$ & Unclear risk & "The lottery method"; no details \\
\hline $\begin{array}{l}\text { Allocation concealment } \\
\text { (selection bias) }\end{array}$ & Unclear risk & No details \\
\hline $\begin{array}{l}\text { Blinding of participants } \\
\text { and personnel (perfor- } \\
\text { mance bias) } \\
\begin{array}{l}\text { All outcomes } \\
\text { Blinding of outcome as- } \\
\text { sessment (detection bias) }\end{array}\end{array}$ & High risk & Different instructions, therefore not blinded \\
\hline
\end{tabular}


Chathra 2015 (Continued)

All outcomes

Incomplete outcome data Low risk No loss to follow-up
(attrition bias)
Short-term outcomes (up
to 3 months)

\begin{tabular}{|c|c|c|}
\hline $\begin{array}{l}\text { Incomplete outcome data } \\
\text { (attrition bias) } \\
\text { Medium- and long-term } \\
\text { outcomes (3-6 months and } \\
\text { longer) }\end{array}$ & Unclear risk & No medium- and long-term outcomes \\
\hline $\begin{array}{l}\text { Selective reporting (re- } \\
\text { porting bias) }\end{array}$ & Unclear risk & No protocol available \\
\hline Other bias & Unclear risk & $\begin{array}{l}\text { No baseline imbalance in terms of age, gender, and number of lesions. No } \\
\text { compliance data }\end{array}$ \\
\hline
\end{tabular}

Coloe Dosal 2014

\begin{tabular}{ll}
\hline Methods & Randomised controlled trial \\
\hline Participants & $\begin{array}{l}32 \text { children, } 5 \text { to } 10 \text { years of age, recruited in local paediatricians' offices, university clinics and through } \\
\text { mass emails to university students and staff, North Carolina, USA }\end{array}$ \\
\hline Interventions & Cantharidin collodion $0.7 \%$ versus vehicle collodion for approximately 8 weeks \\
\hline Outcomes & Complete clearance, lesion counts, adverse effects, approximately 8 weeks after start of treatment \\
\hline Notes & Funding: Doris Duke Charitable Foundation
\end{tabular}

\section{Risk of bias}

\begin{tabular}{|c|c|c|}
\hline Bias & Authors' judgement & Support for judgement \\
\hline $\begin{array}{l}\text { Random sequence genera- } \\
\text { tion (selection bias) }\end{array}$ & Low risk & $\begin{array}{l}\text { "Randomization schedule was prepared before first recruitment using permut- } \\
\text { ed blocks of size 2" }\end{array}$ \\
\hline $\begin{array}{l}\text { Allocation concealment } \\
\text { (selection bias) }\end{array}$ & Low risk & $\begin{array}{l}\text { After eligibility was assessed, study personnel "assigned the next unique sub- } \\
\text { ject identification number and dispensed the appropriate drug" }\end{array}$ \\
\hline $\begin{array}{l}\text { Blinding of participants } \\
\text { and personnel (perfor- } \\
\text { mance bias) } \\
\text { All outcomes }\end{array}$ & Low risk & $\begin{array}{l}\text { "Patients, parents and investigators were blinded to treatment assignment" } \\
\text { and "placebo was identical in texture and smell" }\end{array}$ \\
\hline $\begin{array}{l}\text { Blinding of outcome as- } \\
\text { sessment (detection bias) } \\
\text { All outcomes }\end{array}$ & Low risk & $\begin{array}{l}\text { "Patients, parents and investigators were blinded to treatment assignment" } \\
\text { and "placebo was identical in texture and smell" }\end{array}$ \\
\hline $\begin{array}{l}\text { Incomplete outcome data } \\
\text { (attrition bias) } \\
\text { Short-term outcomes (up } \\
\text { to } 3 \text { months) }\end{array}$ & Low risk & $\begin{array}{l}2 \text { participants dropped out immediately after randomisation because they did } \\
\text { not meet all eligibility criteria }(<20 \%) \text {. }\end{array}$ \\
\hline
\end{tabular}


Coloe Dosal 2014 (Continued)

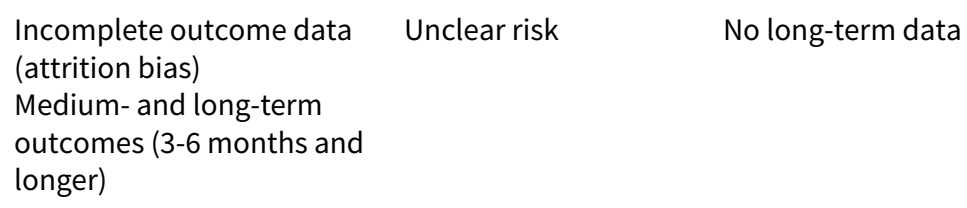

Other bias Unclear risk Imbalance in dry skin. Allocation bias was due to dropout.

\section{Eichenfield 2005}

\begin{tabular}{ll}
\hline Methods & Randomised controlled trial \\
\hline Participants & $\begin{array}{l}323 \text { children, } 2 \text { to } 12 \text { years of age, with molluscum contagiosum in } 19 \text { outpatient clinics in the USA were } \\
\text { randomised. }\end{array}$ \\
\hline Interventions & Imiquimod cream $5 \%$ vs vehicle cream 3 times weekly for 16 weeks \\
\hline Outcomes & $\begin{array}{l}\text { Lesion clearance, lesion counts, time to complete clearance, side effects after } 4,8,12,16,18, \text { and } 28 \\
\text { weeks }\end{array}$ \\
\hline Notes & Funding by pharmaceutical company (3M), unpublished \\
\hline
\end{tabular}

\section{Risk of bias}

\begin{tabular}{|c|c|c|}
\hline Bias & Authors' judgement & Support for judgement \\
\hline $\begin{array}{l}\text { Random sequence genera- } \\
\text { tion (selection bias) }\end{array}$ & Low risk & $\begin{array}{l}\text { "Subjects were randomly assigned to a treatment arm in blocks of } 6 \text { accord- } \\
\text { ing to a computer-generated randomizations schedule. Randomization was } \\
\text { 2:1 (active:vehicle) for a planned number of } 300 \text { subjects to be randomised in- } \\
\text { to the study" (p.40) }\end{array}$ \\
\hline $\begin{array}{l}\text { Allocation concealment } \\
\text { (selection bias) }\end{array}$ & Low risk & $\begin{array}{l}\text { "The treatment assignments were concealed from the subjects, investiga- } \\
\text { tors and study staff, and the } 3 \mathrm{M} \text { clinical research team. The clinical packaging } \\
\text { group at } 3 \mathrm{M} \text { Pharmaceuticals held the master code for the treatment random- } \\
\text { izations schedule, and supplied the investigators with each subject's treat- } \\
\text { ment assignment as a hidden (tear-off) panel on the study cream label, which } \\
\text { was affixed to the blinded Drug Label page" (p.43) }\end{array}$ \\
\hline $\begin{array}{l}\text { Blinding of participants } \\
\text { and personnel (perfor- } \\
\text { mance bias) } \\
\text { All outcomes }\end{array}$ & Low risk & See allocation concealment. \\
\hline $\begin{array}{l}\text { Blinding of outcome as- } \\
\text { sessment (detection bias) } \\
\text { All outcomes }\end{array}$ & Low risk & See allocation concealment. \\
\hline $\begin{array}{l}\text { Incomplete outcome data } \\
\text { (attrition bias) } \\
\text { Short-term outcomes (up } \\
\text { to } 3 \text { months) }\end{array}$ & Unclear risk & $\begin{array}{l}\text { Unclear when participants dropped out, so impossible to distinguish short- } \\
\text { term from long-term. Primary analysis by intention-to-treat }\end{array}$ \\
\hline
\end{tabular}


Eichenfield 2005 (Continued)

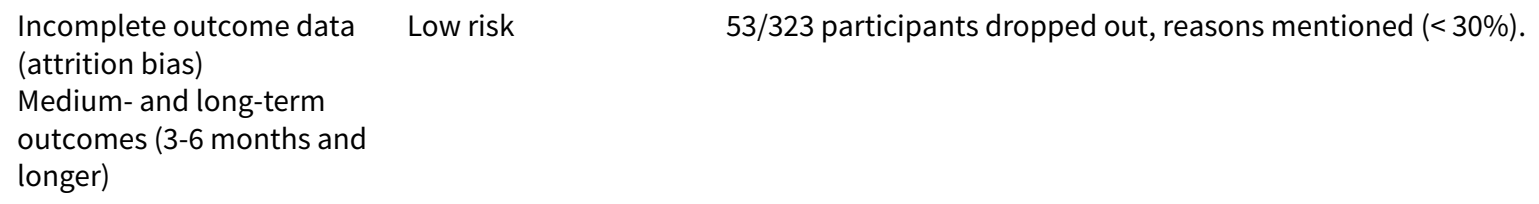

\begin{tabular}{lll}
\hline $\begin{array}{l}\text { Selective reporting (re- } \\
\text { porting bias) }\end{array}$ & Low risk & All outcomes seem to have been reported. \\
\hline Other bias & Low risk & $\begin{array}{l}\text { No baseline imbalance, compliance data available, primary analysis by inten- } \\
\text { tion-to-treat }\end{array}$ \\
\hline
\end{tabular}

Handjani 2014

\begin{tabular}{ll}
\hline Methods & Open randomised trial \\
\hline Participants & 30 people with molluscum contagiosum in Iran \\
\hline Interventions & $10 \%$ potassium hydroxide solution versus cryotherapy \\
\hline Outcomes & Lesion response and side effects 4 weeks after start of treatment \\
\hline Notes & Funding: not mentioned
\end{tabular}

\section{Risk of bias}

\begin{tabular}{|c|c|c|}
\hline Bias & Authors' judgement & Support for judgement \\
\hline $\begin{array}{l}\text { Random sequence genera- } \\
\text { tion (selection bias) }\end{array}$ & Unclear risk & "the simple randomization method"; no details \\
\hline $\begin{array}{l}\text { Allocation concealment } \\
\text { (selection bias) }\end{array}$ & Unclear risk & No details \\
\hline $\begin{array}{l}\text { Blinding of participants } \\
\text { and personnel (perfor- } \\
\text { mance bias) } \\
\text { All outcomes }\end{array}$ & High risk & Different administration, so could not be blinded \\
\hline $\begin{array}{l}\text { Blinding of outcome as- } \\
\text { sessment (detection bias) } \\
\text { All outcomes }\end{array}$ & High risk & Different administration, so could not be blinded \\
\hline $\begin{array}{l}\text { Incomplete outcome data } \\
\text { (attrition bias) } \\
\text { Short-term outcomes (up } \\
\text { to } 3 \text { months) }\end{array}$ & Low risk & No loss to follow-up \\
\hline $\begin{array}{l}\text { Incomplete outcome data } \\
\text { (attrition bias) } \\
\text { Medium- and long-term } \\
\text { outcomes (3-6 months and } \\
\text { longer) }\end{array}$ & Unclear risk & Not applicable, no medium- and long-term outcomes \\
\hline
\end{tabular}


Handjani 2014 (Continued)

Selective reporting (re- $\quad$ Unclear risk $\quad$ No protocol available
porting bias)

Other bias Unclear risk No baseline comparison; no compliance data

Hanna 2006

\begin{tabular}{ll}
\hline Methods & Randomised controlled trial \\
\hline Participants & $\begin{array}{l}124 \text { children, } 1 \text { to } 16 \text { years of age, dermatology clinic, Montreal, Canada } \\
\text { M/F: } 57 / 67\end{array}$ \\
\hline Interventions & $\begin{array}{l}4 \text { arms: curettage, topical cantharidin } 0.7 \% \text {, topical salicylic acid } 16.7 \%+\text { lactic acid } 16.7 \%, \text { topical im- } \\
\text { iquimod cream } 5 \%\end{array}$ \\
\hline Outcomes & $\begin{array}{l}\text { Number of visits required. Intervals between study visits not reported, so outcome data not suitable for } \\
\text { inclusion. }\end{array}$ \\
\hline Notes & $\begin{array}{l}\text { Total number of participants unclear. Percentage of group } 3 \text { in Table } 1 \text { does not correspond to number } \\
\text { mentioned in text. }\end{array}$ \\
Funding: 3 pharmaceutical companies provided treatments for free.
\end{tabular}

Risk of bias

\begin{tabular}{|c|c|c|}
\hline Bias & Authors' judgement & Support for judgement \\
\hline $\begin{array}{l}\text { Random sequence genera- } \\
\text { tion (selection bias) }\end{array}$ & Low risk & $\begin{array}{l}\text { Quote: "The randomizations list was generated by specialized computer soft- } \\
\text { ware (PC-PLAN, Dalal, 1996)" }\end{array}$ \\
\hline $\begin{array}{l}\text { Allocation concealment } \\
\text { (selection bias) }\end{array}$ & Unclear risk & $\begin{array}{l}\text { Quote: "The randomizations list was generated by specialized computer soft- } \\
\text { ware (PC-PLAN, Dalal, 1996)." Insufficient information }\end{array}$ \\
\hline $\begin{array}{l}\text { Blinding of participants } \\
\text { and personnel (perfor- } \\
\text { mance bias) } \\
\text { All outcomes }\end{array}$ & High risk & Quote: "This is not a double-blind study." Physical versus topical treatment \\
\hline $\begin{array}{l}\text { Blinding of outcome as- } \\
\text { sessment (detection bias) } \\
\text { All outcomes }\end{array}$ & High risk & Quote: "This is not a double-blind study." Physical versus topical treatment \\
\hline $\begin{array}{l}\text { Incomplete outcome data } \\
\text { (attrition bias) } \\
\text { Short-term outcomes (up } \\
\text { to } 3 \text { months) }\end{array}$ & Unclear risk & Not reported \\
\hline $\begin{array}{l}\text { Incomplete outcome data } \\
\text { (attrition bias) } \\
\text { Medium- and long-term } \\
\text { outcomes (3-6 months and } \\
\text { longer) }\end{array}$ & Unclear risk & Not reported \\
\hline $\begin{array}{l}\text { Selective reporting (re- } \\
\text { porting bias) }\end{array}$ & Unclear risk & Unclear \\
\hline
\end{tabular}


Hanna 2006 (Continued)
Other bias
Unclear risk
No baseline comparison. No compliance data

Leslie 2005

\begin{tabular}{ll}
\hline Methods & Randomised controlled trial \\
\hline Participants & $\begin{array}{l}114 \text { children, } 1 \text { to } 15 \text { years of age, sex not reported, UK, outpatient departments of teaching hospital } \\
\text { and district general hospital }\end{array}$ \\
\hline Interventions & $\begin{array}{l}\text { Topical salicylic acid } 12 \%, \text { or phenol } 10 \%+70 \% \text { alcohol, or } 70 \% \text { alcohol at monthly visits for a maxi- } \\
\text { mum of } 6 \text { months }\end{array}$ \\
\hline Outcomes & Complete clearance of lesions after 6 months \\
\hline Notes & Funding: pharmaceutical company provided medication
\end{tabular}

\section{Risk of bias}

\begin{tabular}{|c|c|c|}
\hline Bias & Authors' judgement & Support for judgement \\
\hline $\begin{array}{l}\text { Random sequence genera- } \\
\text { tion (selection bias) }\end{array}$ & Low risk & $\begin{array}{l}\text { Quote: "The participants were randomised according to a random number ta- } \\
\text { ble" }\end{array}$ \\
\hline $\begin{array}{l}\text { Allocation concealment } \\
\text { (selection bias) }\end{array}$ & High risk & Quote: "The investigators were not blinded to randomizations" \\
\hline $\begin{array}{l}\text { Blinding of participants } \\
\text { and personnel (perfor- } \\
\text { mance bias) } \\
\text { All outcomes }\end{array}$ & High risk & $\begin{array}{l}\text { Quote: "The patients in the salicylic acid groups were aware of their treat- } \\
\text { ments. The other two groups treated with vehicle or phenol were single-blind- } \\
\text { ed, as the patients/parents were unaware of which treatment they received." } \\
\text { "The vehicle and diluted phenol were prepared by the hospital pharmacy and } \\
\text { labelled with a letter." "The investigators were not blinded for the randomiza- } \\
\text { tion" }\end{array}$ \\
\hline
\end{tabular}

$\begin{array}{ll}\begin{array}{l}\text { Blinding of outcome as- } \\ \text { sessment (detection bias) }\end{array} & \text { High risk } \\ \begin{array}{ll}\text { All outcomes } & \text { Quote: "The patients in the salicylic acid groups were aware of their treat- } \\ \text { ments. The other two groups treated with vehicle or phenol were single-blind- } \\ \text { ed, as the patients/parents were unaware of which treatment they received." } \\ \text { "The vehicle and diluted phenol were prepared by the hospital pharmacy and } \\ \text { labelled with a letter." "The investigators were not blinded for the randomiza- } \\ \text { tion" }\end{array}\end{array}$

Incomplete outcome data Unclear risk No short-term outcomes reported.

(attrition bias)

Short-term outcomes (up

to 3 months)

\begin{tabular}{lll}
\hline $\begin{array}{l}\text { Incomplete outcome data } \\
\text { (attrition bias) }\end{array}$ & High risk & $\begin{array}{l}\text { Up to } 6 \text { months: } 31 / 114 \text { lost to follow-up: 13/37 in salicylic acid arm, } 9 / 41 \text { in di- } \\
\text { lute phenol arm, } 9 / 36 \text { in alcohol arm. }>30 \% \text { dropouts }\end{array}$ \\
$\begin{array}{l}\text { Medium- and long-term } \\
\text { outcomes (3-6 months and } \\
\text { longer) }\end{array}$ & \\
\hline $\begin{array}{l}\text { Selective reporting (re- } \\
\text { porting bias) }\end{array}$ & Unclear risk & Unclear \\
\hline
\end{tabular}


Leslie 2005 (Continued)

$\begin{array}{ll}\text { Other bias } & \text { Unclear risk } \\ & \text { so Table I, Baseline characteristics. No compliance data }\end{array}$

Machado 2010

\begin{tabular}{ll}
\hline Methods & Randomised controlled trial \\
\hline Participants & 50 children, 3 to 15 years of age, recruited in a hospital outpatient clinic in Brazil \\
\hline Interventions & $\begin{array}{l}\text { (1) potassium hydroxide } 10 \% \text { in aqueous solution; (2) } 14 \% \text { salicylic acid + } 14 \% \text { lactic acid in collodion; } \\
\text { both for } 3 \text { months or (3) curettage once }\end{array}$ \\
\hline Outcomes & Cure, adverse effects 90 days after start of treatment \\
\hline Notes & $\begin{array}{l}2 \text { groups applied medication at home; treatment duration was not reported for these groups. These } \\
\text { participants were seen every } 15 \text { days until day } 90 \text { after start of treatment. The third group underwent } \\
\text { curettage (once). These participants were seen day } 7 \text { and } 90 \text { after treatment. Outcomes were reported } \\
\text { at } 90 \text { days, but as we do not know how long topical treatments were applied and assuming that parents } \\
\text { were instructed to stop treatment when lesions had resolved, it is hard to say whether these are short- } \\
\text { or long-term outcomes (apart from the curettage group). } \\
\text { Funding: } 2 \text { pharmaceutical companies provided medication. }\end{array}$ \\
\hline
\end{tabular}

\section{Risk of bias}

\begin{tabular}{|c|c|c|}
\hline Bias & Authors' judgement & Support for judgement \\
\hline $\begin{array}{l}\text { Random sequence genera- } \\
\text { tion (selection bias) }\end{array}$ & Unclear risk & $\begin{array}{l}\text { "Patients were allocated randomly into three study groups"; insufficient infor- } \\
\text { mation }\end{array}$ \\
\hline $\begin{array}{l}\text { Allocation concealment } \\
\text { (selection bias) }\end{array}$ & Unclear risk & No details \\
\hline $\begin{array}{l}\text { Blinding of participants } \\
\text { and personnel (perfor- } \\
\text { mance bias) } \\
\text { All outcomes }\end{array}$ & High risk & Different treatments: topical treatment versus curettage \\
\hline $\begin{array}{l}\text { Blinding of outcome as- } \\
\text { sessment (detection bias) } \\
\text { All outcomes }\end{array}$ & High risk & $\begin{array}{l}\text { Different treatments: topical treatment versus curettage. Also, follow-up mo- } \\
\text { ments differed between treatment groups (topical: every } 15 \text { days for } 90 \text { days; } \\
\text { curettage: days } 7 \text { and } 90 \text { after the procedure) }\end{array}$ \\
\hline $\begin{array}{l}\text { Incomplete outcome data } \\
\text { (attrition bias) } \\
\text { Short-term outcomes (up } \\
\text { to } 3 \text { months) }\end{array}$ & Unclear risk & $\begin{array}{l}\text { Proportions in table and text show that these were not based on number of } \\
\text { participants randomised, so there must have been loss to follow-up; magni- } \\
\text { tude unclear. }\end{array}$ \\
\hline $\begin{array}{l}\text { Incomplete outcome data } \\
\text { (attrition bias) } \\
\text { Medium- and long-term } \\
\text { outcomes ( } 3-6 \text { months and } \\
\text { longer) }\end{array}$ & Unclear risk & No medium- or long-term follow-up \\
\hline $\begin{array}{l}\text { Selective reporting (re- } \\
\text { porting bias) }\end{array}$ & Unclear risk & No protocol \\
\hline
\end{tabular}


Machado 2010 (Continued)

Other bias Unclear risk No baseline comparison. Imbalance in treatment adherence (not statistically significant)

Manchanda 1997b

Methods Double-blind randomised controlled trial, addressing various types of warts $(n=124)$, including mollus-
cum contagiosum $(n=20)$

\begin{tabular}{ll} 
Participants & $\begin{array}{l}\text { 14 molluscum patients (sex distribution unknown) randomised to the treatment arm, } 6 \text { patients were } \\
\text { randomised to receive plain sugar globules as a placebo (personal communication Dr Manchanda). } 10 \\
\text { participants were aged below } 10 \text { years; } 7 \text { from } 10 \text { to } 20 \text { years; and } 3 \text { from } 21 \text { to } 30 \text { years (personal com- } \\
\text { munication with Dr Manchanda). India, Homoeopathic Medical College \& Hospital, New Delhi }\end{array}$ \\
\hline Interventions & $\begin{array}{l}\text { Different potencies of homeopathic drug calcarea carbonica daily for } 15 \text { days ( } \mathrm{n}=14) \text { versus sugar } \\
\text { globules (placebo). Unclear which participants received what potency }\end{array}$ \\
\hline Outcomes & Improvement (not clear after what period) \\
\hline Notes & $\begin{array}{l}\text { Paper reports on (1) cross-over study and (2) parallel study. We excluded the cross-over study because } \\
1 \text { arm had fewer than } 5 \text { participants. } \\
\text { Funding: not mentioned }\end{array}$
\end{tabular}

\section{Risk of bias}

\begin{tabular}{lll}
\hline Bias & Authors' judgement & Support for judgement \\
\hline $\begin{array}{l}\text { Random sequence genera- } \\
\text { tion (selection bias) }\end{array}$ & Unclear risk & $\begin{array}{l}\text { Quote: "In this research design, each case was initially given a drug code in } 30 \\
\text { potency which could be either active drug or placebo." Randomisation not } \\
\text { mentioned in paper, "sequence was generated manually" (personal communi- } \\
\text { cation) }\end{array}$ \\
\hline $\begin{array}{l}\text { Allocation concealment } \\
\text { (selection bias) }\end{array}$ & Unclear risk & $\begin{array}{l}\text { Quote: "In this research design, each case was initially given a drug code in } 30 \\
\text { potency which could be either active drug or placebo." "Therefore it was found } \\
\text { that after decoding method of concealment is not described" }\end{array}$ \\
\hline $\begin{array}{l}\text { Blinding of participants } \\
\text { and personnel (perfor- } \\
\text { mance bias) }\end{array}$ & Low risk & $\begin{array}{l}\text { Quote: "Two types of placebo controlled double-blind clinical trials were un- } \\
\text { dertaken." "The subjects were given both drug and placebo." Quote (person- } \\
\text { al communication): "The identity of the drugs was kept secret in a sealed cov- } \\
\text { er which was opened only at the time un-blinding the experiment." "The plain } \\
\text { sugar globules looks like homoeopathic drug Calcerea carbonica was used as } \\
\text { placebo." }\end{array}$ \\
\hline $\begin{array}{l}\text { Blinding of outcome as- } \\
\text { sessment (detection bias) } \\
\text { All outcomes }\end{array}$ & Low risk & $\begin{array}{l}\text { Quote: "Two types of placebo controlled double-blind clinical trials were un- } \\
\text { dertaken." "The subjects were given both drug and placebo." Quote (person- } \\
\text { al communication): "The identity of the drugs was kept secret in a sealed cov- } \\
\text { er which was opened only at the time un-blinding the experiment." "The plain } \\
\text { sugar globules looks like homoeopathic drug Calcerea carbonica was used as } \\
\text { placebo." }\end{array}$
\end{tabular}

Incomplete outcome data Low risk

15 days: 20/124 dropouts, unclear what skin disease and group assignment

(attrition bias)

Short-term outcomes (up

to 3 months) 
Manchanda 1997b (Continued)
Incomplete outcome data
Unclear risk
No long-term outcome
(attrition bias)

Medium- and long-term

outcomes (3-6 months and

longer)

\begin{tabular}{lll}
\hline $\begin{array}{l}\text { Selective reporting (re- } \\
\text { porting bias) }\end{array}$ & Unclear risk & Unclear \\
\hline Other bias & Unclear risk & No baseline comparison. No compliance data \\
\hline
\end{tabular}

Markum 2012

\begin{tabular}{ll}
\hline Methods & Randomised controlled trial \\
\hline Participants & $\begin{array}{l}53 \text { children (aged } 9 \text { months to } 15 \text { years according to trial register), recruited in outpatient clinic in Ida- } \\
\text { ho, USA }\end{array}$ \\
\hline Interventions & $(1)$ iodine; (2) tea tree oil (Melaleuca alternifolia); (3) tea tree oil + iodine for 30 days \\
\hline Outcomes & Cure or reduction in the number of lesions $>90 \%$, adverse effects, 30 days after start of treatment \\
\hline Notes & $\begin{array}{l}\text { Funding: Center for Biomedical Research, a commercial institute involved in drug research and sale. } \\
\text { Partner of Naturopathix (ZymaDerm for molluscum) }\end{array}$ \\
\hline
\end{tabular}

\section{Risk of bias}

\begin{tabular}{lll}
\hline Bias & Authors' judgement & Support for judgement \\
\hline $\begin{array}{ll}\text { Random sequence genera- } \\
\text { tion (selection bias) }\end{array}$ & Low risk & $\begin{array}{l}\text { According to trial register: "Subject or subject's parent blindly chose a num- } \\
\text { bered token from an opaque container containing tokens numbered 1-99. } \\
\text { Numbers 1-33 assigned to iodine treatment, numbers 34-66 assigned to tea } \\
\text { tree oil treatment, numbers 67-99 assigned to tea tree oil + iodine treatment" } \\
\text { and "Randomization by sealed container" }\end{array}$ \\
& & \\
\hline
\end{tabular}

\begin{tabular}{|c|c|c|}
\hline $\begin{array}{l}\text { Allocation concealment } \\
\text { (selection bias) }\end{array}$ & Low risk & $\begin{array}{l}\text { According to trial register: "Subject or subject's parent blindly chose a num- } \\
\text { bered token from an opaque container containing tokens numbered 1-99. } \\
\text { Numbers 1-33 assigned to iodine treatment, numbers } 34-66 \text { assigned to tea } \\
\text { tree oil treatment, numbers } 67-99 \text { assigned to tea tree oil + iodine treatment" }\end{array}$ \\
\hline
\end{tabular}

\begin{tabular}{|c|c|c|}
\hline $\begin{array}{l}\text { Blinding of participants } \\
\text { and personnel (perfor- } \\
\text { mance bias) }\end{array}$ & Low risk & $\begin{array}{l}\text { Quote: "Patients and physicians were blinded to treatment protocol." "A mild } \\
\text { synthetic lemon fragrance not containing citral was added to scent the iodine } \\
\text { olive oil preparation." }\end{array}$ \\
\hline
\end{tabular}

All outcomes

\begin{tabular}{|c|c|c|}
\hline $\begin{array}{l}\text { Blinding of outcome as- } \\
\text { sessment (detection bias) } \\
\text { All outcomes }\end{array}$ & Low risk & $\begin{array}{l}\text { Quote: "Patients and physicians were blinded to treatment protocol." "A mild } \\
\text { synthetic lemon fragrance not containing citral was added to scent the iodine } \\
\text { olive oil preparation." }\end{array}$ \\
\hline
\end{tabular}

\begin{tabular}{|c|c|c|}
\hline $\begin{array}{l}\text { Incomplete outcome data } \\
\text { (attrition bias) } \\
\text { Short-term outcomes (up } \\
\text { to } 3 \text { months) }\end{array}$ & Low risk & $\begin{array}{l}\text { 5/53 participants (less than 20\%) were lost to follow-up (Markum 2012, from } \\
\text { Table } 1 \text { of publication). }\end{array}$ \\
\hline $\begin{array}{l}\text { Incomplete outcome data } \\
\text { (attrition bias) }\end{array}$ & Unclear risk & No long-term data \\
\hline
\end{tabular}


Markum 2012 (Continued)

Medium- and long-term

outcomes (3-6 months and

longer)

\begin{tabular}{lll}
\hline $\begin{array}{l}\text { Selective reporting (re- } \\
\text { porting bias) }\end{array}$ & Low risk & Reported outcomes similar to those mentioned in trial register \\
\hline Other bias & Unclear risk & No baseline comparison. No compliance data \\
\hline
\end{tabular}

Ohkuma 1990

$\begin{array}{ll}\text { Methods } & \text { Randomised controlled trial (written correspondence Dr Ohkuma), the method of generation of ran- } \\ \text { domisation sequence remained unclear, as was the concealment of allocation. It was also unclear if } \\ \text { participants were analysed according to the group to which they were randomised (intention-to-treat } \\ \text { analysis) and how blinding was performed. }\end{array}$

\begin{tabular}{ll}
\hline Participants & $\begin{array}{l}35 \text { patients with molluscum contagiosum, aged between } 2 \text { and } 9 \text { years (M/F: 21/14), Japan, Department } \\
\text { of Dermatology }\end{array}$ \\
\hline Interventions & $\begin{array}{l}3 \text { interventions were compared: } 10 \% \text { povidone iodine solution combined with } 50 \% \text { salicylic acid plaster } \\
(n=20), \text { iodine alone }(n=5), \text { and salicylic plaster alone }(n=10) .\end{array}$
\end{tabular}

\begin{tabular}{ll}
\hline Outcomes & Time to cure. Study duration unknown, but paper indicated that treatment continued as long as neces- \\
& sary; range was 7 to 64 days; mean 26 days for iodine + plaster, 86 days for iodine only, and 47 days for \\
& plaster only.
\end{tabular}

\begin{tabular}{ll}
\hline Notes & No baseline comparison, no compliance data \\
& Funding: not mentioned
\end{tabular}

\section{Risk of bias}

\begin{tabular}{lll}
\hline Bias & Authors' judgement & Support for judgement \\
\hline $\begin{array}{l}\text { Random sequence genera- } \\
\text { tion (selection bias) }\end{array}$ & Unclear risk & $\begin{array}{l}\text { Randomised (personal communication, not in paper). Insufficient information } \\
\text { about the sequence generation }\end{array}$ \\
\hline $\begin{array}{l}\text { Allocation concealment } \\
\text { (selection bias) }\end{array}$ & Unclear risk & Insufficient information \\
\hline $\begin{array}{l}\text { Blinding of participants } \\
\text { and personnel (perfor- } \\
\text { mance bias) } \\
\text { All outcomes }\end{array}$ & High risk & lodine versus salicylic plaster: hard to mask \\
\hline
\end{tabular}

\begin{tabular}{ll}
\hline Blinding of outcome as- & High risk $\quad$ lodine versus salicylic plaster: hard to mask \\
sessment (detection bias) &
\end{tabular}

All outcomes

Incomplete outcome data Low risk

(attrition bias)

Short-term outcomes (up

to 3 months)
No loss reported, all participants in outcome table. Follow-up period unclear. Duration of treatment ranged from 7 to 64 days.

Incomplete outcome data Unclear risk $\quad$ No medium- or long-term follow-up
(attrition bias)


Ohkuma 1990 (Continued)

Medium- and long-term

outcomes (3-6 months and

longer)

\begin{tabular}{|c|c|c|}
\hline $\begin{array}{l}\text { Selective reporting (re- } \\
\text { porting bias) }\end{array}$ & Unclear risk & Unclear \\
\hline Other bias & Unclear risk & $\begin{array}{l}\text { Quote: "In the former, two girls and three boys between the age of } 3 \text { and } 5 \\
\text { were included and } 4 \text { girls and } 6 \text { boys between } 2 \text { and } 9 \text { comprised the latter } \\
\text { control group." No imbalance for sex. No compliance data }\end{array}$ \\
\hline
\end{tabular}

\section{Ormerod 1999}

\begin{tabular}{ll}
\hline Methods & Group sequential double-blind randomised trial \\
\hline Participants & $\begin{array}{l}30 \text { molluscum patients were enrolled, } 16 \text { in the acidified nitrite group and } 14 \text { controls, with a median } \\
\text { age of } 6 \text { years, } 22 \text { girls and } 8 \text { boys. UK, Department of Dermatology }\end{array}$ \\
\hline Interventions & $\begin{array}{l}5 \% \text { sodium nitrite co-applied daily with } 5 \% \text { salicylic acid under occlusion versus identical cream with } \\
5 \% \text { salicylic acid omitting sodium nitrite, for } 3 \text { months }\end{array}$ \\
\hline Outcomes & Time to complete resolution, adverse events, study duration 3 months \\
\hline Notes & No baseline imbalance for duration and number of lesions, no compliance data. \\
& Funding: not mentioned \\
\hline
\end{tabular}

\section{Risk of bias}

\begin{tabular}{lll} 
Bias & Authors' judgement & Support for judgement \\
\hline $\begin{array}{l}\text { Random sequence genera- } \\
\text { tion (selection bias) }\end{array}$ & Unclear risk & $\begin{array}{l}\text { Quote: "Group sequential design in which subjects were randomised to receive } \\
\text { either"; insufficient information about the sequence generation }\end{array}$ \\
\hline $\begin{array}{l}\text { Allocation concealment } \\
\text { (selection bias) }\end{array}$ & Unclear risk & Method of concealment not described. \\
\hline $\begin{array}{l}\text { Blinding of participants } \\
\text { and personnel (perfor- } \\
\text { mance bias) }\end{array}$ & High risk & $\begin{array}{l}\text { Quote: "Double-blind, group sequential design in which subjects were ran- } \\
\text { domised to receive either } 5 \% \text { sodium nitrite co-applied with } 5 \% \text { salicylic acid } \\
\text { under occlusion, or identical cream with } 5 \% \text { salicylic acid but omitting sodium } \\
\text { nitrite, as a control." Not done, active intervention was associated with brown } \\
\text { staining. }\end{array}$ \\
\hline $\begin{array}{l}\text { Blinding of outcome as- } \\
\text { sessment (detection bias) } \\
\text { All outcomes }\end{array}$ & High risk & $\begin{array}{l}\text { Quote: "Double-blind, group sequential design in which subjects were ran- } \\
\text { domised to receive either } 5 \% \text { sodium nitrite co-applied with } 5 \% \text { salicylic acid } \\
\text { under occlusion, or identical cream with } 5 \% \text { salicylic acid but omitting sodium } \\
\text { nitrite, as a control." Not done, active intervention was associated with brown } \\
\text { staining. }\end{array}$ \\
\hline
\end{tabular}

Incomplete outcome data Unclear risk Only long-term data

(attrition bias)

Short-term outcomes (up

to 3 months)

$\begin{aligned} & \text { Incomplete outcome data } \\ & \text { (attrition bias) }\end{aligned}$
High risk $\quad 21 / 30$ dropouts after 3 months $(>30 \%)$


Ormerod 1999 (Continued)

Medium- and long-term

outcomes (3-6 months and

longer)

\begin{tabular}{lll}
\hline $\begin{array}{l}\text { Selective reporting (re- } \\
\text { porting bias) }\end{array}$ & Unclear risk & Unclear \\
\hline Other bias & Unclear risk & $\begin{array}{l}\text { No compliance data. Duration and number of lesions were very similar (com- } \\
\text { munication with author). }\end{array}$ \\
\hline
\end{tabular}

\section{Paller 2005a}

\begin{tabular}{ll}
\hline Methods & Randomised controlled trial \\
\hline Participants & $\begin{array}{l}125 \text { children, } 1 \text { to } 12 \text { years of age, with molluscum contagiosum in } 9 \text { outpatient clinics in the USA and } \\
\text { Canada were randomised. }\end{array}$ \\
\hline Interventions & Imiquimod cream $5 \%$ vs vehicle cream daily for 8 weeks \\
\hline Outcomes & $\begin{array}{l}\text { Lesion clearance, lesion counts, time to complete clearance, side effects, } 12 \text { weeks after start of treat- } \\
\text { ment }\end{array}$ \\
\hline Notes & Funding by pharmaceutical company (3M), unpublished
\end{tabular}

\section{Risk of bias}

\begin{tabular}{lll}
\hline Bias & Authors' judgement & Support for judgement \\
\hline $\begin{array}{l}\text { Random sequence genera- } \\
\text { tion (selection bias) }\end{array}$ & Low risk & $\begin{array}{l}\text { "Subjects were randomly assigned to a treatment arm in blocks of } 4 \text { according } \\
\text { to a computer-generated randomizations." (p.32) }\end{array}$ \\
\hline
\end{tabular}

\begin{tabular}{|c|c|c|}
\hline $\begin{array}{l}\text { Allocation concealment } \\
\text { (selection bias) }\end{array}$ & Low risk & $\begin{array}{l}\text { "Subjects/legal parental custodian(s) and investigators were unaware of the } \\
\text { study assignment" (p.25) } \\
\text { "This was a double-blind, vehicle-controlled study. } 3 \mathrm{M} \text { held the master code } \\
\text { for the treatment randomizations schedule and supplied the investigators } \\
\text { with each subject's randomizations code as a hidden (tear-off) disclosure pan- } \\
\text { el on the study cream carton label. The randomizations code for an individual } \\
\text { subject was to be broken only in case of an emergency, such as a serious ad- } \\
\text { verse event (SAE)." (p.34) }\end{array}$ \\
\hline $\begin{array}{l}\text { Blinding of participants } \\
\text { and personnel (perfor- } \\
\text { mance bias) } \\
\text { All outcomes }\end{array}$ & Low risk & See allocation concealment. \\
\hline
\end{tabular}

Blinding of outcome as-
sessment (detection bias)

\begin{tabular}{|c|c|c|}
\hline $\begin{array}{l}\text { Incomplete outcome data } \\
\text { (attrition bias) } \\
\text { Short-term outcomes (up } \\
\text { to } 3 \text { months) }\end{array}$ & Low risk & Not applicable: primary analysis by intention-to-treat \\
\hline $\begin{array}{l}\text { Incomplete outcome data } \\
\text { (attrition bias) }\end{array}$ & Unclear risk & No long-term outcomes \\
\hline
\end{tabular}


Paller 2005a (Continued) Medium- and long-term outcomes (3-6 months and longer)

\begin{tabular}{lll}
\hline $\begin{array}{l}\text { Selective reporting (re- } \\
\text { porting bias) }\end{array}$ & Low risk & All outcomes seem to have been reported. \\
\hline Other bias & Low risk & $\begin{array}{l}\text { No baseline imbalance, compliance data available, primary analysis by inten- } \\
\text { tion-to-treat }\end{array}$ \\
\hline
\end{tabular}

Paller 2005b

\begin{tabular}{ll}
\hline Methods & Randomised controlled trial \\
\hline Participants & $\begin{array}{l}379 \text { children, } 2 \text { to } 12 \text { years of age, with molluscum contagiosum in } 19 \text { outpatient clinics in the USA were } \\
\text { randomised. }\end{array}$ \\
\hline Interventions & Imiquimod cream $5 \%$ vs vehicle cream 3 times weekly for 16 weeks \\
\hline Outcomes & $\begin{array}{l}\text { Lesion clearance, lesion counts, time to complete clearance, side effects, 4, 8, 12, 16, 18, and 28 weeks } \\
\text { after start of treatment }\end{array}$ \\
\hline Notes & Funding by pharmaceutical company (3M), unpublished
\end{tabular}

\section{Risk of bias}

\begin{tabular}{lll}
\hline Bias & Authors' judgement & Support for judgement \\
\hline $\begin{array}{l}\text { Random sequence genera- } \\
\text { tion (selection bias) }\end{array}$ & Low risk & $\begin{array}{l}\text { "Subjects were randomly assigned to a treatment arm in blocks of } 6 \text { according } \\
\text { to a computer-generated randomizations schedule. Randomization was } 2: 1 \\
\text { (active:vehicle)" (p.40) }\end{array}$ \\
\hline $\begin{array}{l}\text { Allocation concealment } \\
\text { (selection bias) }\end{array}$ & Low risk & $\begin{array}{l}\text { "This was a double-blind, vehicle-controlled study; accordingly, the treatment } \\
\text { assignments were concealed from the subjects, investigators and study staff, } \\
\text { and the 3M clinical research team. The clinical packaging group at 3M Phar- } \\
\text { maceuticals held the master code for the treatment randomizations sched- } \\
\text { ule, and supplied the investigators with each subject's treatment assignment } \\
\text { as a hidden (tear-off) panel on the study cream label, which was affixed to the } \\
\text { blinded Drug Label page" (p.43) }\end{array}$
\end{tabular}

Blinding of participants Low risk See allocation concealment.
and personnel (perfor-
mance bias)
All outcomes

\begin{tabular}{lll}
\hline $\begin{array}{l}\text { Blinding of outcome as- } \\
\text { sessment (detection bias) } \\
\text { All outcomes }\end{array}$ & Low risk & \\
\hline $\begin{array}{l}\text { Incomplete outcome data } \\
\text { (attrition bias) }\end{array}$ & Low risk & Primary analysis by intention-to-treat \\
$\begin{array}{l}\text { Short-term outcomes (up } \\
\text { to } 3 \text { months) }\end{array}$ & \\
\hline $\begin{array}{l}\text { Incomplete outcome data } \\
\text { (attrition bias) }\end{array}$ & Low risk & $48 / 379$ discontinued, reasons were mentioned $(<30 \%)$.
\end{tabular}


Paller 2005b (Continued) Medium- and long-term outcomes (3-6 months and longer)

\begin{tabular}{lll}
\hline $\begin{array}{l}\text { Selective reporting (re- } \\
\text { porting bias) }\end{array}$ & Low risk & All outcomes seem to have been reported. \\
\hline Other bias & Low risk & $\begin{array}{l}\text { No baseline imbalances, reported on compliance, primary analysis by inten- } \\
\text { tion-to-treat }\end{array}$ \\
\hline
\end{tabular}

\section{Saryazdi 2004}

\begin{tabular}{ll}
\hline Methods & Randomised trial \\
\hline Participants & 30 children, age and sex unknown, Iran, hospital dermatology clinic \\
\hline Interventions & Topical benzoyl peroxide $10 \%$ cream versus tretinoin $0.05 \%$ cream, 2 times daily for 4 weeks \\
\hline Outcomes & Lesion count, lesion free, and side effects, 6 weeks after start of treatment \\
\hline Notes & $\begin{array}{l}\text { Information based on abstract; proportions cured used to estimate absolute numbers. Abstract pub- } \\
\text { lished in } 2004 ; \text { unclear when study was carried out. } \\
\text { Funding: not mentioned }\end{array}$ \\
\hline
\end{tabular}

\section{Risk of bias}

\begin{tabular}{|c|c|c|}
\hline Bias & Authors' judgement & Support for judgement \\
\hline $\begin{array}{l}\text { Random sequence genera- } \\
\text { tion (selection bias) }\end{array}$ & Unclear risk & Not reported \\
\hline $\begin{array}{l}\text { Allocation concealment } \\
\text { (selection bias) }\end{array}$ & Unclear risk & Not reported \\
\hline $\begin{array}{l}\text { Blinding of participants } \\
\text { and personnel (perfor- } \\
\text { mance bias) } \\
\text { All outcomes }\end{array}$ & Unclear risk & "Investigator masked"; no further details \\
\hline $\begin{array}{l}\text { Blinding of outcome as- } \\
\text { sessment (detection bias) } \\
\text { All outcomes }\end{array}$ & Unclear risk & "Investigator masked"; no further details \\
\hline $\begin{array}{l}\text { Incomplete outcome data } \\
\text { (attrition bias) } \\
\text { Short-term outcomes (up } \\
\text { to } 3 \text { months) }\end{array}$ & Unclear risk & Not reported \\
\hline $\begin{array}{l}\text { Incomplete outcome data } \\
\text { (attrition bias) } \\
\text { Medium- and long-term } \\
\text { outcomes ( } 3-6 \text { months and } \\
\text { longer) }\end{array}$ & Unclear risk & No medium- or long-term follow-up \\
\hline
\end{tabular}


Saryazdi 2004 (Continued)

Selective reporting (re- Unclear risk Efficacy was assessed at 2, 4, and 6 weeks, but the paper only reports results at porting bias) week 6.

Other bias Unclear risk No baseline characteristics or compliance data

Seo 2010

\begin{tabular}{ll}
\hline Methods & Randomised controlled trial \\
\hline Participants & 30 patients, 1 to 36 years of age, setting unclear, Korea \\
\hline Interventions & Imiquimod cream $5 \%$ versus potassium hydroxide solution $10 \%$ "for 3 months" (see Notes) \\
\hline Outcomes & Cure, adverse effects \\
\hline Notes & $\begin{array}{l}\text { Applied medication until all lesions were cleared. Mean duration of treatment }>4 \text { months; this is incon- } \\
\text { sistent with 'time after treatment'. } \\
\text { Funding: not mentioned }\end{array}$
\end{tabular}

\section{Risk of bias}

\begin{tabular}{|c|c|c|}
\hline Bias & Authors' judgement & Support for judgement \\
\hline $\begin{array}{l}\text { Random sequence genera- } \\
\text { tion (selection bias) }\end{array}$ & Unclear risk & Insufficient information \\
\hline $\begin{array}{l}\text { Allocation concealment } \\
\text { (selection bias) }\end{array}$ & Unclear risk & Insufficient information \\
\hline $\begin{array}{l}\text { Blinding of participants } \\
\text { and personnel (perfor- } \\
\text { mance bias) } \\
\text { All outcomes }\end{array}$ & High risk & Open study, method of application differed between treatment arms. \\
\hline $\begin{array}{l}\text { Blinding of outcome as- } \\
\text { sessment (detection bias) } \\
\text { All outcomes }\end{array}$ & High risk & Open study, so investigators were aware of treatment assignment. \\
\hline $\begin{array}{l}\text { Incomplete outcome data } \\
\text { (attrition bias) } \\
\text { Short-term outcomes (up } \\
\text { to } 3 \text { months) }\end{array}$ & Low risk & 3 participants lost to follow-up $(<20 \%)$ \\
\hline $\begin{array}{l}\text { Incomplete outcome data } \\
\text { (attrition bias) } \\
\text { Medium- and long-term } \\
\text { outcomes (3-6 months and } \\
\text { longer) }\end{array}$ & Low risk & 3 participants lost to follow-up $(<30 \%)$ \\
\hline $\begin{array}{l}\text { Selective reporting (re- } \\
\text { porting bias) }\end{array}$ & Unclear risk & No protocol available \\
\hline Other bias & Unclear risk & Imbalance in sex. No compliance data \\
\hline
\end{tabular}


Short 2006

\begin{tabular}{ll}
\hline Methods & Double-blind, randomised, placebo-controlled trial \\
\hline Participants & $\begin{array}{l}20 \text { children from a paediatric dermatology clinic, age range } 2 \text { to } 12 \text { years, M/F 6/14. UK, Department of } \\
\text { Dermatology, London }\end{array}$ \\
\hline Interventions & $\begin{array}{l}\text { Application of } 10 \% \text { potassium hydroxide solution twice daily applied with a cotton swab, continued un- } \\
\text { til the lesions showed signs of inflammation }(n=10) . \text { The control group received saline }(n=10), \text { for a } \\
\text { maximum of } 3 \text { months. }\end{array}$ \\
\hline Outcomes & Time to resolution, adverse events 3 months after start of treatment \\
\hline Notes & $\begin{array}{l}\text { Number of participants who completed the study differs between unpublished paper }(18 / 20) \text { and pub- } \\
\text { lished paper (19/20). Latter number included in corrected version of 2009 update (December 2009). }\end{array}$ \\
& Funding: not mentioned \\
\hline
\end{tabular}

\section{Risk of bias}

\begin{tabular}{|c|c|c|}
\hline Bias & Authors' judgement & Support for judgement \\
\hline $\begin{array}{l}\text { Random sequence genera- } \\
\text { tion (selection bias) }\end{array}$ & Unclear risk & $\begin{array}{l}\text { Quote: "The children were randomly allocated by the dispensing pharmacist } \\
\text { to receive one of two treatments". Insufficient information }\end{array}$ \\
\hline $\begin{array}{l}\text { Allocation concealment } \\
\text { (selection bias) }\end{array}$ & Low risk & $\begin{array}{l}\text { Quote: "The children were randomly allocated by the dispensing pharmacist } \\
\text { to receive one of two treatments." Central allocation: pharmacy controlled }\end{array}$ \\
\hline $\begin{array}{l}\text { Blinding of participants } \\
\text { and personnel (perfor- } \\
\text { mance bias) } \\
\text { All outcomes }\end{array}$ & Low risk & $\begin{array}{l}\text { Quote: "Both the patients and the observer were blinded". "Both solutions } \\
\text { were dispensed in identical, unlabeled bottles. The sequence was not revealed } \\
\text { until the end of the study." Staining and stinging reported in the potassium } \\
\text { hydroxide group. Participant, care provider, and outcome assessor probably } \\
\text { blinded. }\end{array}$ \\
\hline
\end{tabular}

\begin{tabular}{|c|c|c|}
\hline $\begin{array}{l}\text { Blinding of outcome as- } \\
\text { sessment (detection bias) } \\
\text { All outcomes }\end{array}$ & Low risk & $\begin{array}{l}\text { Quote: "Both the patients and the observer were blinded". "Both solutions } \\
\text { were dispensed in identical, unlabeled bottles. The sequence was not revealed } \\
\text { until the end of the study." Staining and stinging reported in the potassium } \\
\text { hydroxide group. Participant, care provider, and outcome assessor probably } \\
\text { blinded. }\end{array}$ \\
\hline
\end{tabular}

\begin{tabular}{|c|c|c|}
\hline $\begin{array}{l}\text { Incomplete outcome data } \\
\text { (attrition bias) } \\
\text { Short-term outcomes (up } \\
\text { to } 3 \text { months) }\end{array}$ & Low risk & $\begin{array}{l}2 \text { weeks: } 1 / 20 \text { did not complete study. } 1 / 10 \text { in the potassium hydroxide group } \\
\text { withdrew after } 2 \text { weeks because of discomfort of the skin localised to the ap- } \\
\text { plication site. }\end{array}$ \\
\hline
\end{tabular}

\begin{tabular}{lll}
\hline $\begin{array}{l}\text { Incomplete outcome data } \\
\text { (attrition bias) }\end{array}$ & Low risk \\
$\begin{array}{l}\text { Medium- and long-term } \\
\text { outcomes (3-6 months and } \\
\text { longer) }\end{array}$ & \\
\hline $\begin{array}{l}\text { Selective reporting (re- } \\
\text { porting bias) }\end{array}$ & Unclear risk & Unclear \\
\hline Other bias & Unclear risk & No baseline imbalance for sex, lesion site, and numbers. No compliance data \\
\hline
\end{tabular}


Theos 2004

\begin{tabular}{ll}
\hline Methods & Randomised controlled trial \\
\hline Participants & 23 children, 1 to 9 years of age, M/F 12/11, USA, Alabama, Illinois, New York \\
\hline Interventions & Imiquimod cream $5 \%$ or vehicle 3 times a week for 12 weeks \\
\hline Outcomes & $\begin{array}{l}\text { Complete or partial clearance ( }>30 \% \text { decrease from baseline lesion count), adverse events after } 4,8, \\
\text { and } 12 \text { weeks }\end{array}$ \\
\hline Notes & $\begin{array}{l}\text { Presented as a pilot study. Funding: not mentioned, but } 1 \text { of the authors was reported to be a consul- } \\
\text { funded by this company (Paller } 2005 a ; \text { Paller } 2005 b) .\end{array}$ \\
\hline
\end{tabular}

\section{Risk of bias}

\begin{tabular}{lll}
\hline Bias & Authors' judgement & Support for judgement \\
\hline $\begin{array}{l}\text { Random sequence genera- } \\
\text { tion (selection bias) }\end{array}$ & Unclear risk & $\begin{array}{l}\text { Quote: "Eligible patients were randomised to either imiquimod or vehicle". In- } \\
\text { sufficient information }\end{array}$ \\
\hline $\begin{array}{l}\text { Allocation concealment } \\
\text { (selection bias) }\end{array}$ & Unclear risk & $\begin{array}{l}\text { Quote: "Eligible patients were randomised to either imiquimod or vehicle". In- } \\
\text { sufficient information }\end{array}$ \\
\hline $\begin{array}{l}\text { Blinding of participants } \\
\text { and personnel (perfor- } \\
\text { mance bias) }\end{array}$ & Low risk & $\begin{array}{l}\text { Quote: "In a Double Blind, Randomized Pilot Trial"; "imiquimod vs vehicle". } \\
\text { All outcomes }\end{array}$ \\
\hline
\end{tabular}

$\begin{array}{lll}\begin{array}{l}\text { Blinding of outcome as- } \\ \text { sessment (detection bias) }\end{array} & \text { Low risk } & \begin{array}{l}\text { Quote: "In a Double Blind, Randomized Pilot Trial"; "imiquimod vs vehicle". } \\ \text { Only participants and physicians involved, so probably at low risk of bias. }\end{array}\end{array}$

All outcomes

Incomplete outcome data Low risk 2 weeks: $2 / 23$ did not complete the study (discontinued treatment)
(attrition bias)
Short-term outcomes (up
to 3 months)

\begin{tabular}{|c|c|c|}
\hline $\begin{array}{l}\text { Incomplete outcome data } \\
\text { (attrition bias) } \\
\text { Medium- and long-term } \\
\text { outcomes (3-6 months and } \\
\text { longer) }\end{array}$ & Unclear risk & No medium- or long-term follow-up \\
\hline $\begin{array}{l}\text { Selective reporting (re- } \\
\text { porting bias) }\end{array}$ & Unclear risk & Unclear \\
\hline Other bias & Unclear risk & $\begin{array}{l}\text { Baseline imbalance for mean lesion count, imiquimod: } 27.0 \text { versus vehicle: } \\
19.4 \text { (not statistically significant). No compliance data }\end{array}$ \\
\hline
\end{tabular}

Uçmak 2013

\begin{tabular}{ll}
\hline Methods & Randomised controlled trial \\
\hline Participants & 29 children, 15 months to 18 years of age, outpatient clinic, Turkey \\
\hline
\end{tabular}


Uçmak 2013 (Continued)

Interventions Potassium hydroxide $2.5 \%$ versus potassium hydroxide $5 \%$ twice daily for 60 days

\begin{tabular}{ll}
\hline Outcomes & Cure, adverse effects after $15,30,45$, and 60 days \\
\hline Notes & Funding: not mentioned, but authors report having no conflicts of interest.
\end{tabular}

\section{Risk of bias}

\begin{tabular}{|c|c|c|}
\hline Bias & Authors' judgement & Support for judgement \\
\hline $\begin{array}{l}\text { Random sequence genera- } \\
\text { tion (selection bias) }\end{array}$ & Unclear risk & No details except "randomised study" \\
\hline $\begin{array}{l}\text { Allocation concealment } \\
\text { (selection bias) }\end{array}$ & Unclear risk & No details \\
\hline $\begin{array}{l}\text { Blinding of participants } \\
\text { and personnel (perfor- } \\
\text { mance bias) } \\
\text { All outcomes }\end{array}$ & Low risk & $\begin{array}{l}\text { "The solution vials were indistinguishable, regardless of content, and were } \\
\text { stored at room temperature." But paper does not use the word 'blinded'. }\end{array}$ \\
\hline $\begin{array}{l}\text { Blinding of outcome as- } \\
\text { sessment (detection bias) } \\
\text { All outcomes }\end{array}$ & Unclear risk & Unclear whether outcome assessors were aware of treatment assignment \\
\hline $\begin{array}{l}\text { Incomplete outcome data } \\
\text { (attrition bias) } \\
\text { Short-term outcomes (up } \\
\text { to } 3 \text { months) }\end{array}$ & Low risk & $\begin{array}{l}1 \text { participant in potassium hydroxide } 2.5 \% \text { group and } 2 \text { participants in potas- } \\
\text { sium hydroxide } 5 \% \text { group "removed from study" due to irregular attendance } \\
\text { at follow-up visits. } 1 \text { further participant in potassium hydroxide } 5 \% \text { group quit } \\
\text { study due to excessive burning. Total number of loss to follow-up: } 4 / 29(<20 \%)\end{array}$ \\
\hline $\begin{array}{l}\text { Incomplete outcome data } \\
\text { (attrition bias) } \\
\text { Medium- and long-term } \\
\text { outcomes (3-6 months and } \\
\text { longer) }\end{array}$ & Unclear risk & No long-term outcomes \\
\hline $\begin{array}{l}\text { Selective reporting (re- } \\
\text { porting bias) }\end{array}$ & Unclear risk & No protocol \\
\hline Other bias & Unclear risk & No baseline comparison, no compliance data \\
\hline
\end{tabular}

$\mathrm{KOH}$ : potassium hydroxide

MC: molluscum contagiosum

NS: normal saline

Characteristics of excluded studies [ordered by study ID]

\begin{tabular}{ll}
\hline Study & Reason for exclusion \\
\hline Arican 2006 & Open-label study, imiquimod $5 \%$ cream $(n=12)$ \\
\hline Barton 2002 & HIV-infected patients $(n=40)$ \\
\hline Bayerl 2003 & Open-label study, imiquimod $5 \%$ cream $(n=13)$ \\
\hline
\end{tabular}




\begin{tabular}{ll}
\hline Study & Reason for exclusion \\
\hline Caballero 1996 & $\begin{array}{l}\text { RCT comparing } 2 \text { types of cryotherapy for cutaneous skin lesions; } 124 \text { participants, of which } 10 \\
\text { were molluscum patients, distributed 9:1 over } 2 \text { arms }\end{array}$ \\
\hline Can 2014 & Patient series, $10 \%$ potassium hydroxide $(n=40)$ \\
\hline Cathcart 2009 & Patient series, topical cantharidin ( $n=54)$ \\
\hline Chatproedrai 2007 & Pulsed dye laser $(n=20)$, not randomised (personal communication) \\
\hline de Waard 1990 & $\begin{array}{l}\text { Study on analgesic effect of lidocaine/prilocaine (EMLA) cream before physical therapy. Not a focus } \\
\text { of this review }(n=83)\end{array}$ \\
\hline
\end{tabular}

\begin{tabular}{ll}
\hline He 2001 & $\begin{array}{l}\text { Large parallel controlled study }(\mathrm{n}=1656) \text {, with } 4 \text { arms, no randomisation (personal communication } \\
\text { with Dr He through Taixiang Wu) }\end{array}$
\end{tabular}

Hengge $2000 \quad \begin{aligned} & \text { Open-label study, imiquimod } 5 \% \text { cream, no control group, patients with common warts or mollus- } \\ & \text { cum contagiosum }(n=65)\end{aligned}$

\begin{tabular}{ll}
\hline Holt 2011 & Patient series, topical treatment with Manuka honey $(\mathrm{n}=15)$ \\
\hline Juhlin 1980 & $\begin{array}{l}\text { Study on analgesic effect of lidocaine/prilocaine (EMLA) cream before physical therapy. Not a focus } \\
\text { of this review }(n=24)\end{array}$
\end{tabular}

\begin{tabular}{ll}
\hline $\operatorname{Lim} 2003$ & Patient series of topical 5\% imiquimod ( $n=4)$ \\
\hline Manchanda 1997a & $\begin{array}{l}\text { Cross-over study of patients with different types of warts }(n=43), 10 \text { molluscum patients. } 1 \text { of the } \\
\text { treatment arms (placebo first?) had fewer than } 2 \text { participants. }\end{array}$
\end{tabular}

\begin{tabular}{ll}
\hline Metkar 2008 & $\begin{array}{l}\text { Non-randomised, comparative study of imiquimod } 5 \% \text { cream versus 10\% potassium hydroxide ( } \mathrm{n}= \\
\text { Myhre } 2008\end{array}$ \\
\hline Open-label study, imiquimod $5 \%$ cream, no control group $(\mathrm{n}=22)$ \\
\hline Rosdahl 1988 & $\begin{array}{l}\text { Study on analgesic effect of lidocaine/prilocaine (EMLA) cream before physical therapy. Not a focus } \\
\text { of this review ( }=55)\end{array}$ \\
\hline Sadick 2009 & $\begin{array}{l}\text { Randomised split-face study in } 20 \text { patients with disseminated facial molluscum contagiosum and } \\
\text { HIV infection, not a focus of this review }\end{array}$ \\
\hline
\end{tabular}

\begin{tabular}{ll}
\hline Salmanpour 2006 & Not randomised but alternate assignment (personal communication, Alireza Firooz) \\
\hline Schalka 2010 & RCT comparing two topical analgesics before curettage $(n=40)$. Not a focus of this review \\
\hline Simonart 2008 & Not a randomised trial, curettage $(n=73)$ \\
\hline Skinner 2000 & Case report, 3 children, topical imiquimod $5 \%$ \\
\hline Syed 1994 & RCT, $n=150$, mainly genital lesions, not a focus of this review \\
\hline Syed 1998 & RCT, $n=100$, mainly genital lesions, not a focus of this review \\
\hline Weller 1999 & $\begin{array}{l}\text { Controlled trial }(n=16) \text { comparing phenol ablation and physical expression. Lesions were unit of } \\
\text { treatment and analysis. No randomisation }\end{array}$ \\
\hline
\end{tabular}




\section{Reason for exclusion}

Yabut-Catalasan 2003

Controlled trial $(n=34)$ of children aged 2 to 12 years. $10 \%$ potassium hydroxide versus placebo. Not randomised, but alternate assignment

$\mathrm{RCT}$ : randomised controlled trial

Characteristics of studies awaiting assessment [ordered by study ID]

Elzawahry 1964

Methods Unknown, no full-text paper and no abstract

\section{Participants}

Interventions

\section{Outcomes}

\section{Notes}

\section{Köse 2013}

\begin{tabular}{ll}
\hline Methods & Randomised trial \\
\hline Participants & Patients with molluscum contagiosum in Turkey \\
\hline Interventions & $10 \%$ potassium hydroxide solution versus salicylic and lactic acid combination \\
\hline Outcomes & Lesion response and side effects \\
\hline Notes & $\begin{array}{l}\text { Full text obtained August 2016. Email contact about unclear randomisations ("Patients were ran- } \\
\text { domised into two treatment groups according to appealing number." "The treatment groups } \\
\text { were not matched with the baseline characteristics because of the randomizations by application } \\
\text { rank." (p.301) (8 August 2016) }\end{array}$ \\
\hline
\end{tabular}

\begin{tabular}{|c|c|}
\hline Methods & Possibly randomised (participants were divided into 2 groups) \\
\hline Participants & Children aged 2 to 14 years with molluscum contagiosum in Pakistan \\
\hline Interventions & $5 \%$ or $10 \%$ potassium hydroxide solution \\
\hline Outcomes & Complete clearance, partial clearance, adverse effects \\
\hline Notes & $\begin{array}{l}\text { Summer 2016: asked author for additional information regarding randomisation (unclear from pa- } \\
\text { per) }\end{array}$ \\
\hline
\end{tabular}


NCT01348386

\begin{tabular}{ll}
\hline Methods & Double-blind, randomised clinical trial, in 3 groups \\
\hline Participants & $\begin{array}{l}\text { Children aged } 2 \text { to } 6 \text { years with molluscum contagiosum in Spain. Planned number of participants: } \\
60\end{array}$ \\
\hline Interventions & $\begin{array}{l}\text { Application of topical 10\% potassium hydroxide in an aqueous solution; 15\% potassium hydroxide; } \\
\text { placebo }\end{array}$ \\
\hline Outcomes & Primary outcome: efficacy (disappearance of lesions) after 60 days \\
\hline Notes & Email correspondence in January 2015: results are expected soon \\
\hline
\end{tabular}

\section{NCT02665260}

\begin{tabular}{|c|c|}
\hline \multirow[t]{6}{*}{ Methods } & From trial register: \\
\hline & Allocation: Randomized \\
\hline & Endpoint Classification: Safety/Efficacy Study \\
\hline & Intervention Model: Crossover Assignment \\
\hline & Masking: Double Blind (Subject, Caregiver, Investigator) \\
\hline & Primary Purpose: Treatment \\
\hline \multirow[t]{9}{*}{ Participants } & $n=100$ \\
\hline & Inclusion criteria: \\
\hline & - 2 to 17 years of age \\
\hline & - Healthy \\
\hline & - $<50$ molluscum contagiosum lesions \\
\hline & Exclusion criteria: \\
\hline & - Immunosuppressed \\
\hline & - Oral corticosteroids \\
\hline & - Sexually active/pregnant \\
\hline Interventions & $\begin{array}{l}\text { Cantharidin } 0.7 \% \text { topical, cantharidin } 0.7 \% \text { topical with occlusion, placebo, or placebo with occlu- } \\
\text { sion. Treatments were applied at weeks } 0 \text { and } 3 \text { (blinded phase). At week } 6 \text {, all participants were } \\
\text { treated with open-label, topical cantharidin } 0.7 \% \text { without occlusion every } 3 \text { weeks until all lesions } \\
\text { resolved (open-label phase). }\end{array}$ \\
\hline \multirow[t]{2}{*}{ Outcomes } & $\begin{array}{l}\text { Primary outcome measures: Percentage of participants who achieve complete clearance at } 6 \\
\text { weeks and } 33 \text { weeks [Time Frame: } 33 \text { weeks] [Designated as safety issue: No] Assess percentage } \\
\text { of participants who achieve a lesion count of zero at } 6 \text { weeks (end of blinded phase) and } 33 \text { weeks } \\
\text { (end of open-label phase) }\end{array}$ \\
\hline & $\begin{array}{l}\text { Secondary outcome measures: Frequency of adverse events [Time Frame: } 33 \text { weeks] [Designated } \\
\text { as safety issue: No] Assessed by patient-reported outcomes questionnaire at each visit }\end{array}$ \\
\hline Notes & Study completion date: January 2016 \\
\hline
\end{tabular}


Rajouria 2011

\begin{tabular}{ll}
\hline Methods & Randomised (abstract) or non-randomised (methods) controlled clinical trial \\
\hline Participants & Children with molluscum contagiosum in tertiary care centre in Nepal \\
\hline Interventions & $5 \%$ potassium hydroxide solution versus $0.05 \%$ tretinoin cream \\
\hline Outcomes & Number of lesions, local and systemic side effects \\
\hline Notes & $\begin{array}{l}\text { February 2015: asked author for additional information regarding randomisation (conflicting state- } \\
\text { ments in paper) }\end{array}$ \\
\hline
\end{tabular}

Tanissa 1951

Methods Unknown, no full-text paper or abstract

\section{Participants}

Interventions

\section{Outcomes}

\section{Notes}

Unknown Chinese author 1991

\begin{tabular}{ll}
\hline Methods $\quad$ Unknown, no full-text paper or abstract \\
\hline
\end{tabular}

\section{Participants}

Interventions

\section{Outcomes}

Notes

\section{Characteristics of ongoing studies [ordered by study ID]}

\section{NCT02024581}

Trial name or title
A Dose Range-Finding Phase 2 Trial of a Botanical Drug for the Treatment of Molluscum Contagiosum in Pediatric Subjects (original title, later changed to: A Single-center, Double-blind, Placebo-controlled, Randomized Safety and Efficacy Trial of a Botanical Drug Product, East Indian Sandalwood Oil (EISO), at One Dose Level for the Treatment of Molluscum Contagiosum in Pediatric Subjects

\begin{tabular}{ll}
\hline Methods & Double-blind, randomised controlled trial \\
\hline Participants & $\begin{array}{l}\text { Children } 2 \text { to } 17 \text { years of age with molluscum contagiosum, in Texas USA, planned number of par- } \\
\text { ticipants: } 60\end{array}$ \\
\hline
\end{tabular}


NCT02024581 (Continued)

\section{Outcomes}

The primary purpose of this study is to determine the safety profile of East Indian sandalwood. Safety will be assessed by evaluating adverse events with respect to severity, duration, and relationship to study drug compared to placebo.

Secondary outcomes: change in lesion count; improvement in Global Aesthetic Improvement Scale score; complete resolution of lesions; improvement in Evaluator's Global Severity Score.

\begin{tabular}{ll}
\hline Starting date & September 2015, estimated study completion date September 2016 \\
\hline Contact information & Dr John C Browning, drbrowning@texasdls.com \\
\hline Notes & $\begin{array}{l}\text { See History of Changes in trial register (duration changed from } 60 \text { to } 90 \text { days; upper age limit } \\
\text { changed; } 3 \text { strengths changed into 1; dates; title changed). Results of previously announced dose- } \\
\text { finding study unknown, asked by email July 2015. }\end{array}$ \\
\hline
\end{tabular}

\section{DATA AND ANALYSES}

\section{Comparison 1. Topical: $5 \%$ imiquimod versus vehicle}

\begin{tabular}{|c|c|c|c|c|}
\hline Outcome or subgroup title & No. of studies & $\begin{array}{l}\text { No. of partici- } \\
\text { pants }\end{array}$ & Statistical method & Effect size \\
\hline $\begin{array}{l}1 \text { Primary outcome: short-term clinical cure } \\
\text { (up to } 3 \text { months after start of treatment) }\end{array}$ & 4 & 850 & $\begin{array}{l}\text { Risk Ratio (M-H, Ran- } \\
\text { dom, } 95 \% \mathrm{Cl})\end{array}$ & $1.33[0.92,1.93]$ \\
\hline $\begin{array}{l}2 \text { Secondary outcome: medium-term clinical } \\
\text { cure (after } 3 \text { and up to } 6 \text { months after start } \\
\text { of treatment) }\end{array}$ & 2 & 702 & $\begin{array}{l}\text { Risk Ratio (M-H, Ran- } \\
\text { dom, } 95 \% \mathrm{Cl})\end{array}$ & $0.88[0.67,1.14]$ \\
\hline $\begin{array}{l}3 \text { Secondary outcome: long-term clinical } \\
\text { cure (> } 6 \text { months after start of treatment) }\end{array}$ & 2 & 702 & $\begin{array}{l}\text { Risk Ratio (M-H, Ran- } \\
\text { dom, } 95 \% \mathrm{Cl})\end{array}$ & $0.97[0.79,1.17]$ \\
\hline $\begin{array}{l}4 \text { Secondary outcome: short-term clinical } \\
\text { improvement (up to } 3 \text { months after start of } \\
\text { treatment) }\end{array}$ & 4 & 850 & $\begin{array}{l}\text { Risk Ratio (M-H, Ran- } \\
\text { dom, } 95 \% \mathrm{Cl})\end{array}$ & $1.14[0.89,1.47]$ \\
\hline $\begin{array}{l}5 \text { Secondary outcome: medium-term clinical } \\
\text { improvement (after } 3 \text { and up to } 6 \text { months af- } \\
\text { ter start of treatment) }\end{array}$ & 2 & 702 & $\begin{array}{l}\text { Risk Ratio (M-H, Ran- } \\
\text { dom, } 95 \% \mathrm{Cl})\end{array}$ & $0.97[0.87,1.08]$ \\
\hline 6 Secondary outcome: recurrence & 2 & 175 & $\begin{array}{l}\text { Risk Ratio (M-H, Ran- } \\
\text { dom, } 95 \% \mathrm{Cl})\end{array}$ & $2.70[0.31,23.23]$ \\
\hline 7 Secondary outcome: any side effect & 3 & 827 & $\begin{array}{l}\text { Risk Ratio (M-H, Ran- } \\
\text { dom, } 95 \% \mathrm{Cl})\end{array}$ & $0.97[0.88,1.07]$ \\
\hline $\begin{array}{l}8 \text { Secondary outcome: application site reac- } \\
\text { tion }\end{array}$ & 3 & 827 & $\begin{array}{l}\text { Risk Ratio (M-H, Ran- } \\
\text { dom, } 95 \% \mathrm{Cl})\end{array}$ & $1.41[1.13,1.77]$ \\
\hline $\begin{array}{l}9 \text { Secondary outcome: severe application } \\
\text { site reaction }\end{array}$ & 3 & 827 & $\begin{array}{l}\text { Risk Ratio (M-H, Ran- } \\
\text { dom, } 95 \% \mathrm{Cl})\end{array}$ & $4.33[1.16,16.19]$ \\
\hline
\end{tabular}


Analysis 1.1. Comparison 1 Topical: $5 \%$ imiquimod versus vehicle, Outcome 1 Primary outcome: short-term clinical cure (up to 3 months after start of treatment).

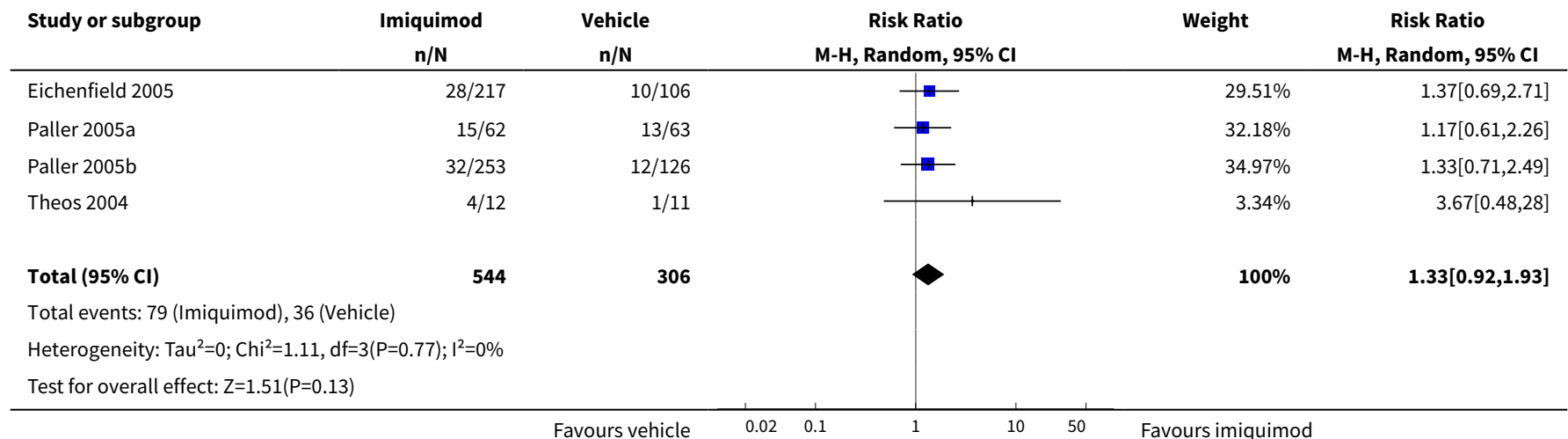

Analysis 1.2. Comparison 1 Topical: $5 \%$ imiquimod versus vehicle, Outcome 2 Secondary outcome: medium-term clinical cure (after 3 and up to 6 months after start of treatment).

\begin{tabular}{|c|c|c|c|c|c|}
\hline Study or subgroup & $\begin{array}{c}\text { Imiquimod } \\
\mathrm{n} / \mathrm{N}\end{array}$ & $\begin{array}{c}\text { Vehicle } \\
n / N\end{array}$ & $\begin{array}{c}\text { Risk Ratio } \\
\text { M-H, Random, } 95 \% \mathrm{Cl}\end{array}$ & Weight & $\begin{array}{c}\text { Risk Ratio } \\
\text { M-H, Random, } 95 \% \mathrm{CI}\end{array}$ \\
\hline Eichenfield 2005 & $52 / 217$ & $28 / 106$ & $\dashv$ & $44.91 \%$ & $0.91[0.61,1.35]$ \\
\hline Paller 2005b & $60 / 253$ & $35 / 126$ & & $55.09 \%$ & $0.85[0.6,1.22]$ \\
\hline Total $(95 \% \mathrm{Cl})$ & 470 & 232 & & $100 \%$ & $0.88[0.67,1.14]$ \\
\hline \multicolumn{6}{|c|}{ Total events: 112 (Imiquimod), 63 (Vehicle) } \\
\hline Test for overall effect & & & & & \\
\hline
\end{tabular}

Analysis 1.3. Comparison 1 Topical: $5 \%$ imiquimod versus vehicle, Outcome 3 Secondary outcome: long-term clinical cure (> 6 months after start of treatment).

\begin{tabular}{|c|c|c|c|c|c|}
\hline Study or subgroup & $\begin{array}{c}\text { Imiquimod } \\
\mathrm{n} / \mathrm{N}\end{array}$ & $\begin{array}{c}\text { Vehicle } \\
\mathrm{n} / \mathrm{N}\end{array}$ & $\begin{array}{c}\text { Risk Ratio } \\
\text { M-H, Random, 95\% Cl }\end{array}$ & Weight & $\begin{array}{c}\text { Risk Ratio } \\
\text { M-H, Random, } 95 \% \mathrm{CI}\end{array}$ \\
\hline Eichenfield 2005 & $89 / 217$ & $43 / 106$ & - & $48.82 \%$ & $1.01[0.76,1.34]$ \\
\hline Paller 2005b & $91 / 253$ & $49 / 126$ & & $51.18 \%$ & $0.92[0.7,1.22]$ \\
\hline Total $(95 \% \mathrm{CI})$ & 470 & 232 & & $100 \%$ & $0.97[0.79,1.17]$ \\
\hline \multicolumn{6}{|c|}{ Total events: 180 (Imiquimod), 92 (Vehicle) } \\
\hline Test for overall effect & & & & & \\
\hline
\end{tabular}


Analysis 1.4. Comparison 1 Topical: $5 \%$ imiquimod versus vehicle, Outcome 4 Secondary outcome: short-term clinical improvement (up to 3 months after start of treatment).

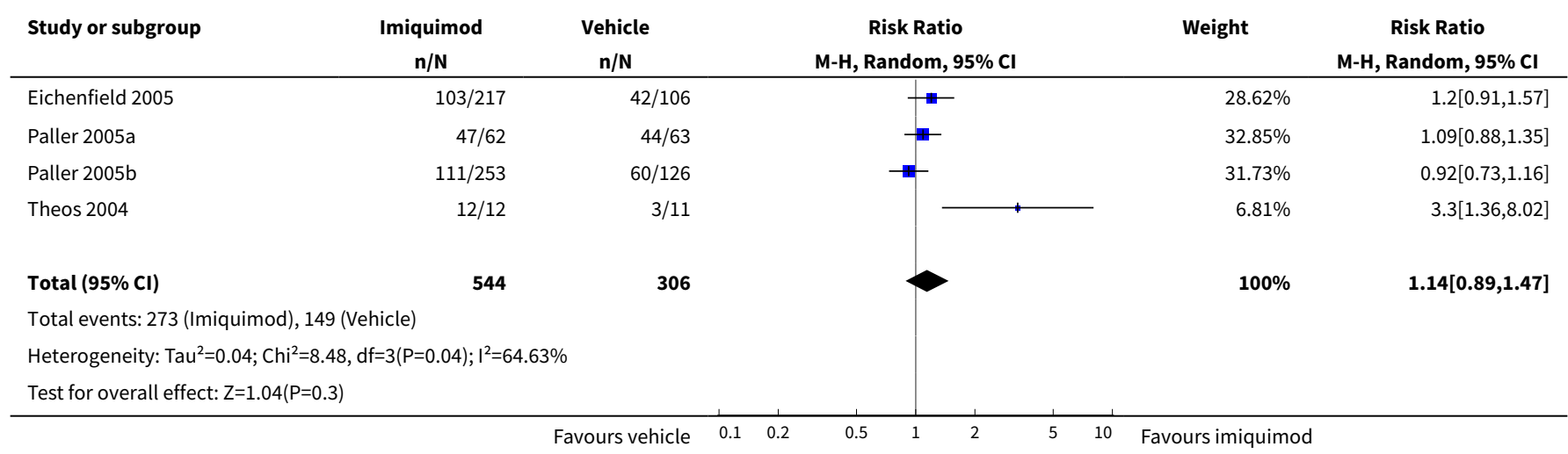

Analysis 1.5. Comparison 1 Topical: $5 \%$ imiquimod versus vehicle, Outcome 5 Secondary outcome: medium-term clinical improvement (after 3 and up to 6 months after start of treatment).

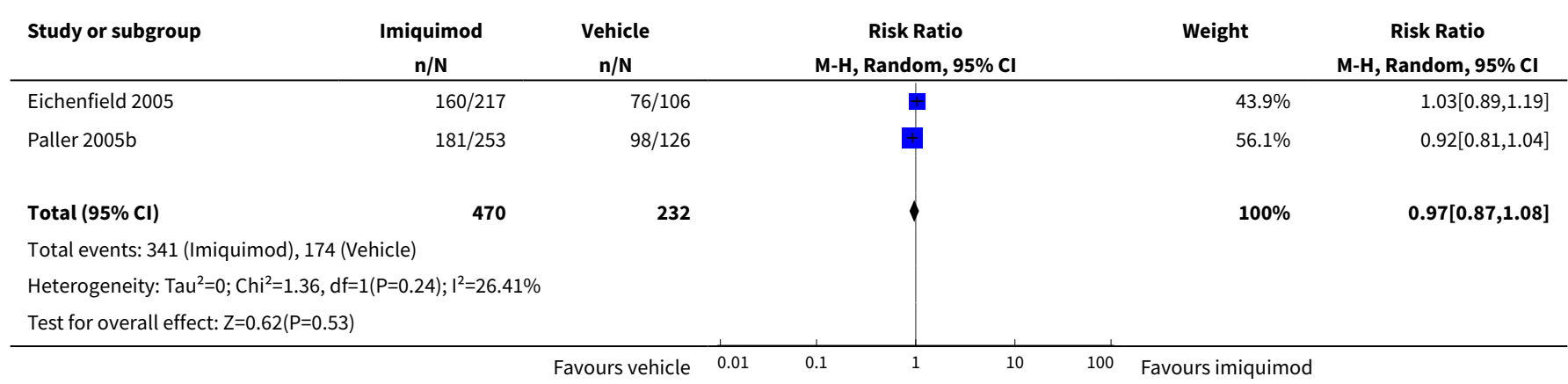

Analysis 1.6. Comparison 1 Topical: $5 \%$ imiquimod versus vehicle, Outcome 6 Secondary outcome: recurrence.

\begin{tabular}{|c|c|c|c|c|c|}
\hline Study or subgroup & $\begin{array}{c}\text { Imiquimod } \\
\mathrm{n} / \mathrm{N}\end{array}$ & $\begin{array}{c}\text { Vehicle } \\
\mathrm{n} / \mathrm{N}\end{array}$ & $\begin{array}{c}\text { Risk Ratio } \\
\text { M-H, Random, } 95 \% \mathrm{CI}\end{array}$ & Weight & $\begin{array}{c}\text { Risk Ratio } \\
\text { M-H, Random, } 95 \% \mathrm{CI}\end{array}$ \\
\hline Eichenfield 2005 & $1 / 52$ & $0 / 28$ & 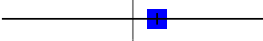 & $46.17 \%$ & $1.64[0.07,39.02]$ \\
\hline Paller 2005b & $3 / 60$ & $0 / 35$ & & $53.83 \%$ & $4.13[0.22,77.71]$ \\
\hline Total $(95 \% \mathrm{CI})$ & 112 & 63 & & $100 \%$ & $2.7[0.31,23.23]$ \\
\hline \multicolumn{6}{|c|}{ Total events: 4 (Imiquimod), 0 (Vehicle) } \\
\hline \multicolumn{6}{|c|}{ Test for overall effect: $Z=0.9(P=0.37)$} \\
\hline
\end{tabular}


Analysis 1.7. Comparison 1 Topical: $5 \%$ imiquimod versus vehicle, Outcome 7 Secondary outcome: any side effect.

\begin{tabular}{|c|c|c|c|c|c|}
\hline Study or subgroup & $\begin{array}{c}\text { Imiquimod } \\
\mathrm{n} / \mathrm{N}\end{array}$ & $\begin{array}{c}\text { Vehicle } \\
\mathbf{n} / \mathbf{N}\end{array}$ & $\begin{array}{c}\text { Risk Ratio } \\
\text { M-H, Random, } 95 \% \mathrm{Cl}\end{array}$ & Weight & $\begin{array}{c}\text { Risk Ratio } \\
\text { M-H, Random, } 95 \% \mathrm{Cl}\end{array}$ \\
\hline Eichenfield 2005 & $149 / 217$ & $78 / 106$ & - & $44.49 \%$ & $0.93[0.81,1.08]$ \\
\hline Paller 2005a & $42 / 62$ & $41 / 63$ & 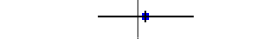 & $15.08 \%$ & $1.04[0.81,1.34]$ \\
\hline Paller 2005b & $166 / 253$ & $84 / 126$ & $\rightarrow$ & $40.44 \%$ & $0.98[0.85,1.15]$ \\
\hline Total $(95 \% \mathrm{Cl})$ & 532 & 295 & & $100 \%$ & $0.97[0.88,1.07]$ \\
\hline \multicolumn{6}{|c|}{ Heterogeneity: $\mathrm{Tau}^{2}=0 ; \mathrm{Chi}^{2}=0.62, \mathrm{df}=2(\mathrm{P}=0.73) ; \mathrm{I}^{2}=0 \%$} \\
\hline Test for overall effec & & & & & \\
\hline
\end{tabular}

Analysis 1.8. Comparison 1 Topical: $5 \%$ imiquimod versus vehicle, Outcome 8 Secondary outcome: application site reaction.

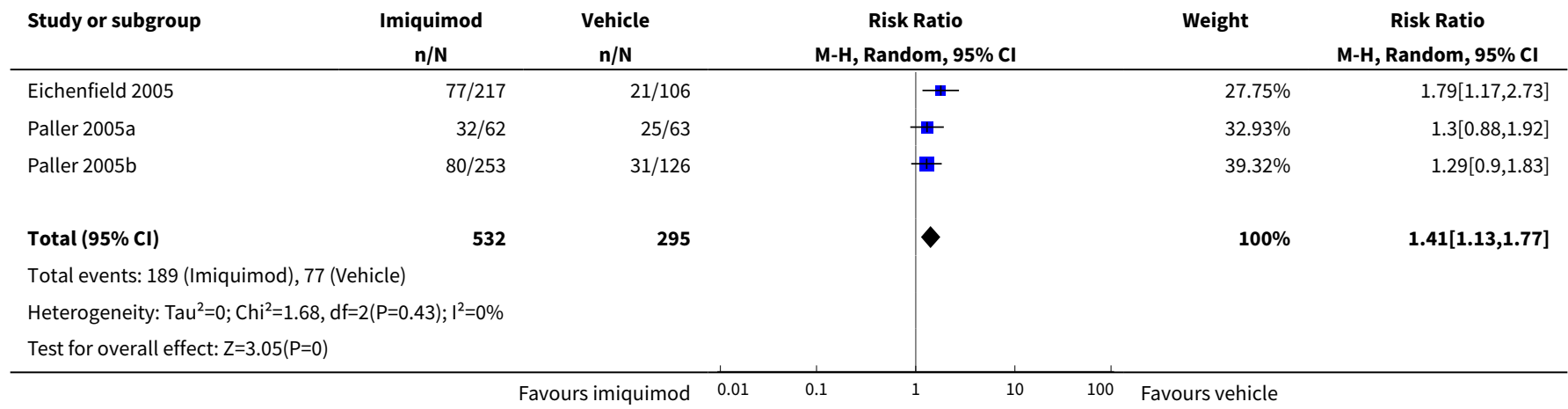

Analysis 1.9. Comparison 1 Topical: $5 \%$ imiquimod versus vehicle, Outcome 9 Secondary outcome: severe application site reaction.

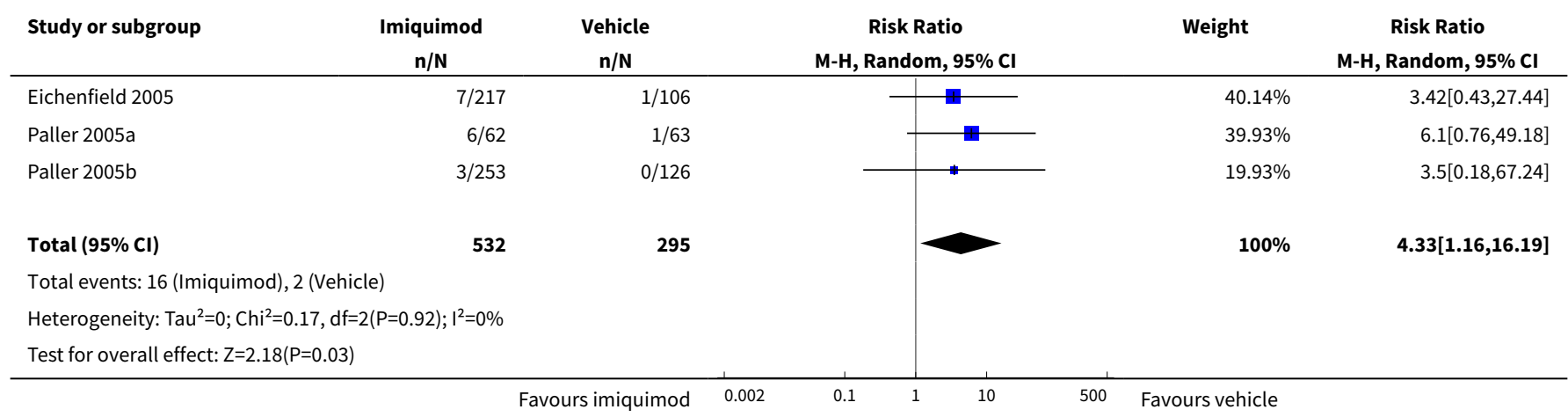


Comparison 2. Topical: $5 \%$ imiquimod versus cryospray

\begin{tabular}{|c|c|c|c|c|}
\hline Outcome or subgroup title & No. of studies & $\begin{array}{l}\text { No. of partici- } \\
\text { pants }\end{array}$ & Statistical method & Effect size \\
\hline $\begin{array}{l}1 \text { Primary outcome: short-term clinical cure } \\
\text { (up to } 3 \text { months after start of treatment) }\end{array}$ & 1 & & $\begin{array}{l}\text { Risk Ratio (M-H, Ran- } \\
\text { dom, } 95 \% \mathrm{Cl})\end{array}$ & $\begin{array}{l}\text { Totals not select- } \\
\text { ed }\end{array}$ \\
\hline $\begin{array}{l}2 \text { Secondary outcome: medium-term clinical } \\
\text { cure (after } 3 \text { and up to } 6 \text { months after start } \\
\text { of treatment) }\end{array}$ & 1 & & $\begin{array}{l}\text { Risk Ratio (M-H, Ran- } \\
\text { dom, } 95 \% \mathrm{Cl})\end{array}$ & Subtotals only \\
\hline 3 Secundary outcome: recurrence & 1 & & $\begin{array}{l}\text { Risk Ratio (M-H, Ran- } \\
\text { dom, } 95 \% \mathrm{Cl})\end{array}$ & $\begin{array}{l}\text { Totals not select- } \\
\text { ed }\end{array}$ \\
\hline
\end{tabular}

Analysis 2.1. Comparison 2 Topical: $5 \%$ imiquimod versus cryospray, Outcome 1 Primary outcome: short-term clinical cure (up to 3 months after start of treatment).

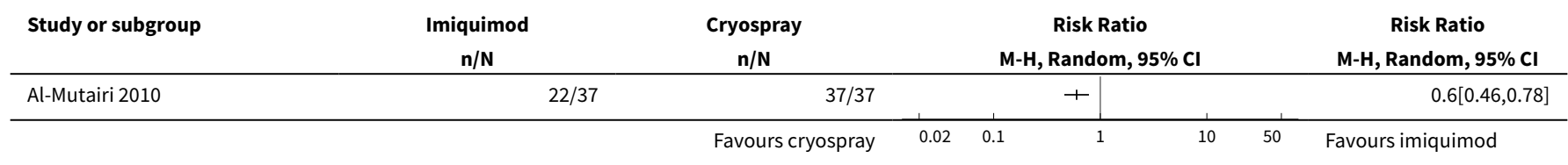

Analysis 2.2. Comparison 2 Topical: $5 \%$ imiquimod versus cryospray, Outcome 2 Secondary outcome: medium-term clinical cure (after 3 and up to 6 months after start of treatment).

\begin{tabular}{|c|c|c|c|c|c|}
\hline Study or subgroup & $\begin{array}{c}\text { Imiquimod } \\
\mathrm{n} / \mathrm{N}\end{array}$ & $\begin{array}{c}\text { Cryospray } \\
\mathrm{n} / \mathrm{N}\end{array}$ & $\begin{array}{c}\text { Risk Ratio } \\
\text { M-H, Random, } 95 \% \text { Cl }\end{array}$ & Weight & $\begin{array}{c}\text { Risk Ratio } \\
\text { M-H, Random, } 95 \% \mathrm{CI}\end{array}$ \\
\hline Al-Mutairi 2010 & $34 / 37$ & $37 / 37$ & 1 & $0 \%$ & $0.92[0.83,1.02]$ \\
\hline
\end{tabular}

Analysis 2.3. Comparison 2 Topical: $5 \%$ imiquimod versus cryospray, Outcome 3 Secundary outcome: recurrence.

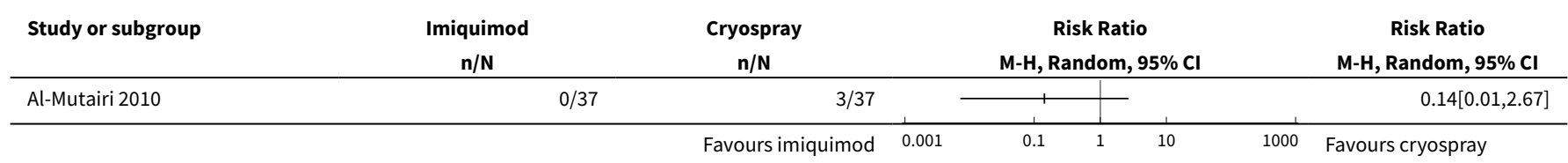

Comparison 3. Topical: $5 \%$ imiquimod versus $10 \%$ potassium hydroxide

\begin{tabular}{lllll}
\hline Outcome or subgroup title & No. of studies & $\begin{array}{l}\text { No. of partici- } \\
\text { pants }\end{array}$ & Statistical method & Effect size \\
\hline $\begin{array}{l}1 \text { Primary outcome: short-term clinical } \\
\begin{array}{l}\text { cure (up to 3 months after start of treat- } \\
\text { ment) }\end{array}\end{array}$ & 2 & 67 & $\begin{array}{l}\text { Risk Ratio (M-H, Random, } \\
95 \% \mathrm{Cl})\end{array}$ & $0.65[0.46,0.93]$ \\
\hline
\end{tabular}




\begin{tabular}{lllll}
\hline Outcome or subgroup title & No. of studies & $\begin{array}{l}\text { No. of partici- } \\
\text { pants }\end{array}$ & Statistical method & Effect size \\
\hline 2 Secondary outcome: any side effect & 2 & 67 & $\begin{array}{l}\text { Risk Ratio (M-H, Random, } \\
95 \% \mathrm{Cl})\end{array}$ & $0.68[0.25,1.81]$ \\
\hline
\end{tabular}

Analysis 3.1. Comparison 3 Topical: $5 \%$ imiquimod versus $10 \%$ potassium hydroxide, Outcome 1 Primary outcome: short-term clinical cure (up to 3 months after start of treatment).

\begin{tabular}{|c|c|c|c|c|c|}
\hline \multirow[t]{2}{*}{ Study or subgroup } & Imiquimod & $\begin{array}{l}\text { Potassium } \\
\text { hydroxide }\end{array}$ & Risk Ratio & Weight & \multirow{2}{*}{$\begin{array}{c}\text { Risk Ratio } \\
\text { M-H, Random, } 95 \% \mathrm{Cl}\end{array}$} \\
\hline & $n / N$ & $n / N$ & M-H, Random, $95 \% \mathrm{Cl}$ & & \\
\hline Chathra 2015 & $10 / 20$ & $17 / 20$ & $\because$ & $56.58 \%$ & $0.59[0.37,0.95]$ \\
\hline Seo 2010 & $8 / 14$ & $10 / 13$ & $\rightarrow$ & $43.42 \%$ & $0.74[0.43,1.28]$ \\
\hline Total $(95 \% \mathrm{Cl})$ & 34 & 33 & & $100 \%$ & $0.65[0.46,0.93]$ \\
\hline \multicolumn{6}{|c|}{ Heterogeneity: $\mathrm{Tau}^{2}=0 ; \mathrm{Chi}^{2}=0.4, \mathrm{df}=1(\mathrm{P}=0.53) ; \mathrm{I}^{2}=0 \%$} \\
\hline Test for overall effect & & & & & \\
\hline
\end{tabular}

Analysis 3.2. Comparison 3 Topical: $5 \%$ imiquimod versus $10 \%$ potassium hydroxide, Outcome 2 Secondary outcome: any side effect.

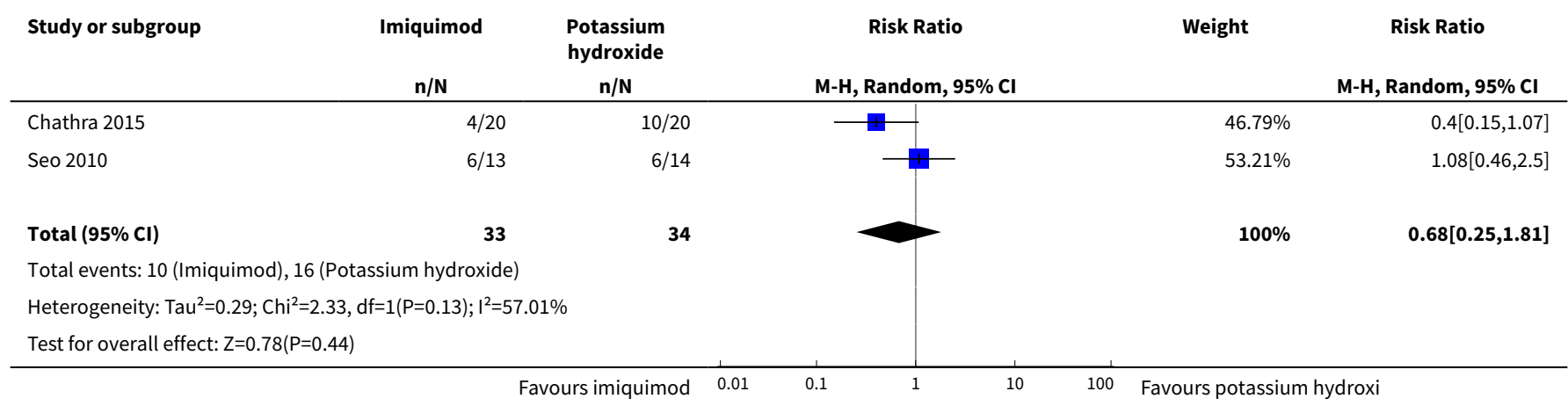

Comparison 4. Topical: $10 \%$ lemon myrtle oil versus vehicle

\begin{tabular}{lllll}
\hline Outcome or subgroup title & No. of studies & $\begin{array}{l}\text { No. of partici- } \\
\text { pants }\end{array}$ & Statistical method & Effect size \\
\hline $\begin{array}{l}1 \text { Primary outcome: short-term clinical cure } \\
\text { (up to } 3 \text { months after start of treatment) }\end{array}$ & 1 & Risk Ratio (M-H, Ran- & $\begin{array}{l}\text { Totals not select- } \\
\text { dom, 95\% Cl) }\end{array}$ & ed \\
\hline
\end{tabular}


Analysis 4.1. Comparison 4 Topical: $10 \%$ lemon myrtle oil versus vehicle, Outcome 1

Primary outcome: short-term clinical cure (up to 3 months after start of treatment).

\begin{tabular}{|c|c|c|c|c|c|c|}
\hline Study or subgroup & $\begin{array}{c}\text { Lemon myrtle oil } \\
\mathrm{n} / \mathrm{N}\end{array}$ & $\begin{array}{c}\text { Vehicle } \\
\mathrm{n} / \mathrm{N}\end{array}$ & & \multicolumn{2}{|c|}{$\begin{array}{c}\text { Risk Ratio } \\
\text { M-H, Random, } 95 \% \text { CI }\end{array}$} & \multirow{2}{*}{$\begin{array}{c}\text { Risk Ratio } \\
\text { M-H, Random, 95\% Cl } \\
17.88[1.13,282.72\end{array}$} \\
\hline Burke 2004 & $9 / 16$ & $0 / 15$ & & & & \\
\hline
\end{tabular}

Comparison 5 . Topical: $10 \%$ benzoyl peroxide cream versus $0.05 \%$ tretinoin cream

\begin{tabular}{lllll}
\hline Outcome or subgroup title & No. of studies & $\begin{array}{l}\text { No. of partici- } \\
\text { pants }\end{array}$ & Statistical method & Effect size \\
\hline $\begin{array}{l}\text { 1 Primary outcome: short-term clinical cure } \\
\text { (up to } 3 \text { months after start of treatment) }\end{array}$ & 1 & Risk Ratio (M-H, Ran- & $\begin{array}{l}\text { Totals not select- } \\
\text { dom, } 95 \% \mathrm{Cl})\end{array}$ & ed \\
\hline
\end{tabular}

Analysis 5.1. Comparison 5 Topical: $10 \%$ benzoyl peroxide cream versus $0.05 \%$ tretinoin cream, Outcome 1 Primary outcome: short-term clinical cure (up to 3 months after start of treatment).

\begin{tabular}{|c|c|c|c|c|c|c|c|}
\hline Study or subgroup & $\begin{array}{c}\text { benzoyl peroxide } \\
n / N\end{array}$ & $\begin{array}{c}\text { tretinoin } \\
\mathbf{n} / \mathbf{N}\end{array}$ & & & $\begin{array}{l}\text { Ratio } \\
\text { lom, } 95 \% \text { CI }\end{array}$ & & $\begin{array}{c}\text { Risk Ratio } \\
\text { M-H, Random, } 95 \% \mathrm{Cl}\end{array}$ \\
\hline \multirow[t]{2}{*}{ Saryazdi 2004} & $11 / 15$ & $5 / 15$ & & & 1 & & $2.2[1.01,4.79]$ \\
\hline & & Favours tretinoin & 0.01 & 0.1 & 10 & 100 & $\begin{array}{l}\text { Favours benzoyl perox- } \\
\text { ide }\end{array}$ \\
\hline
\end{tabular}

Comparison 6 . Topical: $10 \%$ potassium hydroxide versus saline

\begin{tabular}{lllll}
\hline Outcome or subgroup title & No. of studies & $\begin{array}{l}\text { No. of partici- } \\
\text { pants }\end{array}$ & Statistical method & Effect size \\
\hline $\begin{array}{l}1 \text { Primary outcome: short-term clinical cure } \\
\text { (up to } 3 \text { months after start of treatment) }\end{array}$ & 1 & Risk Ratio (M-H, Ran- & $\begin{array}{l}\text { Totals not select- } \\
\text { dom, } 95 \% \mathrm{Cl})\end{array}$ & ed \\
\hline
\end{tabular}

Analysis 6.1. Comparison 6 Topical: $10 \%$ potassium hydroxide versus saline, Outcome 1 Primary outcome: short-term clinical cure (up to 3 months after start of treatment).

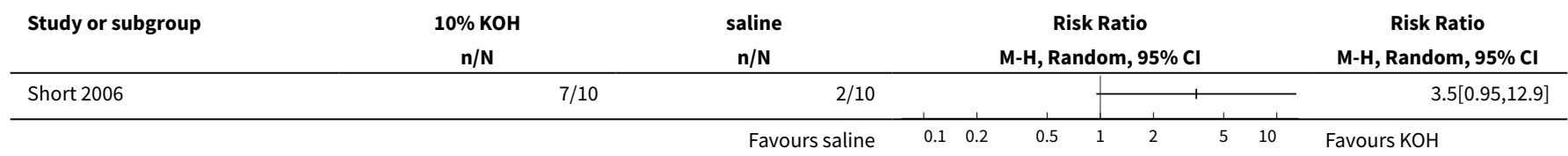


Comparison 7 . Topical: $2.5 \%$ potassium hydroxide versus $5 \%$ potassium hydroxide

\begin{tabular}{lllll}
\hline Outcome or subgroup title & No. of studies & $\begin{array}{l}\text { No. of partici- } \\
\text { pants }\end{array}$ & Statistical method & Effect size \\
\hline $\begin{array}{l}1 \text { Primary outcome: short-term clinical cure } \\
\text { (up to 3 months after start of treatment) }\end{array}$ & 1 & $\begin{array}{l}\text { Risk Ratio (M-H, Ran- } \\
\text { dom, 95\% Cl) }\end{array}$ & $\begin{array}{l}\text { Totals not select- } \\
\text { ed }\end{array}$ \\
\hline $\begin{array}{l}2 \text { Secondary outcome: short-term improve- } \\
\text { ment (up to 3 months after start of treatment) }\end{array}$ & 1 & $\begin{array}{l}\text { Risk Ratio (M-H, Ran- } \\
\text { dom, 95\% Cl) }\end{array}$ & $\begin{array}{l}\text { Totals not select- } \\
\text { ed }\end{array}$ \\
\hline
\end{tabular}

Analysis 7.1. Comparison 7 Topical: $2.5 \%$ potassium hydroxide versus $5 \%$ potassium hydroxide, Outcome 1 Primary outcome: short-term clinical cure (up to 3 months after start of treatment).

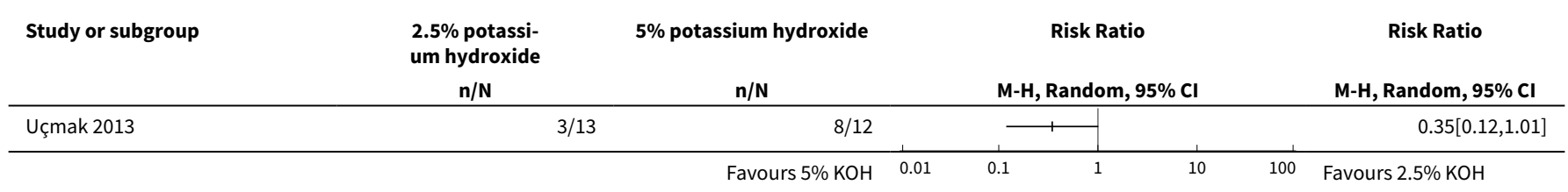

Analysis 7.2 . Comparison 7 Topical: $2.5 \%$ potassium hydroxide versus $5 \%$ potassium hydroxide, Outcome 2 Secondary outcome: short-term improvement (up to 3 months after start of treatment).

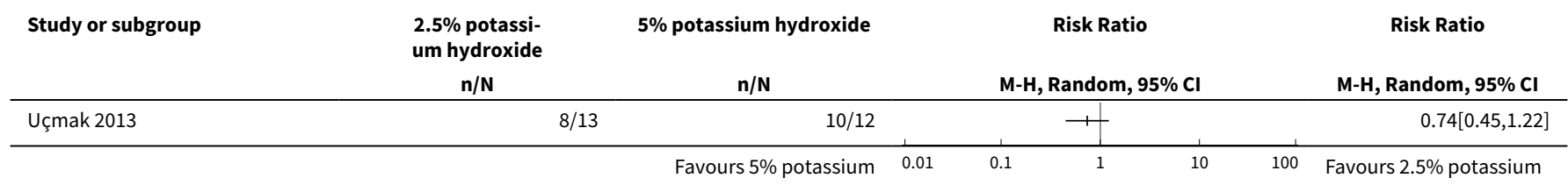

Comparison 8 . Topical: $10 \%$ potassium hydroxide versus $14 \%$ salicylic acid $+14 \%$ lactic acid

\begin{tabular}{lllll}
\hline Outcome or subgroup title & No. of studies & $\begin{array}{l}\text { No. of partici- } \\
\text { pants }\end{array}$ & Statistical method & Effect size \\
\hline $\begin{array}{l}1 \text { Primary outcome: short-term clinical cure } \\
\text { (up to } 3 \text { months after start of treatment) }\end{array}$ & 1 & & $\begin{array}{l}\text { Risk Ratio (M-H, Ran- } \\
\text { dom, 95\% Cl) }\end{array}$ & $\begin{array}{l}\text { Totals not select- } \\
\text { ed }\end{array}$ \\
\hline
\end{tabular}

Analysis 8.1. Comparison 8 Topical: $10 \%$ potassium hydroxide versus $14 \%$ salicylic acid $+14 \%$ lactic acid, Outcome 1 Primary outcome: short-term clinical cure (up to 3 months after start of treatment).

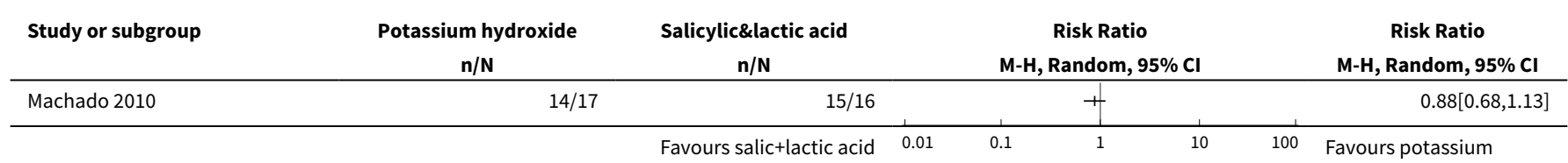


Comparison 9. Topical: $10 \%$ potassium hydroxide versus curettage

\begin{tabular}{lllll}
\hline Outcome or subgroup title & No. of studies & $\begin{array}{l}\text { No. of partici- } \\
\text { pants }\end{array}$ & Statistical method & Effect size \\
\hline $\begin{array}{l}1 \text { Primary outcome: short-term clinical cure } \\
\text { (up to } 3 \text { months after start of treatment) }\end{array}$ & 1 & Risk Ratio (M-H, Ran- & $\begin{array}{l}\text { Totals not select- } \\
\text { dom, 95\% Cl) }\end{array}$ & ed \\
\hline
\end{tabular}

Analysis 9.1. Comparison 9 Topical: $10 \%$ potassium hydroxide versus curettage, Outcome 1 Primary outcome: short-term clinical cure (up to 3 months after start of treatment).

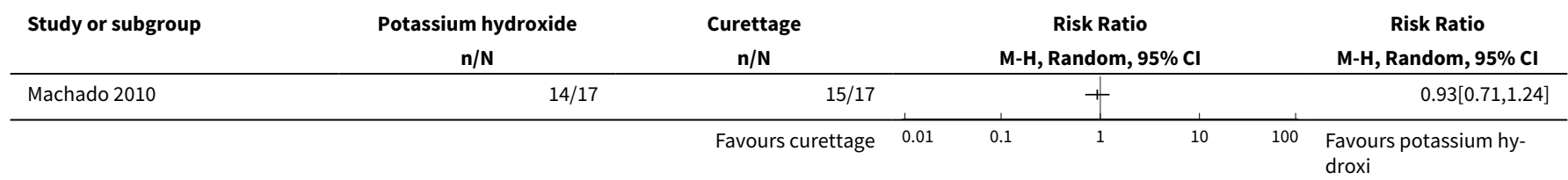

Comparison 10. Topical $10 \%$ potassium hydroxide versus cryotherapy

\begin{tabular}{lllll}
\hline Outcome or subgroup title & No. of studies & $\begin{array}{l}\text { No. of partici- } \\
\text { pants }\end{array}$ & Statistical method & Effect size \\
\hline $\begin{array}{l}1 \text { Primary outcome: short-term clinical cure (up } \\
\text { to } 3 \text { months after start of treatment) }\end{array}$ & 1 & $\begin{array}{l}\text { Risk Ratio (M-H, Ran- } \\
\text { dom, 95\% Cl) }\end{array}$ & $\begin{array}{l}\text { Totals not select- } \\
\text { ed }\end{array}$ \\
\hline $\begin{array}{l}2 \text { Secondary outcome: short-term clinical im- } \\
\text { provement (up to 3 months after start of treat- } \\
\text { ment) }\end{array}$ & 1 & $\begin{array}{l}\text { Risk Ratio (M-H, Ran- } \\
\text { dom, 95\% Cl) }\end{array}$ & $\begin{array}{l}\text { Totals not select- } \\
\text { ed }\end{array}$ \\
\hline
\end{tabular}

Analysis 10.1. Comparison 10 Topical $10 \%$ potassium hydroxide versus cryotherapy, Outcome 1 Primary outcome: short-term clinical cure (up to 3 months after start of treatment).

\begin{tabular}{|c|c|c|c|c|c|c|c|}
\hline Study or subgroup & $\begin{array}{c}\text { Potassium hydroxide } \\
\mathrm{n} / \mathrm{N}\end{array}$ & $\begin{array}{c}\text { Cryotherapy } \\
n / N\end{array}$ & & & & & $\begin{array}{c}\text { Risk Ratio } \\
\text { M-H, Random, } 95 \% \mathrm{Cl}\end{array}$ \\
\hline Handjani 2014 & $13 / 15$ & $14 / 15$ & & & & & $0.93[0.73,1.18]$ \\
\hline
\end{tabular}

Analysis 10.2. Comparison 10 Topical $10 \%$ potassium hydroxide versus cryotherapy, Outcome 2 Secondary outcome: short-term clinical improvement (up to 3 months after start of treatment).

\begin{tabular}{|c|c|c|c|c|}
\hline Study or subgroup & $\begin{array}{l}\text { Potassium hydroxide } \\
\mathrm{n} / \mathrm{N}\end{array}$ & $\begin{array}{c}\text { Cryotherapy } \\
\mathrm{n} / \mathrm{N}\end{array}$ & $\begin{array}{c}\text { Risk Ratio } \\
\text { M-H, Random, } 95 \% \text { Cl }\end{array}$ & $\begin{array}{c}\text { Risk Ratio } \\
\text { M-H, Random, } 95 \% \text { CI }\end{array}$ \\
\hline Handjani 2014 & $14 / 15$ & $15 / 15$ & + & $0.94[0.78,1.12]$ \\
\hline
\end{tabular}


Comparison 11. Topical: $10 \%$ povidone iodine versus $50 \%$ salicylic acid plaster

\begin{tabular}{lllll}
\hline Outcome or subgroup title & No. of studies & $\begin{array}{l}\text { No. of partici- } \\
\text { pants }\end{array}$ & Statistical method & Effect size \\
\hline $\begin{array}{l}1 \text { Primary outcome: short-term clinical cure } \\
\text { (up to } 3 \text { months after start of treatment) }\end{array}$ & 1 & Risk Ratio (M-H, Ran- & $\begin{array}{l}\text { Totals not select- } \\
\text { dom, 95\% Cl) }\end{array}$ & ed \\
\hline
\end{tabular}

Analysis 11.1. Comparison 11 Topical: $10 \%$ povidone iodine versus $50 \%$ salicylic acid plaster, Outcome 1 Primary outcome: short-term clinical cure (up to 3 months after start of treatment).

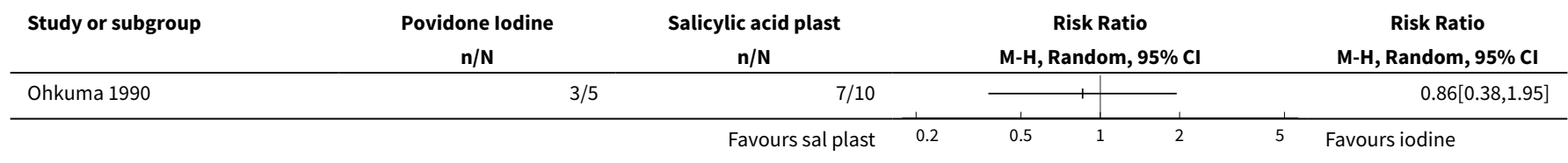

Comparison 12. Topical: $10 \%$ povidone iodine alone versus $10 \%$ povidone iodine and $50 \%$ salicylic plaster

\begin{tabular}{lllll}
\hline Outcome or subgroup title & No. of studies & $\begin{array}{l}\text { No. of partici- } \\
\text { pants }\end{array}$ & Statistical method & Effect size \\
\hline $\begin{array}{l}1 \text { Primary outcome: short-term clinical cure } \\
\text { (up to } 3 \text { months after start of treatment) }\end{array}$ & 1 & & $\begin{array}{l}\text { Risk Ratio (M-H, Ran- } \\
\text { dom, 95\% Cl) }\end{array}$ & $\begin{array}{l}\text { Totals not select- } \\
\text { ed }\end{array}$ \\
\hline
\end{tabular}

Analysis 12.1. Comparison 12 Topical: $10 \%$ povidone iodine alone versus $10 \%$ povidone iodine and $50 \%$ salicylic plaster, Outcome 1 Primary outcome: short-term clinical cure (up to 3 months after start of treatment).

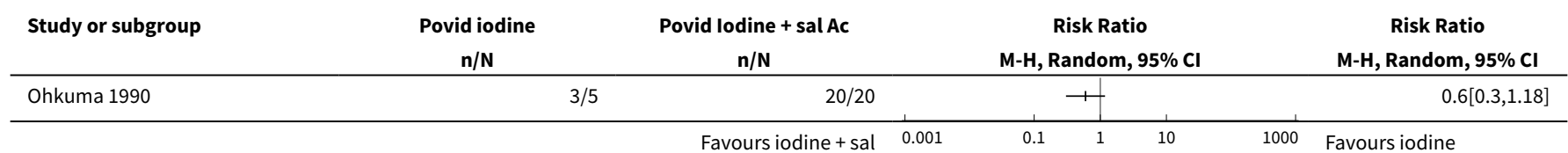

Comparison 13. Topical: $10 \%$ povidone iodine and $50 \%$ salicylic acid plaster versus $50 \%$ salicylic plaster alone

\begin{tabular}{lllll}
\hline Outcome or subgroup title & No. of studies & $\begin{array}{l}\text { No. of partici- } \\
\text { pants }\end{array}$ & Statistical method & Effect size \\
\hline $\begin{array}{l}1 \text { Primary outcome: short-term clinical cure } \\
\text { (up to 3 months after start of treatment) }\end{array}$ & 1 & & $\begin{array}{l}\text { Risk Ratio (M-H, Ran- } \\
\text { dom, 95\% Cl) }\end{array}$ & $\begin{array}{l}\text { Totals not select- } \\
\text { ed }\end{array}$ \\
\hline
\end{tabular}


Analysis 13.1. Comparison 13 Topical: $10 \%$ povidone iodine and $50 \%$ salicylic acid plaster versus $50 \%$ salicylic plaster alone, Outcome 1 Primary outcome: short-term clinical cure (up to 3 months after start of treatment).

\begin{tabular}{|c|c|c|c|c|c|c|}
\hline & $\begin{array}{c}\text { Iodine + Salicylic } \\
n / N\end{array}$ & $\begin{array}{c}\text { Salicylic alone } \\
n / N\end{array}$ & \multicolumn{3}{|c|}{$\begin{array}{c}\text { Risk Ratio } \\
\text { M-H, Random, } 95 \% \text { Cl }\end{array}$} & \multirow{2}{*}{$\begin{array}{c}\text { Risk Ratio } \\
\text { M-H, Random, 95\% Cl } \\
1.43[0.95,2.16\end{array}$} \\
\hline Ohkuma 1990 & $20 / 20$ & $7 / 10$ & & & 1 & \\
\hline
\end{tabular}

Comparison 14. Topical: $0.7 \%$ cantharidin versus vehicle

\begin{tabular}{lllll}
\hline Outcome or subgroup title & No. of studies & $\begin{array}{l}\text { No. of partici- } \\
\text { pants }\end{array}$ & Statistical method & Effect size \\
\hline $\begin{array}{l}1 \text { Primary outcome: short-term clinical cure } \\
\text { (up to } 3 \text { months after start of treatment). }\end{array}$ & 1 & Risk Ratio (M-H, Ran- & $\begin{array}{l}\text { Totals not select- } \\
\text { dom, } 95 \% \mathrm{Cl})\end{array}$ & ed \\
\hline
\end{tabular}

Analysis 14.1. Comparison 14 Topical: $0.7 \%$ cantharidin versus vehicle, Outcome 1 Primary outcome: short-term clinical cure (up to 3 months after start of treatment).

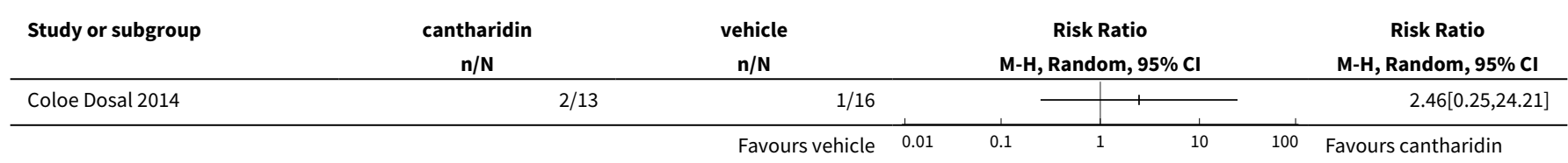

Comparison 15. Topical: $5 \%$ sodium nitrite in $5 \%$ salicylic acid versus $5 \%$ salicylic acid alone

\begin{tabular}{lllll}
\hline Outcome or subgroup title & No. of studies & $\begin{array}{l}\text { No. of partici- } \\
\text { pants }\end{array}$ & Statistical method & Effect size \\
\hline $\begin{array}{l}1 \text { Primary outcome: short-term clinical cure } \\
\text { (up to } 3 \text { months after start of treatment) }\end{array}$ & 1 & & $\begin{array}{l}\text { Risk Ratio (M-H, Ran- } \\
\text { dom, 95\% Cl) }\end{array}$ & $\begin{array}{l}\text { Totals not select- } \\
\text { ed }\end{array}$
\end{tabular}

Analysis 15.1. Comparison 15 Topical: $5 \%$ sodium nitrite in $5 \%$ salicylic acid versus $5 \%$ salicylic acid alone, Outcome 1 Primary outcome: short-term clinical cure (up to 3 months after start of treatment).

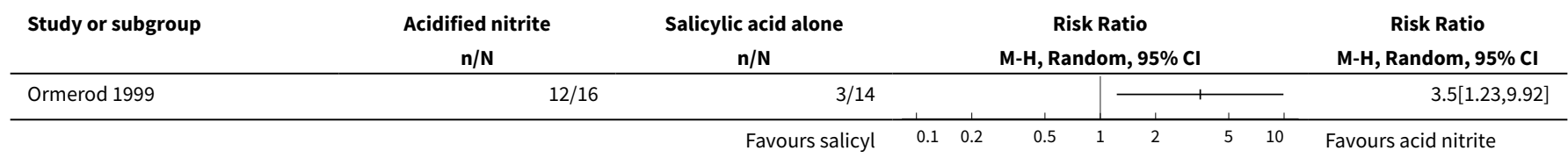


Comparison 16. Topical: $12 \%$ salicylic acid versus $70 \%$ alcohol

\begin{tabular}{lllll}
\hline Outcome or subgroup title & No. of studies & $\begin{array}{l}\text { No. of partici- } \\
\text { pants }\end{array}$ & Statistical method & Effect size \\
\hline $\begin{array}{l}1 \text { Secondary outcome: medium-term clinical } \\
\text { cure (after } 3 \text { and up to } 6 \text { months after start of } \\
\text { treatment) }\end{array}$ & 1 & Risk Ratio (M-H, Ran- & $\begin{array}{l}\text { Totals not select- } \\
\text { dom, 95\% Cl) }\end{array}$ & ed \\
\hline
\end{tabular}

Analysis 16.1. Comparison 16 Topical: $12 \%$ salicylic acid versus $70 \%$ alcohol, Outcome 1 Secondary outcome: medium-term clinical cure (after 3 and up to 6 months after start of treatment).

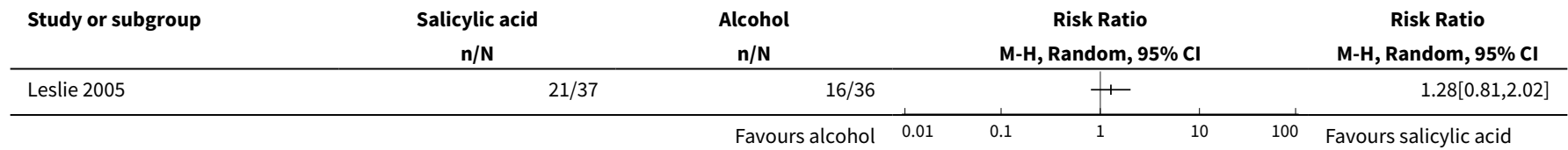

Comparison 17. Topical: $12 \%$ salicylic acid versus $10 \%$ phenol $/ 70 \%$ alcohol

\begin{tabular}{lllll}
\hline Outcome or subgroup title & No. of studies & $\begin{array}{l}\text { No. of partici- } \\
\text { pants }\end{array}$ & Statistical method & Effect size \\
\hline $\begin{array}{l}1 \text { Secondary outcome: medium-term clinical } \\
\text { cure (after } 3 \text { and up to } 6 \text { months after start of } \\
\text { treatment) }\end{array}$ & 1 & Risk Ratio (M-H, Ran- & $\begin{array}{l}\text { Totals not select- } \\
\text { dom, } 95 \% \text { Cl) }\end{array}$ & \\
\hline
\end{tabular}

Analysis 17.1. Comparison 17 Topical: $12 \%$ salicylic acid versus $10 \%$ phenol $/ 70 \%$ alcohol, Outcome 1 Secondary outcome: medium-term clinical cure (after 3 and up to 6 months after start of treatment).

\begin{tabular}{|c|c|c|c|c|c|c|c|}
\hline Study or subgroup & $\begin{array}{c}\text { Salicylic acid } \\
n / N\end{array}$ & $\begin{array}{c}\text { Phenol } \\
\mathrm{n} / \mathrm{N}\end{array}$ & & & $\begin{array}{l}\text { Ratio } \\
\text { lom, } 95 \% \mathrm{Cl}\end{array}$ & & $\begin{array}{c}\text { Risk Ratio } \\
\text { M-H, Random, } 95 \% \mathrm{CI}\end{array}$ \\
\hline Leslie 2005 & $21 / 37$ & $17 / 41$ & & & + & & $1.37[0.86,2.17]$ \\
\hline
\end{tabular}

Comparison 18 . Topical: $14 \%$ salicylic acid $+14 \%$ lactic acid versus curettage

\begin{tabular}{lllll}
\hline Outcome or subgroup title & No. of studies & $\begin{array}{l}\text { No. of partici- } \\
\text { pants }\end{array}$ & Statistical method & Effect size \\
\hline $\begin{array}{l}1 \text { Primary outcome: short-term clinical cure } \\
\text { (up to } 3 \text { months after start of treatment) }\end{array}$ & 1 & Risk Ratio (M-H, Ran- & $\begin{array}{l}\text { Totals not select- } \\
\text { dom, 95\% Cl) }\end{array}$ & ed \\
\hline
\end{tabular}


Analysis 18.1. Comparison 18 Topical: $14 \%$ salicylic acid $+14 \%$ lactic acid versus curettage, Outcome 1 Primary outcome: short-term clinical cure (up to 3 months after start of treatment).

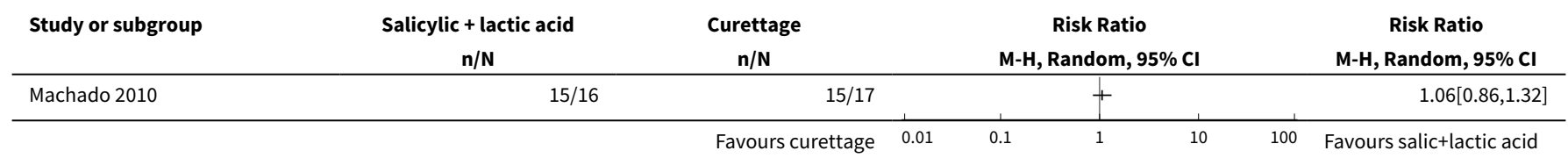

Comparison 19. Topical: $70 \%$ alcohol versus $10 \%$ phenol $/ 70 \%$ alcohol

\begin{tabular}{lllll}
\hline Outcome or subgroup title & No. of studies & $\begin{array}{l}\text { No. of partici- } \\
\text { pants }\end{array}$ & Statistical method & Effect size \\
\hline $\begin{array}{l}1 \text { Secondary outcome: medium-term clinical } \\
\text { cure (after } 3 \text { and up to } 6 \text { months after start of } \\
\text { treatment) }\end{array}$ & 1 & $\begin{array}{l}\text { Risk Ratio }(\mathrm{M}-\mathrm{H}, \text { Ran- } \\
\text { dom, } 95 \% \mathrm{Cl})\end{array}$ & $\begin{array}{l}\text { Totals not select- } \\
\text { ed }\end{array}$ \\
\hline
\end{tabular}

Analysis 19.1. Comparison 19 Topical: $70 \%$ alcohol versus $10 \%$ phenol/70\% alcohol, Outcome 1 Secondary outcome: medium-term clinical cure (after 3 and up to 6 months after start of treatment).

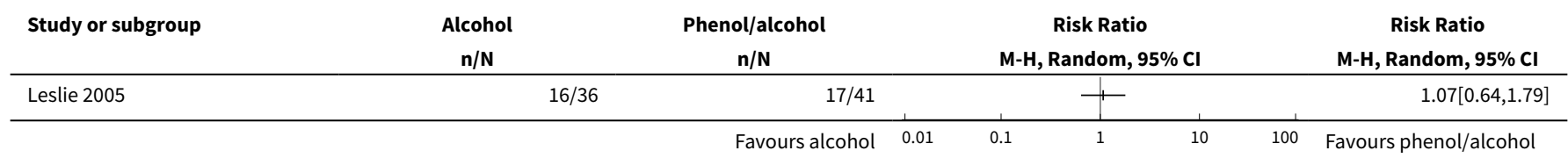

Comparison 20. Topical: iodine versus tea tree oil

\begin{tabular}{lllll}
\hline Outcome or subgroup title & No. of studies & $\begin{array}{l}\text { No. of partici- } \\
\text { pants }\end{array}$ & Statistical method & Effect size \\
\hline $\begin{array}{l}1 \text { Primary outcome: short-term clinical cure } \\
\text { (up to } 3 \text { months after start of treatment) }\end{array}$ & 1 & $\begin{array}{l}\text { Risk Ratio (M-H, Ran- } \\
\text { dom, 95\% Cl) }\end{array}$ & $\begin{array}{l}\text { Totals not select- } \\
\text { ed }\end{array}$ \\
\hline $\begin{array}{l}\text { 2 Secondary outcome: improvement (up to 3 } \\
\text { months after start of treatment) }\end{array}$ & 1 & Risk Ratio (M-H, Ran- & Totals not select- \\
dom, 95\% Cl) & ed & \\
\hline
\end{tabular}

Analysis 20.1. Comparison 20 Topical: iodine versus tea tree oil, Outcome 1 Primary outcome: short-term clinical cure (up to 3 months after start of treatment).

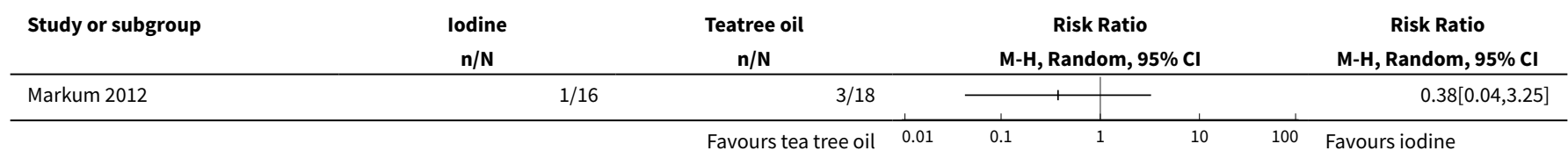


Analysis 20.2. Comparison 20 Topical: iodine versus tea tree oil, Outcome 2

Secondary outcome: improvement (up to 3 months after start of treatment).

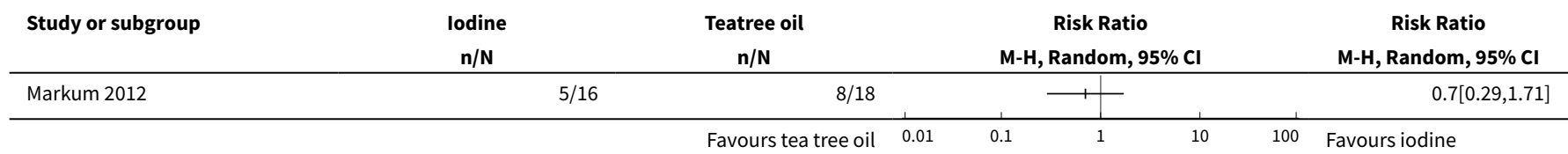

Comparison 21. Topical: iodine versus tea tree oil combined with iodine

\begin{tabular}{|c|c|c|c|c|}
\hline Outcome or subgroup title & No. of studies & $\begin{array}{l}\text { No. of partici- } \\
\text { pants }\end{array}$ & Statistical method & Effect size \\
\hline $\begin{array}{l}1 \text { Primary outcome: short-term clinical cure } \\
\text { (up to } 3 \text { months after start of treatment) }\end{array}$ & 1 & & $\begin{array}{l}\text { Risk Ratio (M-H, Ran- } \\
\text { dom, } 95 \% \mathrm{Cl})\end{array}$ & $\begin{array}{l}\text { Totals not select- } \\
\text { ed }\end{array}$ \\
\hline $\begin{array}{l}2 \text { Secondary outcome: improvement (up to } 3 \\
\text { months after start of treatment) }\end{array}$ & 1 & & $\begin{array}{l}\text { Risk Ratio (M-H, Ran- } \\
\text { dom, } 95 \% \mathrm{Cl})\end{array}$ & $\begin{array}{l}\text { Totals not select- } \\
\text { ed }\end{array}$ \\
\hline
\end{tabular}

Analysis 21.1. Comparison 21 Topical: iodine versus tea tree oil combined with iodine, Outcome 1 Primary outcome: short-term clinical cure (up to 3 months after start of treatment).

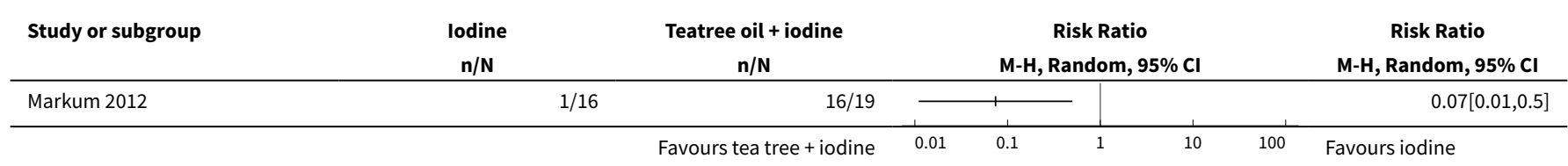

Analysis 21.2. Comparison 21 Topical: iodine versus tea tree oil combined with iodine, Outcome 2 Secondary outcome: improvement (up to 3 months after start of treatment).

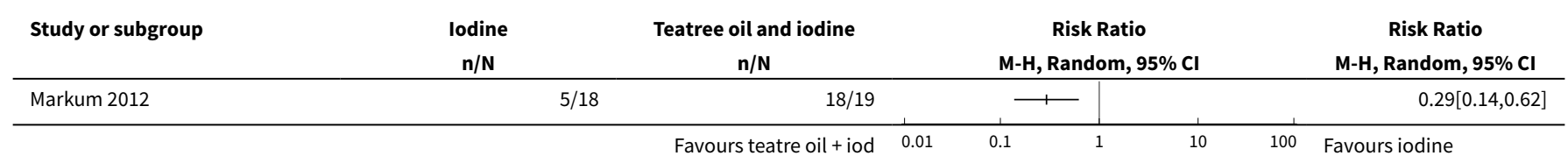

Comparison 22. Topical: tea tree oil versus tea tree oil combined with iodine

\begin{tabular}{|c|c|c|c|c|}
\hline Outcome or subgroup title & No. of studies & $\begin{array}{l}\text { No. of partici- } \\
\text { pants }\end{array}$ & Statistical method & Effect size \\
\hline $\begin{array}{l}1 \text { Primary outcome: short-term clinical cure } \\
\text { (up to } 3 \text { months after start of treatment) }\end{array}$ & 1 & & $\begin{array}{l}\text { Risk Ratio (M-H, Ran- } \\
\text { dom, } 95 \% \mathrm{Cl})\end{array}$ & $\begin{array}{l}\text { Totals not select- } \\
\text { ed }\end{array}$ \\
\hline $\begin{array}{l}2 \text { Secondary outcome: improvement (up to } 3 \\
\text { months after start of treatment) }\end{array}$ & 1 & & $\begin{array}{l}\text { Risk Ratio (M-H, Ran- } \\
\text { dom, } 95 \% \mathrm{CI})\end{array}$ & $\begin{array}{l}\text { Totals not select- } \\
\text { ed }\end{array}$ \\
\hline
\end{tabular}


Analysis 22.1. Comparison 22 Topical: tea tree oil versus tea tree oil combined with iodine, Outcome 1 Primary outcome: short-term clinical cure (up to 3 months after start of treatment).

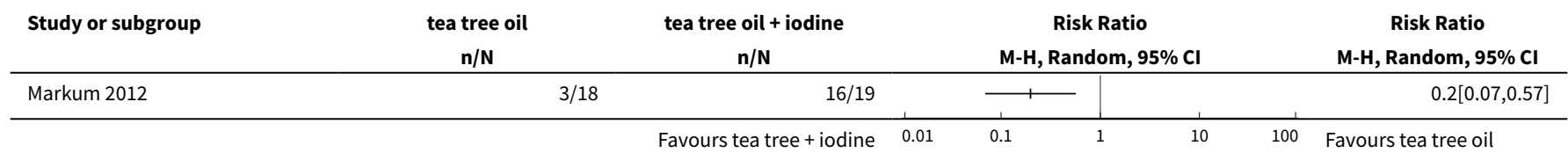

Analysis 22.2. Comparison 22 Topical: tea tree oil versus tea tree oil combined with iodine, Outcome 2 Secondary outcome: improvement (up to 3 months after start of treatment).

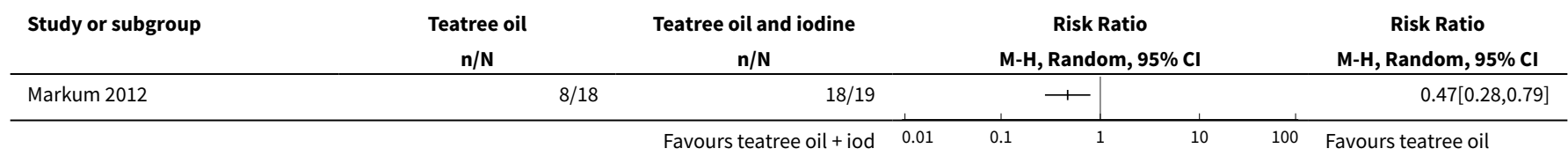

Comparison 23. Systemic: cimetidine versus placebo

\begin{tabular}{|c|c|c|c|c|}
\hline Outcome or subgroup title & No. of studies & $\begin{array}{l}\text { No. of partici- } \\
\text { pants }\end{array}$ & Statistical method & Effect size \\
\hline $\begin{array}{l}1 \text { Secondary outcome: medium-term clinical } \\
\text { cure (after } 3 \text { months and up to } 6 \text { months after } \\
\text { start of treatment) }\end{array}$ & 1 & & $\begin{array}{l}\text { Risk Ratio (M-H, } \\
\text { Random, 95\% Cl) }\end{array}$ & $\begin{array}{l}\text { Totals not select- } \\
\text { ed }\end{array}$ \\
\hline $\begin{array}{l}2 \text { Secondary outcome: medium-term improve- } \\
\text { ment (after } 3 \text { months and up to } 6 \text { months after } \\
\text { start of treatment) }\end{array}$ & 1 & & $\begin{array}{l}\text { Risk Ratio (M-H, } \\
\text { Random, 95\% Cl) }\end{array}$ & $\begin{array}{l}\text { Totals not select- } \\
\text { ed }\end{array}$ \\
\hline
\end{tabular}

Analysis 23.1. Comparison 23 Systemic: cimetidine versus placebo, Outcome 1 Secondary outcome: medium-term clinical cure (after 3 months and up to 6 months after start of treatment).

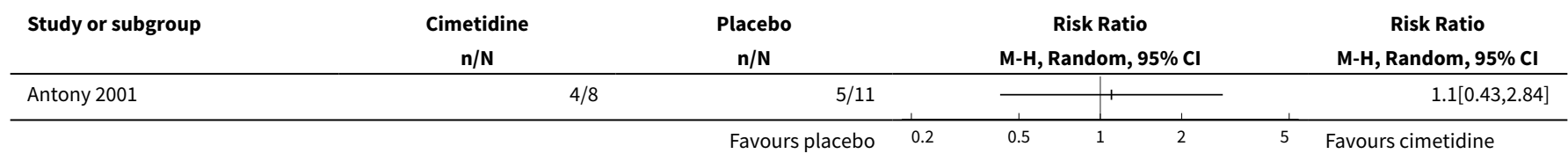

Analysis 23.2. Comparison 23 Systemic: cimetidine versus placebo, Outcome 2 Secondary outcome: medium-term improvement (after 3 months and up to 6 months after start of treatment).

\begin{tabular}{|c|c|c|c|c|c|c|}
\hline \multirow{2}{*}{$\begin{array}{l}\text { Study or subgroup } \\
\text { Antony } 2001\end{array}$} & $\begin{array}{c}\text { Cimetidine } \\
\mathrm{n} / \mathrm{N}\end{array}$ & $\begin{array}{c}\text { Placebo } \\
\mathbf{n} / \mathbf{N}\end{array}$ & & \multicolumn{2}{|c|}{$\begin{array}{c}\text { Risk Ratio } \\
\text { M-H, Random, } 95 \% \mathrm{CI}\end{array}$} & \multirow{2}{*}{\begin{tabular}{c}
\multicolumn{1}{c}{ Risk Ratio } \\
M-H, Random, 95\% Cl \\
$1.07[0.73,1.57]$
\end{tabular}} \\
\hline & $7 / 8$ & $9 / 11$ & & & 1 & \\
\hline
\end{tabular}


Comparison 24. Systemic: calcarea carbonica versus placebo

\begin{tabular}{lllll}
\hline Outcome or subgroup title & No. of studies & $\begin{array}{l}\text { No. of partici- } \\
\text { pants }\end{array}$ & Statistical method & Effect size \\
\hline $\begin{array}{l}1 \text { Primary outcome: short-term clinical cure } \\
\text { (up to } 3 \text { months after start of treatment) }\end{array}$ & 1 & & $\begin{array}{l}\text { Risk Ratio (M-H, Ran- } \\
\text { dom, } 95 \% \mathrm{Cl})\end{array}$ & $\begin{array}{l}\text { Totals not select- } \\
\text { ed }\end{array}$ \\
\hline
\end{tabular}

Analysis 24.1. Comparison 24 Systemic: calcarea carbonica versus placebo, Outcome 1 Primary outcome: short-term clinical cure (up to 3 months after start of treatment).

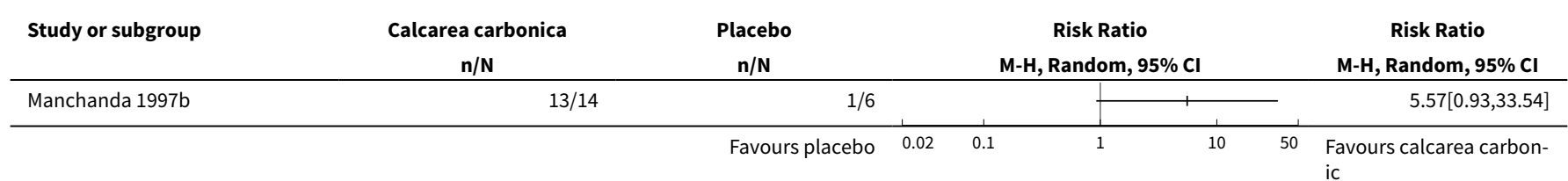

\section{ADDITIONAL TABLES}

Table 1. Treatment modalities and examples of references

\begin{tabular}{|c|c|c|c|}
\hline Treatment class & Treatment modality & Included studies & Other studies \\
\hline \multirow[t]{2}{*}{ 'Doing nothing' } & Awaiting natural resolution & - & Olsen 2015; Takemura 1983 \\
\hline & Placebo & $\begin{array}{l}\text { Antony 2001; Eichenfield } \\
\text { 2005; Manchanda 1997b; } \\
\text { Paller 2005a; Paller 2005b }\end{array}$ & - \\
\hline \multirow[t]{7}{*}{ Surgical treatments } & Cryotherapy & Al-Mutairi 2010 & $\begin{array}{l}\text { Barton 2002; Caballero 1996; Sal- } \\
\text { manpour } 2006\end{array}$ \\
\hline & Curettage & Hanna 2006; Machado 2010 & de Waard 1990; Simonart 2008 \\
\hline & Curettage with punch & - & Quan 2000 \\
\hline & Electric cauterisation & - & He 2001 \\
\hline & Physical expression (squeezing) & - & Weller 1999 \\
\hline & Pricking & - & Wishart 1903 \\
\hline & Pulsed dye laser & - & Hammes 2001 \\
\hline \multirow[t]{4}{*}{ Topical treatments } & Acidified nitrite & Ormerod 1999 & Gräfe 2000 \\
\hline & Adapalene & - & Scheinfeld 2007 \\
\hline & Australian lemon myrtle oil & Burke 2004 & - \\
\hline & Benzoyl peroxide & Saryazdi 2004 & - \\
\hline
\end{tabular}


Table 1. Treatment modalities and examples of references (Continued)

\begin{tabular}{|c|c|c|}
\hline Bromogeramine & - & He 2001 \\
\hline Cantharidin & $\begin{array}{l}\text { Coloe Dosal 2014; Hanna } \\
2006\end{array}$ & $\begin{array}{l}\text { Funt 1961; Funt 1979; Ross 2004; Sil- } \\
\text { verberg } 2000\end{array}$ \\
\hline Cidofovir & - & $\begin{array}{l}\text { Davies 1999; Toro 2000; Zabawski } \\
1999\end{array}$ \\
\hline Diphencyprone & - & Kang 2005; Kyu 1993 \\
\hline Griseofulvin & - & Salmanpour 2006 \\
\hline Honey & - & Holt 2015 \\
\hline Hydrogen peroxide cream & - & Bigardi 2003; Semkova 2014 \\
\hline Hyperthermia & - & Gao 2016 \\
\hline Imiquimod & $\begin{array}{l}\text { Al-Mutairi 2010; Eichenfield } \\
\text { 2005; Hanna 2006; Paller } \\
\text { 2005a; Paller 2005b; Seo } \\
\text { 2010; Theos } 2004\end{array}$ & $\begin{array}{l}\text { Arican 2006; Barba 2001; Bayerl } \\
\text { 2003; Hengge 2003; Lim 2003; Lio- } \\
\text { ta 2000; Metkar 2008; Skinner 2000; } \\
\text { Skinner 2002; Syed } 1998\end{array}$ \\
\hline lodine & Markum 2012 & - \\
\hline lodine combined with tea tree oil & Markum 2012 & - \\
\hline Milkweed & - & Behl 1970 \\
\hline Povidone iodine plus salicylic acid & $\begin{array}{l}\text { Markum 2012; Ohkuma } \\
1990\end{array}$ & - \\
\hline Phenol & Leslie 2005 & Weller 1999 \\
\hline Podophyllotoxin (HIV patients) & - & $\begin{array}{l}\text { Markos 2001; Syed 1994; Teil- } \\
\text { la-Hamel 1996 }\end{array}$ \\
\hline Potassium hydroxide & $\begin{array}{l}\text { Bazza 2007; Machado 2010; } \\
\text { Seo 2010; Short 2006; Uç- } \\
\text { mak } 2013\end{array}$ & $\begin{array}{l}\text { Metkar 2008; Romiti 1999; Romiti } \\
2000\end{array}$ \\
\hline Retinoic acid & - & Hund 1975 \\
\hline Salicylic acid & $\begin{array}{l}\text { Hanna 2006; Leslie 2005; } \\
\text { Ohkuma } 1990\end{array}$ & - \\
\hline Salicylic acid combined with lactic acid & Machado 2010 & - \\
\hline $\begin{array}{l}\text { Salicylic acid combined with sodium } \\
\text { nitrite }\end{array}$ & Ormerod 1999 & - \\
\hline Silver nitrate & - & Niizeki 1999 \\
\hline Tea tree oil & Markum 2012 & - \\
\hline Tretinoin & Saryazdi 2004 & - \\
\hline
\end{tabular}


Table 1. Treatment modalities and examples of references (Continued)
Yellow oxide of mercury
Davis 1896

\begin{tabular}{llll}
\hline $\begin{array}{l}\text { Systemic treat- } \\
\text { ments }\end{array}$ & Cimetidine & Antony 2001 & $\begin{array}{l}\text { Cunningham 1998; Dohil 1996; Shar- } \\
\text { ma 1998; Yasher 1999 }\end{array}$ \\
\cline { 2 - 4 } & Calcarea carbonica (homeopathy) & Manchanda 1997b & Manchanda 1997a \\
\cline { 2 - 4 } & Griseofulvin & - & Singh 1977 \\
\hline $\begin{array}{l}\text { Combinations of } \\
\text { above }\end{array}$ & Potassium iodide followed by X-rays & - & Cope 1915 \\
\hline
\end{tabular}

\section{A P P E N DICES}

\section{Appendix 1. Cochrane Skin Group Specialised Register (CRS) search strategy}

"mollusc* contagios*" or "water wart*"

\section{Appendix 2. CENTRAL (Cochrane Library) search strategy}

$\# 1 \mathrm{MeSH}$ descriptor: [Molluscum Contagiosum] explode all trees

$\# 2$ mollusc $^{\star}$ contagios $^{\star}: \mathrm{ti}, \mathrm{ab}, \mathrm{kw}$

\#3 water wart*:ti,ab,kw

$\# 4$ \{or \#1-\#3\}

\section{Appendix 3. MEDLINE (Ovid) search strategy}

1. Molluscum Contagiosum/

2. mollusc $\$$ contagios $\$ . m p$.

3. water wart\$.mp.

4. or/1-3

5. randomized controlled trial.pt.

6. controlled clinical trial.pt.

7. randomized.ab.

8. placebo.ab.

9. clinical trials as topic.sh.

10. randomly.ab.

11. trial.ti.

12.5 or 6 or 7 or 8 or 9 or 10 or 11

13. exp animals/ not humans.sh.

14. 12 not 13

15. 4 and 14

[Lines 5-14: Cochrane Highly Sensitive Search Strategy for identifying randomized trials in MEDLINE: sensitivity-and precision-maximizing version (2008 revision)]

\section{Appendix 4. Embase (Ovid) search strategy}

1. crossover procedure.sh.

2. double-blind procedure.sh.

3. single-blind procedure.sh.

4. (crossover\$ or cross over\$).tw.

5. placebo\$.tw.

6. (doubl\$ adj blind\$).tw.

7. allocat\$.tw.

8. trial.ti.

9. randomized controlled trial.sh.

10. random\$.tw. 
11. or/1-10

12. exp animal/ or exp invertebrate/ or animal experiment/ or animal model/ or animal tissue/ or animal cell/ or nonhuman/

13. human/ or normal human/

14. 12 and 13

15. 12 not 14

16. 11 not 15

17. molluscum contagiosum/

18. mollusc \$ contagios\$.mp.

19. water wart\$.mp.

20. or/17-19

21.16 and 20

\section{Appendix 5. LILACS search strategy}

(mollusc\$ contagios\$) or (molusco contagioso)

In LILACS we searched using the Controlled clinical trials topic-specific query filter and the terms above.

\section{WHAT'S NEW}

\begin{tabular}{lll}
\hline Date & Event & Description \\
\hline 21 July 2016 & New search has been performed & $\begin{array}{l}\text { A new search led to the addition of 11 new included studies, and } \\
\text { we updated the review in line with MECIR standards. }\end{array}$ \\
\hline 21 July 2016 & $\begin{array}{l}\text { New citation required and conclusions } \\
\text { have changed }\end{array}$ & New evidence added regarding the use of topical imiquimod \\
\hline
\end{tabular}

\section{H I S T O R Y}

Protocol first published: Issue 2, 2004

Review first published: Issue 2, 2006

\begin{tabular}{lll}
\hline Date & Event & Description \\
\hline 7 March 2012 & Amended & The lead author's contact details have been updated. \\
\hline 7 December 2009 & Amended & $\begin{array}{l}\text { Unpublished data (Short 2002) has now been published as Short } \\
\text { 2006. }\end{array}$ \\
\hline 22 July 2009 & New search has been performed & $\begin{array}{l}\text { New search, 6 new trials added. 'Risk of bias' table added, Dis- } \\
\text { cussion rearranged, various minor adaptations. }\end{array}$ \\
\hline 21 June 2008 & Amended & Converted to new review format \\
\hline 6 December 2005 & $\begin{array}{l}\text { New citation required and conclusions } \\
\text { have changed }\end{array}$ & Substantive amendment \\
\hline
\end{tabular}

\section{CONTRIBUTIONS OF AUTHORS}

JCvdW was the contact person with the editorial base, co-ordinated contributions from the coauthors, and wrote the final draft of the review.

SK, EJK, RvdS, and JCvdW screened papers against the eligibility criteria.

JCvdW obtained data on ongoing and unpublished studies.

SK, EJK, RvdS, and JCvdW appraised the quality of papers. 
SK, EJK, RvdS, and JCvdW extracted data for the review and sought additional information about papers.

JCVdW and EJK entered data into Review Manager 5.

JCvdW and EJK analysed and interpreted data.

JCvdW worked on the Methods section.

All review authors commented on draft versions of this update.

SK drafted the clinical sections of the Background and responded to the clinical comments of the referees.

$\mathrm{JCvdW}$ responded to the methodology and statistics comments of the referees.

AS was the consumer coauthor and checked the review for readability and clarity, as well as ensuring outcomes were relevant to consumers.

$\mathrm{JCvdW}$ is the guarantor of the update.

\section{Disclaimer}

This project was supported by the National Institute for Health Research, via Cochrane Infrastructure funding to the Cochrane Skin Group. The views and opinions expressed therein are those of the authors and do not necessarily reflect those of the Systematic Reviews Programme, NIHR, NHS or the Department of Health.

\section{DECLARATIONS OF INTEREST}

Johannes $C$ van der Wouden: My institution has received money from the following non-profit sources which have no real or potential vested interest in the findings of this Cochrane review: Editorial Board, Huisarts en Wetenschap (monthly journal of Dutch College of GPs); Advisory Board of Achmea Health Database (health insurance company). The funds did not come from sources that produce any of the drugs that might be included in the review or competitors to the drugs in the review.

Renske van der Sande: nothing to declare.

Emma J Kruithof: nothing to declare.

Annet Sollie: nothing to declare.

Lisette WA van Suijlekom-Smit: I have received a travel grant from Pfizer (American College of Rheumatology Annual Meeting 2014 Boston). Sander Koning: nothing to declare.

\section{SOURCES OF SUPPORT}

\section{Internal sources}

- Department of General Practice, Erasmus MC, Rotterdam, Netherlands. in kind support

- Department of General Practice and Elderly Care Medicine, VUmc University Medical Center, Amsterdam, Netherlands. in kind support

\section{External sources}

- The National Institute for Health Research (NIHR), UK.

The NIHR, UK, is the largest single funder of the Cochrane Skin Group.

\section{DIFFERENCES BETWEEN PROTOCOLANDREVIEW}

The title of the published protocol was inadvertently left as 'Interventions for molluscum contagiosum in children', although a decision had been made not to restrict the review to children.

\section{Differences between the protocol and the current update}

For differences between other published versions, please see the 'Differences between protocol and review' sections within the original publications.

Objectives: In the protocol, we had planned to assess the effects of treatments, but in this and the previous updates we broadened this to include management strategies because waiting for natural resolution is a recognised option for dealing with molluscum contagiosum. We amended the text from that which was in the protocol to make our objectives more clear.

Types of studies: In the protocol, we said that "studies should compare one or more treatments with another, with placebo, or with no treatment (waiting for natural response)"; we removed this sentence in this and previous updates because it refers to comparisons rather than studies. 
Types of interventions: We had planned to include randomised trials of all treatments for molluscum contagiosum, but narrowed this to include only treatments aimed at eradicating molluscum contagiosum lesions, and excluded studies on other aspects of the treatment of molluscum contagiosum, for example on reducing pain in the studies that assessed the effect of using an analgesic EMLA (eutectic mixture of local anaesthetics) cream before the actual intervention took place. This was because the analgesic was not used to eradicate the molluscum lesions.

Primary outcomes: We decided that our original choice for 'short-term clinical cure' of one month was not realistic, and therefore changed it to three months. We have also clarified our primary outcome to make it more manageable: short-term clinical cure (up to three months after treatment). (Please see Overall completeness and applicability of evidence for a more detailed description of why we felt the original choice was not realistic.) We also deleted the term 'elevated' in the description, as we felt it was unnecessary and could possibly cause confusion, the implication being that there are elevated and non-elevated forms of the lesion.

Where included studies used the term 'complete clearance' or 'free of lesions' or 'cured or $>90 \%$ cleared', we classed these as our primary outcome 'short-term clinical cure (up to three months after start of treatment)' or our secondary outcome 'medium- and long-term cure (after three months and up to six months, and after six months, respectively)'. Where studies have referred to 'partial clearance', we took this to mean our secondary outcome 'improvement'.

Secondary outcomes: We did not initially specify the outcome 'disease-related quality of life' in the protocol, but added it afterwards as we considered it to be a relevant additional measure.

We also added 'short-, medium-, and long-term improvement (including cure, intervals as above)' as a secondary outcome as we considered it to be important. For this outcome we combined 'improvement' and 'cure' (even though cure alone was a seperate outcome) because 'improvement' would be hard to interpret without also including those who were cured. For example: suppose in group A, 30\% were cured and another $20 \%$ improved. In group B, $40 \%$ were cured and $10 \%$ improved. Comparing improvement rates between A and B (20\% versus $10 \%)$ is misleading, whereas combining cure and improvement ( $50 \%$ versus $50 \%)$ is not.

Electronic searches: We expanded the number of trial registries that we planned to search when we became aware of the existence of these registries and in line with current Cochrane Skin practices. For similar reasons, we added Google as an additional electronic search strategy.

Selection of studies: If a randomised controlled trial included a variety of skin diseases, of which one was molluscum contagiosum, the number of molluscum participants needed to be at least five in the active treatment and placebo groups in order to reduce the role of extremely small studies. We added this criterion after the protocol was approved when we found a study that included 10 molluscum participants with a 9:1 distribution over the two treatment groups (Caballero 1996). The criterion also applied to Manchanda 1997 .

Selection of studies: If the setting of the study was not explicitly mentioned in the text, we assumed it to be carried out at the affiliation of the first author. Also, if the full text of a study was not available, we considered published abstracts for this update, as we have done this for previous versions of the review.

Assessment of risk of bias in included studies: In this update, we assessed each study using Cochrane's 'Risk of bias' tool (Higgins 2011), as this is now required. Also items (5), (6) and (7), which differed from the original protocol or were absent, were added or amended for the 2009 update as recommended. In previous versions of this review, items (3) and (4) were combined. For the 2016 update we further clarified how we decided what constituted an 'adequate' assessment and therefore low risk of bias.

Measures of treatment effect: Following the recent Cochrane Skin Group recommendations, we decided post hoc to re-analyse results from individual studies with borderline significance and with low numbers of events (fewer than 10 in total) or a total sample size of less than 30 , using Fisher's exact test. The resulting $P$ value was leading in interpreting the results.

Data synthesis: We had planned to express dichotomous results as odds ratios, but changed this to risk ratios and as a number needed to treat where appropriate because these are easier for most readers to understand. We decided to report numbers needed to treat only for comparisons with more than one study and only in the case of statistically significant differences, the latter because numbers needed to treat for differences that are statistically not significant produce large and uncertain confidence intervals.

When the same comparison between two interventions was made in more than one study, and studies appeared to have been executed in similar groups and settings, we planned to use statistical tests for homogeneity between studies. In those studies where the available data were sufficiently homogenous and where a pooled estimate of the treatment effect made sense, we planned to conduct a meta-analysis. However, we could not implement these plans in most cases due to lack of data.

Assessment of reporting biases: Subsequent to the protocol, we aimed to assess reporting bias by comparing the published trial publications with the study protocol, but no protocols were available.

Unit of analysis issues: In our methods we planned to use special analytic techniques for paired (split-body) designs; however, we were unable to do this as the paired data were not available to us. 
Dealing with missing data: Although this was not specified in the protocol, we considered participants who dropped out or were lost to follow-up as treatment failures.

Unit of analysis issues/Assessment of heterogeneity/Sensitivity analysis: We had planned analyses not documented in the protocol, including the use of sensitivity analyses to examine the effects of excluding studies with lower reported methodological quality, as well as how to analyse cross-over trials and within-participant designed trials. However, we did not undertake these analyses because of the small number of studies for each comparison.

Sensitivity analysis: We planned to use sensitivity analyses to examine the effects of excluding studies with high risk of bias. However, we did not undertake these analyses because of the small number of studies for each comparison.

Summary of findings: We developed 'Summary of findings' tables subsequent to our protocol. We have produced one for this update.

Quality of evidence: We used GRADE to assess the quality of evidence for each primary outcome and key secondary outcomes.

\section{NDEX TERMS}

\section{Medical Subject Headings (MeSH)}

Adjuvants, Immunologic [therapeutic use]; Aminoquinolines [therapeutic use]; Anti-Infective Agents, Local [therapeutic use]; Benzoyl Peroxide [therapeutic use]; Cimetidine [therapeutic use]; Hydroxides [therapeutic use]; Imiquimod; Molluscum Contagiosum [drug therapy] ["therapy]; Myrtus; Olive Oil [therapeutic use]; Phytotherapy [methods]; Plant Oils [therapeutic use]; Potassium Compounds [therapeutic use]; Povidone-lodine [therapeutic use]; Randomized Controlled Trials as Topic; Remission, Spontaneous; Salicylic Acid [therapeutic use]; Sodium Nitrite [therapeutic use]

\section{MeSH check words}

Humans 